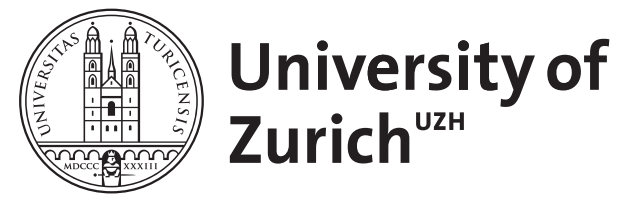

Zurich Open Repository and Archive

University of Zurich

University Library

Strickhofstrasse 39

CH-8057 Zurich

www.zora.uzh.ch

Year: 2020

\title{
Pre-Buddhist" Conceptions of Vision and Visuality in China and Their Traces in Early Reflections on Painting
}

\author{
Suter, Rafael
}

Posted at the Zurich Open Repository and Archive, University of Zurich

ZORA URL: https://doi.org/10.5167/uzh-206482

Journal Article

Published Version

Originally published at:

Suter, Rafael (2020). Pre-Buddhist" Conceptions of Vision and Visuality in China and Their Traces in Early Reflections on Painting. Asiatische Studien / Études Asiatiques, 74(4):1013-1079. 


\title{
Rafael Suter* \\ "Pre-Buddhist" Conceptions of Vision and Visuality in China and Their Traces in Early Reflections on Painting
}

\author{
https://doi.org/10.1515/asia-2020-0022
}

\begin{abstract}
This paper attempts to delineate the relation of early Chinese views on vision and visuality to nascent reflections on painting arising in the Early Medieval period. Ever since that time, pictorial creativity has been associated with Buddhist ideas of spiritual perfection. Likewise, the Early Medieval concern for the visualization of spiritual journeys to exceptional humans (and superhumans) through imaginary landscapes seems to be of Buddhist origin. The first part of this paper gives a short sketch of the intellectual landscape in which theorizing on painting since the 5th century CE first arose. The main body of the study, consisting of parts two through five, close readings of pre-Buddhist texts on vision and imagination. From these exploratory investigations it emerges that the very terms that are key in early reflections on painting such as 'spirit' (shen 神), 'perspicacity' (ming 明), but also 'imagination' (xiang 想) and 'symbol' (xiang 象) are closely related to a specific conception of seeing and visuality which is manifest in these texts. A final part sketches the possible relevance of these observations in early and pre-imperial sources for the interpretation of Chinese theories on painting. It emerges that while the rising interest in imagination since the Eastern Jin period is indeed an innovation inspired by Buddhism, the extraordinary role of the notion of 'spirit' in reflections about painting is closely related to earlier autochthonous traditions. The appeal to specifically Buddhist notions such as the samādhi of free play in texts on pictorial production and contemplation appears to be of a secondary character. It seems to be mediated by the inclusion of the very word 'spirit' (shen) into Chinese renderings of technical Buddhist terms related to meditation, which resulted in the implicit association of this specialist vocabulary with inherited conceptions of spirit as a luminous force animating, inspiring and enlightening things, in both quite a literal and in a rather metaphorical sense.
\end{abstract}

Keywords: seeing, imagination, spirit (shen), Chinese Landscape Painting (shan shui), early Chinese Cosmology and Gnoseology of Light, Jia Yi (c. 201-169 BCE)

\footnotetext{
*Corresponding author: Rafael Suter, University of Zurich, Institute of Asian and Oriental Studies, Zürichbergstrasse 4, 8032 Zürich, Switzerland,

E-mail: rafael.suter@access.uzh.ch
} 
The following words are taken from a passage of a collection of colophons on famous paintings and painters accomplished, in the 1120s, by the Northern Song scholar Dong You 董占. His portrait of the eminent landscapist Li Cheng 李成 (Xianxi 咸熙, 919-967) not only brings us to this leading genre in Chinese painting but also illustrates a way of conceiving creativity that is symptomatic for Chinese discourses on artistic production:

Xie He (fl. 499-502) says that what is most difficult in painting is to draw truthfully ${ }^{1}$, and Gu Kaizhi (346-407) thinks that it all depends on adding the last stroke to the (position of the) eyeball; thus he states that conveying (a person's) spirit and depicting (their) aura depends precisely on this. When our contemporaries discuss painting, they all miss the intention of the ancients, they don't know mountains and rivers, grasses and trees, small animals and fish, birds and quadrupeds. But who would negate their genuine character?! If one misses the similarities of their shapes, then one paints a tiger, but it is a dog. Could one then say that one captures its genuine character? Mr. Li Yingqiu, styled Xianxi, displayed utmost clarity. Hence, when he delved into painting, he subtly entered the samädhi. He arrived at the point where there was no line or trace to follow and where one didn't know the spot where he would lower the brush [next]. Therefore, he was able to be without any external contamination (lit. "a whiff of dust”), and in his detachment from other people he did not concentrate on accurately shaping mountains, waters, trees, stones, smoke, fog, peaks and mist. Rather, he penetrated into the movement of their natural (lit. "heavenly") impulses, so that the bright places opened and the dark ones were closed. His spontaneous inspiration was unpredictable and his contemporaries did not succeed to understand it. Therefore, they said: The breath is raised by the brush, the brush is left by the images. And when he engaged in painting he completely forgot the painting. Such was the adequacy of his shapes! This is not due to his attaining some kind of subtle understanding, but due to his never abandoning this [i.e. his spontaneous reaction to their impulses]. (“On Li Yingqiu's Paintings of Mountains and Water”書李營丘山 水圖, Collected Colophons of Guangchuan 廣川畫跋).

謝赫言畫者寫真㝡難 ${ }^{2}$ 而顧凱之 ${ }^{3}$ 則以為都在點睛處, 故謂傳神寫照 ${ }^{4}$, 正在阿堵中爾。世人論 畫都失古人意, 不知山水草木蟲魚鳥獸。孰非其真者邪。荷失形似, 便是畫虎而狗者。可論 得其真哉! 營丘李咸熙士流清放者也。故於畫妙入三昧, 至於無蹊轍可, 求亦不知下筆 | 處,

1 The phrase "xie zhen" is later used in the specific sense of portrait painting.

2 While I was unable to identify this or a similar claim attributed to Xie He, Zhang Yanyuan 張彥遠 (815-907) in his Records of Famous Paintings of Successive Dynasties (Lidai minghua ji 歷代名畫記, comp. 847 CE) mentions a very similar statement by Gu Kaizhi 顧愷之 (346-407): “顧愷之曰: 「畫人最難, 次山水, 次狗馬, 其臺閣, 一定器耳, 差易為也。” ““Gu Kaizhi says that painting humans is most difficult. Next come mountains and waters, and then dogs and horses. The making of terraces and pavilions or specific tools is far more easier." Lidai minghua ji, p. 290).

3 This is an obvious mistake for 顧愷之.

4 Quoted in Lidai minghua ji, j. 5, p. 319. Cf. Cai 2004: 315 who renders it " $[\mathrm{t}] \mathrm{o}$ convey the spirit and give a vivid portrayal". 
故能無蓬塊氣, 其絕人處不在得真形山水木石煙霞嵐霧。間其天機之動, 陽開陰闔。迅發警 絕, 世不得而知也。故曰: 氣生於筆, 筆遺於象。夫為畫而至忘畫者。是其形之適哉! 非得於 妙解者, 未有遺此者也。 5

When he addresses the question of how a painter has to capture the shapes of mountains, rivers, plants, animals and other things, Dong first quotes $\mathrm{Gu}$ Kaizhi 顧愷之 (344-405) and Xie He 謝赫 (fl. 479-501), two Early Medieval authors whose reflections about painting are among the earliest extant texts on the subject. Dong contrasts their common emphasis on the crucial role of the accurate depiction' (xie zhen 寫真) of things to Li Cheng: When Li painted his landscapes, he used to completely forget what he was painting. Purely spontaneous, his painting was unpredictable for himself and inscrutable for outside observers. For them, it seemed as if the lines drew the brush rather than the other way round.

Such artistic perfection is captured by a term borrowed from Buddhist meditation: By the time of Dong, it had become a literary cliche to capture the concentration of the artist in terms of religious meditation. More specifically, the act of spontaneous creation in Chinese art, painting just as well as poetry, had been analogized to the spiritual powers of a Buddha or bodhisattva in the 'samādhi of the free play' (youxi sanmei 遊戲三昧). Like these religious virtuosi, who in this state of highest concentration gained power over the causality of karmic retribution and thus could act in absolute freedom, the landscapist arranges his scenery without the need to slavishly follow the model of the real landscape before his eyes: Creativity in art finds its model in an image of religious omnipotence.

Even at the core of reflections on landscape painting, which Sullivan (1916-2013) once provocatively identified as a "wholly native art", allegedly rather hindered than fostered by the growing influence of Buddhism in Medieval China, ${ }^{6}$ we thus find a key concept of explicitly Buddhist pedigree. ${ }^{7}$

5 Guangchuan huaba, pp. 477-478.

6 Sullivan 1962: 78, qtd. in Loehr 1962: 259.

7 The florescence of painting since the Six Dynasties period has early been related to Buddhist influence. Thus, the so-called "six laws" of painting transmitted by Xie He, the earliest witness of systematic attempts of painting criticism in Chinese, had been associated with the Indian theory of the "six limbs" by William Acker (Bush 1983: 143) at latest, and Victor Mair has erected a philological bulwark in support of the thesis that not only the "six principles" were adopted from India, but they were grossly misunderstood by Chinese readers of Xie for roughly a millennium (see Mair 2004). In spite of an impressive amount of materials that render a cultural transfer from India highly plausible, the argument itself ultimately remains inconclusive, not least due to the difficulty to identify a definite Indian source - be it a work or a milieu - as a possible origin. The argument also seems to run circle when Mair invokes a text by the Song dynasty critic Liu Daochun 劉道醇 $(f l$. 1057) - who, based on his own hypothesis, must have been ignorant of the genuine meaning of the "six laws" - as a witness for his thesis (p. 107). 
The conviction that this most appreciated genre of Chinese painting indeed arose from a Daoist, that is, quintessentially Chinese, context even had earned it the label of "landscape Taoism". 8 That this is a gross oversimplification, at best, has been pointed out by Bush, who has instead emphasized the role of the lay Buddhism of Zong Bing 宗炳 (375-443), another early author of reflections about landscape painting, ${ }^{9}$ tentatively suggesting the term "landscape Buddhism"10 for Zong's specific approach to views of mountains and waters. ${ }^{11}$ Meanwhile, it seems to be commonly acknowledged that Chinese landscape painting has resulted from a "hybridization" and "cross-fertilization of Taoism and Buddhism on Chinese soil". ${ }^{12}$ In a recent study on visualization and imagination during the Eastern Jin period (317-420), Tian Xiaofei has demonstrated in detail the close interconnection between the imagination and depiction of landscapes with the visualization of "transcendent figures". ${ }^{13}$ She even identified a typical

8 de Bary et al. 1983: 292; Bush 1983: 132; Bush 2004: 76. On the shift of attention from a general quest of naturalness and spontaneity to the specific concern with landscape in the Early Medieval Daoism of the so-called "Seven Sages of the Bamboo Grove" see Shaw 1988: 188-189.

9 Miranda Shaw credits him with the invention of landscape painting in the proper sense of the word, as it was only with him that the landscape itself became the main concern of painting. With earlier painters like the above-mentioned Gu Kaizhi landscape according to her mainly "provides a setting for a legendary plot” (Shaw 1988: 193; 200). Yet, like Susan Bush (1983: 133), Shaw emphasizes the meditative rather than aesthetic function of Zong's landscape painting (Shaw 1988: 194). For an overview on English translations of his seminal Preface to painting mountains and waters (Hua shan shui xu 畫山水序), see, e.g. Bush 1983: 140.

10 Bush 2004: 60-61. Bush admits that both labels, which she uses for contrasting Zong Bing from his coeval Wang Wei 王微 (415-453), author of another early text on Chinese landscape painting, namely "landscape Buddhism” vs. "Neo-Daois[m]" and "landscape Daoism”, while "perhaps too simplistic to characterize the content of their essays" (Bush 2004: 61), are still useful in referring to their fundamentally distinct intellectual and social backgrounds. For the history and problematic character of the term "Neo-Daoism" going back to Paul Pelliot (1878-1940) see Espesset 2018: 1066, n. 26; 1073: n. 57.

11 For the relation of the painting of mountains and waters to explicitly religious representations of paradise landscapes with the constituent elements of a main mountain raising from water see Ledderose 1983, esp. p. 175. "It might appear that to a larger extent and in a more concrete sense than generally recognized, landscape painting in China is the representation of an earthly paradise." (Ledderose 1983: 180).

12 Shaw 1988: 183. Cf. also Turner 2009: 110-111.

13 On the mountains as the homes of spirits and immortals in Ge Hong's Daoism see Shaw 1988: 187: "Ko Hung lists twenty-eight mountains [...] of [...] heightened numinosity. He explains that these mountains are the homes of spirits and immortals who can aid, bless, and instruct the immortality-seeking mountaineer." 
"configuration" in poems ${ }^{14}$ which proceed from the description of a landscape to the appearance therein of a human figure ${ }^{15}$ - "literally the 'spirit,' 'soul,' or 'god' (shen) of the mountain" ${ }^{16}$ - whose detection by the observer symbolizes the achievement of transcendence. ${ }^{17}$ As she notes with respect to a $f u$ 賦 by Sun Chuo 孫綽 (314-371) about a journey to Mount Tiantai 天台, poets seem to have used visual images as an aid for envisioning the mountains onto which their imaginary pilgrimages led them ${ }^{18}$ - a situation strongly reminiscent of Zong Bing, whose imaginary roaming through the mountains depicted on the paintings in his home was essentially a substitute that enabled him to seek communion with the sages and worthies, although his physical constitution - age and sickness - no more allowed him to wander through the real mountains. ${ }^{19}$ To whatever extent the formation of landscape painting was indeed influenced by Buddhism - it is clearly related to the sudden prominence of practices of visualization and imagination, not least of human figures, from the early 4th century CE onwards. This development is reflected in the emergence and rapid spread of the character xiang 想 that is doubtlessly spurred by the new 'religion of images' (xiangjiao 像教 ${ }^{20,21}$. Far from being a peculiarity of two individual authors, the sequence of

14 Frodsham (1960/1) has discussed Zong Bing's essay in conjunction with the poetical appreciation of landscape scenery in the fourth and fifth centuries (Bush 1983: 132). Bush explicitly relates his alleged “landscape Buddhism” with the poet Xie Lingyun 謝靈運 (385-433) (p. 133). For this increasing importance of landscape in poetry see also Shaw 1988: 189-190.

15 Tian 2005: 87.

16 Tian 2005: 88. Shaw points out that "visualisation of spirits and immortals" has been "an important aspect of Taoist practice for many groups" long before the invention of landscape poetry and painting (Shaw 1988: 193).

17 Tian 2005: 88.

18 Tian 2005: 86. “The reference to 'pictures and illustrations' appears to indicate that Sun Chuo was using visual images as an aid in his envisioning of the mountain. Although the $f u$ itself describes in great detail the author's 'ascent,' the framework was established at the very beginning: it is a spiritual, not physical, pilgrimage.”

19 Cf. Tian 2005: 91.

20 Eric M. Greene (2018) has recently cautioned against uncritical interpretations of this term. He points out that the understanding of xiangjiao in the sense of a "religion of images" only arises in anti-Buddhist polemical texts in the late 5th c. CE (p. 458). Before that time, the veneration of images does not seem to have been understood as specifically Buddhist. Greene moreover refers to Paul Pelliot, who had shown early in the 1930s that the expression xiangiiao has a specifically eschatological meaning that denotes the era of the "semblance of teachings", a period of decline of the dharma allegedly setting in some 500 years after the Buddha's demise (p. 457). Even if the sudden appearance of image worship from the late 2nd c. CE onwards thus suggests that it was indeed inspired by Buddhism, the interpretation of xiangiao as a "religion of images" seems distinctively late.

21 Tian 2005: 90. Bush thinks it possible that Zong Bing's approach to landscape painting was "conditioned" by "Buddhist attitudes toward icons, since he considered painted scenery to be as 
an initial phase of contemplation and an ensuing imaginary journey attested both in Sun Chuo's composition and in Zong Bing's text on painting, turns out to be an essential characteristic of the medieval conception of artistic production, as the works of the literary critics Lu Ji 陸機 (261-303) and Liu Xie 劉妿 (c. 465-522) show: The former refers to the initial contemplation as "retaining one's sight and countervailing one's listening” (shou shi fan ting 收視反聽) ${ }^{22}$, the latter speaks of a “state of silence and mental concentration" (jiran ning lü 寂然凝慮) ${ }^{23}$. And while neither is an explicit reference to the kind of imagination under consideration here, both formulations suggest an intentional disconnection from outside sensual impressions and a retreat into the inside that set the stage for imagination. ${ }^{24}$ Indeed, this static phase of concentration is followed by a " $\mathrm{dy}$ namic flight of imagination" 25 that "starts off with the well-concentrated jing or vital essence, goes through the entire spectrum of temporality, and reaches the ultimate ends in all directions". ${ }^{26}$ Cai Zong-qi notes the similarity, "if not identi [ty]" 27 of these two "major phases of literary production" with meditational practices of "concentrating” one's "vital essence" and "entering one's shen". ${ }^{28}$ Related expressions in pre-medieval sources such as 'to enter the shen' in the Xici 繫辭 (Appended Statements of the Changes of Zhou) according to him point to an integration of the human shen with "the cosmic shen or miraculous modus

effective an aid in meditation as natural landscape" (Bush 1983: 137). Miranda Shaw more specifically holds that Zong Bing's portrayal of landscape shares the function of the Buddha-image in meditative invocations of Buddha Amitābha as practiced by Huiyuan 慧遠 (334-416) and his followers (Shaw 1988: 200): "Tsung Ping applied a principle that he learned from Hui-yüan namely, that an image can convey the spiritual presence of a person or an object that is no longer physically present" (Shaw 1988: 201). Bush, on the contrary, is of the opinion that Zong's "appreciation of the vast expanse of the universe and the emptiness of unpeopled nature is distinctly Buddhist in cast” (Bush 1983: 133).

22 Wenfu, p. 25.

23 Wenxin diaolong, p. 295.

24 Cai 2004: 328-329.

25 Cai Zong-qi speaks about one’s “daemon's out-of-body flight” (Cai 2004: 329).

26 "In depicting the flight of imagination, [...] Lu [...] accentuate[s] its transcendence of normal restrictions of time and space. Lu writes, 'My essence galloping to the world's eight bounds, /My mind roaming ten-thousand yards, up and down [精篤八極，心游萬仞。Characters added]... He observes all past and present in a single moment, /Touches all the world in the blink of an eye. [觀古今於須臾，撫四海於一瞬。Characters added]”' (Cai 2004: 329).

27 Cai 2004: 328.

28 "“'Concentration of vital essence" and "entering the shen" respectively mark the inactive and dynamic states of the secondary human shen. These two states [...] are conspicuously similar to, if not identifiable with, the two major phases of literary creation: the initial quiet contemplation and the ensuing dynamic flight of imagination." (Cai 2004: 328). 
operandi of heaven and earth", an "everlasting process of change and transformation" [...] "usually called the Dao or yin-yang". ${ }^{29}$ For Cai, this "roaming of the heart” (you xin 遊心) hence means “nothing but a daemonic flight along with the process of transformation" 30 . And while this reveals an obvious continuity of this particular conception of artistic production to earlier traditions of preBuddhist Chinese thought, ${ }^{31}$ it also displays a striking resemblance to contemporary descriptions of Buddhist exercises of concentration: When Lu Ji describes the suspension, during the dynamic flight of imagination inspiring literary production, of the limits and dimensions of time and space, this is reminiscent, both in content and wording, to the alleged supernatural powers (abhijña $)$ of a Buddha, arhat or bodhisattva on the fourth level of meditation (dhyāna), a term often translated into Chinese as shentong 神通, lit. something like 'spiritual penetration'. In a more specific usage, this expression is also shorthand for shen $r u$ yi tong 神如意通 ('all-pervasion at one's will'), i.e. the fifth of these supernatural powers, namely the ability to be anywhere and to do anything at will ( r ddhi-sākșātkriy ā, 'manifestation of supernatural power', also shen zu tong 神足 通, lit. 'all-pervasion on spiritual feet'). ${ }^{32}$ Thus, according to the Mahāprajñāpāramitaśāstra (Dazhi du lun 大智度論), translated by Kumārajīva in 402 CE, the bodhisattva "supremely [playing] (you xi 遊戲) with the [superknowledges $(a b h i j \tilde{n} \bar{a})][. .$.$] goes at will and spontaneously to immense and infinite universes$

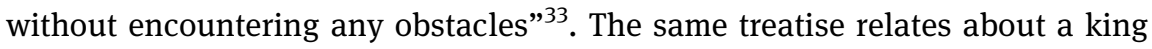
who, after the attainment of pratyekabuddhahood and "endowed with the six superknowledges [...], went flying to a solitary forest" ${ }^{\text {34 }}$. And while in a sutra

\section{Cai 2004: 328.}

30 Cai 2004: 328.

31 K.C. Chang has famously pointed out the similarity of such "daemonic flights" attested in medieval texts such as Ge Hong’s 葛洪 (284-364) Baopuzi 抱朴子 to shamanistic journeys allegedly harkening back as far as to the Neolithic period (Chang 1999: 50-52; see also Bush 1983: 134). On the link between Ge Hong's "alchemical” Daoism and landscape, especially mountains, see Shaw 1988: 187.

32 Soothill/Hodous 1937: 123.

33 “今得自在遊戲。能至無量無邊世界。菩薩住七地中時欲取涅槃。爾時有種種因緣。及十方 諸佛擁護。還生心欲度眾生。好莊嚴神通隨意自在。” T 1509, p. 418a20-24. See Lamotte s.a., vol. 5, p. 2018. The same association of samädhi, supernatural powers and the ability to fly through the innumerable Buddhalands is documented in the 佛說須真天子經 Suvikrāntacintādevaputrapariprcchā (tr. Dharmarakșa 竺法護 in 256 CE [Mai 1996: 52]) which states that "those who constantly tame their mind and quietly abide in concentration (samädhi) [...] [have] the characteristic of wisdom and fly, in their spiritual power, through the transformations and get to the hundreds of millions of Buddhalands (buddhakșetra).” (常調心寂三昧 ... 以是故智慧相 / 神通具 飛變化 / 便去到億刹土。T 588, p. 110a03-05).

34 “具六神通即飛到閑靜林間。” T 1509, p. 191b02-03. Lamotte s.a., vol. 2, p. 829. 
translated into Chinese by Dharmarakșa 箨法護 (229-306), the Buddha teaches Ānanda that all Buddhas "have a samādhi called the 'mastery of abhijña', (shen tong $z h u$ 神通主) which enables them to help those without these spiritual powers "fly through the empty space" at a height of seven trees ${ }^{35}$, the Dajijing 大集經, translated by Dharmakșema 曇無讖 (385-433), tells a story about five bodhisattvas (dasheng 大聖) who “with their supernatural powers (abhnijñās) flew up into the empty sky and onto the peak of the great mountain Kharādiya, the abode of Buddha Sākayamuni" 36 . Spiritual flights not only through infinite space, but also to remote areas like forests and mountains are thus as well established in Buddhist lore as they are anchored in pre-Buddhist Chinese traditions themselves. Still, it is instructive to see, in this particular context, that in a short treatise on the elucidation of Buddhahood (Mingfolun 明佛論) ${ }^{37}$, Zong Bing, the very author of the famous preface on painting mountains and waters, ${ }^{38}$ has his interlocutor ask the following: Why - in spite of the overall equivalence of Confucius' instructions about altruism with the compassion of a bodhisattva and the extreme closeness of Laozi's doctrine of disengagement with the Buddhist teaching of nirvāna - does he still not admit that in the case of these two teachers "their spirit is pervasive and that they have attained Buddhahood" (其神通成佛). ${ }^{39,40}$ This suggests that Zong Bing, for whom the "native” doctrines regardless of their admitted compatibility with Buddhism fail to exhaust the profundity of the latter, considered abhijñ $\bar{a}$, that is, the "spiritual pervasiveness" allegedly allowing one to embark on spiritual flights, a privilege of those who

35 佛說方等般泥洹經 Caturdārakasamādhisūtra (T 378, p. 928b05-06): “阿難。諸佛世尊有三昧 名神通主。住是三昧。令無神通者飛行虚空。神足能高七樹。” (Ānanda, all the Buddhas, the world honored ones have a samādhi (concentration) which is named the mastery of penetrating spirit (abhijña). Those who dwell in this samādhi, let those who have no penetrating spirit fly through empty space, and their spirit feet are able to reach a height of seven trees).

36 “以神通力飛騰虛空。到佉羅坻大山頂頭牟尼聖人處所。” Dafangdeng dajiijing 大方等大集經 (Mahāvaipulyamahāsamghātasūtra), T 397, p. 273c18-c20.

37 Cf. Bush 1983: 132. A partial translation of this treatise is available in Liebenthal 1952: 378-394. 38 Zong Bing is known to have spent some time at Mount Lu where Huiyuan, a founding figure of Chinese Pure Land Buddhism, had established a monastery (Bush 1983: 132; Shaw 1988: 199-200). According to Miranda Shaw, Buddhists at Huiyuan's monastery “considered [landscape] to be an integral part of their spirituality [...] and experienced dramatic moments of self-transcendence through unity with landscape” (p. 190).

39 Hóngmingji 弘明集 (Collection on the Elucidation [of Buddhism]), T 102, p. 12a8-9.

40 By which he would diverge from the common Buddhist stance according to which only the sixth abhijñ $\bar{a}$, the supernatural 'consciousness of the waning of vicious propensities' (漏盡通 āsravakșaya-jñāna) sets the Buddhist sages apart from magicians (Soothill/Hodous 1937: 123; 138). 
have attained Buddhahood. ${ }^{41}$ Whatever the Buddhist, Daoist or Confucian ${ }^{42}$ elements in Zong's thought, it seems as probable that his notion of "spirit" - after all the key concept in his theory of painting - is more deeply entrenched with Buddhist connotations than its linguistic surface may suggest. ${ }^{43}$ And while the autochthonous Chinese connection between meditational exercises and spiritual journeys resemble their Buddhist counterparts, the very similarities are on such a general level that it seems elusive to trace their various elements to a specific source. What is to be noted, in contrast, is that texts like Lu's rhapsody on literature or Zong's essay on painting differ in one essential respect from the reports on spiritual journeys just discussed: Their focus is not on the meditation and resulting magical powers of spiritual ascent, but on literary and artistic production. ${ }^{44}$ Moreover, as Tian Xiaofei observes, these texts emphasize the

41 Zong's own writings confirm that he associated "the ascent on high with the experience of cosmic space in a Buddhist sense” (Bush 1983: 136).

42 Bush's tentative characterization of Zong's landscape Buddhism in his treatise on painting as "Confucian" rests on her observation that the sages he mentions and with whom he, in an unmistakably Daoist manner, seeks communion in the mountains are related with the Confucian rather than Daoist tradition (Bush 1983: 134). What is notable, is that unlike the Preface, the apologetic Mingfolun prominently stages Daoist immortals.

43 In view of the guiding role of Buddha and the sages in Zong's texts, Susan Bush considers him “closer to a kind of 'Confucian Buddhism' than a 'Buddho-Taoism”' (Bush 1983: 133). As for Zong's preface on painting mountains and waters, she remarks that "it is conceivable that Buddhism, which is never explicitly mentioned, is the most important frame of reference in the essay" (Bush 1983: 134). For a discussion on Zong's notion of shen ('spirit') and its Buddhist underpinnings, see Bush 1983: 140-143.

44 On this see Obert 2000: 849: "Reading [Zong Bing's text] as a euphoric report on the fulfilment of a Buddhist quest for awakening and detachment "from nature" obviously misses its substance. In spite of its plausibility regarding Zong Bing's daily life as the background of the "Preface" (Lebenshintergrund), the lop-sided interpretation within the framework of a "landscape Buddhism" based on Lushan fails to do justice to its genuine intention to provide a theory of painting (malereitheoretische Bestrebungen). [...] large parts of the text do not address the contemplation of landscape as a "form of meditation". Rather they provide an argument for the transition to the contemplation of painted views of mountains and waters. And as a "Buddhist" hymn on nature need not necessarily imply a theory of aesthetics (ästhetische Theorie), which hence would rather seem imputed to it with hindsight, it is only on the basis of this observation that Zong Bing's "Preface" has first and foremost to be read as a writing on aesthetics, a text on art theory." (my translation). See also Ledderose (1983: 172). However, in contrast to Obert, Ledderose holds that "[a]esthetic values generally originate in a religious sphere", and that, "for a better understanding of many aesthetic phenomena it is therefore helpful to trace their religious roots" (p. 165). Ledderose invokes the notion of "secularisation" to capture the development of an increasing liberation of aesthetic from religious values which leads to an autonomous aesthetics. The crucial issue thus obviously amounts to the question whether it makes sense to speak about "aesthetics" at all at any time before the 18th century when this concept was first raised and developed by philosophers like Alexander Gottlieb Baumgarten (1714-1762). 
imaginary aspect of such roaming experiences. ${ }^{45}$ As we have indicated before, this is clearly a mode of viewing these spiritual journeys that was inspired by the advent of Buddhism. Eventually, our short glimpse at the intellectual context of the rise of Chinese reflections on landscape painting clearly indicates that Buddhist elements, notably the practice of samādhi so prominently figuring in the quote from Dong You above, constitute an essential factor of these considerations since the very beginning - just as explicit references to Daoist texts, notably the Zhuangzi, remain crucial also in later periods, as e.g. reflected in Dong's notion of 'heavenly impulses' (tian ji 天機) in the quote cited above. Still, what it shows most clearly is that the subliminal Buddhist subtext in these early texts on the arts is closely related to the notion of shen. This word prominently occurs both in neologisms for supernatural powers and knowledges resulting from samādhi, that is exercises in mental concentration eventually leading to Buddhahood, like shen tong 'spirit(ual) pervasion', and in the central concept in Zong Bing's theory on mountain and water painting. In Zong's view, the production and appreciation of this art culminates in the attainment of 'spiritual liberation' (chang shen 暢神), a phrase referring to a “spiritual flow”, or, in a more literal translation, a practice of "letting [one's?] spirit flow in an unobstructed way".

However, as seen in the excerpt from Dong You's portrait of Li Cheng at the beginning of this essay, the use of the notion of 'spirit' in early Chinese texts on painting is not restricted to landscapism. Along with the alleged concern of early authors for the adequate depiction of the real shapes before their eyes, Dong also criticizes $\mathrm{Gu}$ Kaizhi for his focus on painting the eyes in portraits. It is this care which $\mathrm{Gu}$ devotes to the organ of sight that is condensed in his famous formula of conveying the portrayed person's spirit and depicting the expression, literally: the 'radiance', of his face (chuan shen xie zhao 傳神瀉照) - more freely characterized as a person's “aura” above. Cai Zong-qi, who experiments with the Latin terms anima and animus for rendering shen's animating and inspiring (i.e., cognitive) functions respectively, remarks that "for $\mathrm{Gu}$ the anima or the innermost personality of the subject in portrait painting is revealed, first and foremost through the eye" ${ }^{46}$. He relates this observation to passages in the Mencius and other classical texts that suggest that the eyes reveal a person's moral character, and he invokes a debate, emerging in the Han period (206 BCE-220 CE), over the relation between shen and the eye. In this debate, partisans of the independence of shen are said to have opposed authors like Wang Chong 王充 (21-91 CE) who argued for its reliance

45 "[...] [I]n these Eastern Jin texts, the roaming is always carried out in the mind." (Tian 2004: 89).

46 Cai 2004: 317. 
on the anatomical basis of the eye of flesh and blood - a controversy which in a sense is reiterated during the medieval period in a notorious series of heated disputes on the 'perishability of shen' (shen mie 神滅). ${ }^{47}$ Cai insinuates that the intimate relationship between the organ of sight and 'spirit' is thus essential to understand the emphasis which $\mathrm{Gu}$ Kaizhi lays on the accurate depiction of the eye - which medical texts characterize as a genuine concentration of the 'essence' (jing 精) from all inner organs. ${ }^{48}$ Note that the centerpiece of Gu's reflections on painting, the eyeball (jing 睛), is not only fully homophonous with jing 精, but according to Chinese medicine it is nothing else than an agglomerate of this most refined kind of matter. Again, the notion of spirit is closely tied with seeing and sight, even though the perspective is inverted. The eye and the spirit, which allegedly abides in it, are here discussed as observed objects of sight to be captured in painting rather than agencies or media that allow the observing "subject" a specific visual or visionary experience. Elaborating on a terminological distinction established by Qian Zhongshu 錢鍾書 (1910-1998), Cai Zong-qi notes that this "primary human shen" as concentrated in one's eyes is "inseparably bound" with the 'human body' (xing 形), ${ }^{49}$ and he sets it apart from the medium of spiritual flights discussed before, which he dubs "secondary" free" ${ }^{51}$. As Cai convincingly shows, the medieval views about shen clearly harken back well into the Western Han and pre-imperial periods, that is, a time before the Buddhist "conquest" of China. And even if, as we have suggested above, the medieval discourses about 'spirit' and its role in the arts also seem to allude to specifically Buddhist notions and positions, he thus has the merit to have opened a promising perspective pointing beyond Buddhism.

47 Zong Bing himself partook in this debate, siding with those who claimed that spirit does not perish after the decay of the body (Bush 1983: 133; for a recent discussion of Zong's position as expressed in his Mingfolun (Treatise on Elucidating Buddhahood), see Park 2012: 212-214). This idea is closely related to Huiyuan's approximation of a universal 'spirit' with the Buddha's dharmakāya. The irony of this dispute, long noted by Sinologists, is that it was the Buddhists adherents of the teaching of non-self - who defended the imperishability of spirit, while some of their fiercest contenders like Fan Zhen 范縝 (c. 450-515 CE) were Confucians - who held the ancestral cult in high esteem, which seems inherently related to complex notions of individualized 'spirits' or 'souls'. Although sinological luminaries such as Paul Pelliot have well documented the debate on the perishability of shen, the conceptual implications of this pivotal term, commonly translated as 'soul', often remain unaddressed. For a recent exception see the discussion in Radich 2014: 473.

48 Cai refers to a passage in the Ling shu 靈樞 (Spiritual pivot) section of the Huangdi nejing 黃帝 內經 (Inner Classic of the Yellow Emperor) (Cai 2004: 318). See n. 67, pp. 15-16 below.

49 Cai 2004: 325.

50 Cai 2004: 325.

51 Cai 2004: 320. 
The main part of this paper will continue this search and attempt to identify Chinese texts about seeing and sight from the pre-Buddhist period. The three preliminary case studies at its core provide insights into the semantics and philosophical implications of some of the vocabulary which eventually transformed into key terms of the reflections on art production as discussed above. The first section will be dedicated to the term xiang 想. As we have seen, this word, at least in the guise of this particular character with the heart signifier, is only rarely used before the medieval period. Concomitant to a sudden rise in frequency in the Eastern Jin Dynasty, it adopts the new meaning of intentional 'imagination' or 'visualization'. A close reading of its use in Wang Chong's argumentation against the existence of ghosts in the Lunheng 論衡 (Balance of [Conflicting] Explanations) will reveal the anatomical and physical underpinnings of his views on merely imaginary or illusionary objects of sight (and of the other senses) as opposed to the vision of 'real' (shi 實) things. Wang Chong's "naturalist"52 account shows an intimate connection of the phenomenon of (unintended) imagination and illusion with his specific interpretation of essence (jing) and spirit (shen). A second section presents a short discussion of the process of seeing as illustrated in the Zhuangzi commentary attributed to Sima Biao 司馬彪 (d. 306 $\mathrm{CE}$ ), who lived at the eve of the Eastern Jin period. It documents a view on seeing which both sticks to a theory of "immission" - without an external source of light there is no sight - and the idea of an independent faculty of sight called ming 明 'perspicacity' (lit. 'clarity'), sometimes translated as 'intelligence', but rather meaning something like 'brightness', 'translucency' or 'transparency'. A third section is dedicated to a chapter of the Xinshu 新書 (New Documents), a work attributed to the Western Han Confucian Jia Yi 賈誼 (c. 201-169 BCE). It is thus the oldest, but also the most difficult, source discussed in this study. However, in spite of its conciseness, its peculiar terminology and lack of explicitness, it is still valuable in highlighting a crucial connection between light, seeing, shen (spirit), and ming (perspicacity). Even if many details will have to remain inconclusive, it will be shown that Jia considers 'spirit' and 'perspicacity' as genetically related to each other and how he integrates both of them in what one could call a cosmology of light which associates the notions of dao 道 (the 'Way') and de 德 ('virtue') with metaphors of luminosity. ${ }^{53}$ To use a phrase by Cai Zong-qi, Jia Yi's text thus

52 Alfred Forke (1867-1944) had early on compared Wang's emphasis on the "knowledge of the natural causes of things as an antidote against superstition" to the materialism of Epicurus and Lucretius (Forke 1907: 13).

53 In a way this at least helps putting into perspective the established view of an alleged priority of the sense of audition over sight in ancient China (see Nylan 2008: 129, and, recently, Gong 2017). 
suggests a specific sense in which the eye in ancient China was indeed conceived as the "home or even the source" 54 of the spirit.

II

The following discussion starts from the explanation, by the Eastern Han scholar Wang Chong (31-91 CE), why people see ghosts although ghosts - in his view - do not exist. This not only shows us how he conceives of the process of seeing, but it also sheds some light on the development of the Chinese vocabulary of imagination and recollection which became so prominent in discourses about vision and visuality from the Eastern Jin (316-420 CE) period onward.

Wang Chong argues against the common view that ghosts are the spirits of dead people. He does so by "psychologizing" the vision of ghosts: It is due to our attachment to memories and our fixation on the images we recall that the vision of ghosts is provoked:

Wherever, between heaven and earth, there are ghosts, it is not that the finest essence and spirit of people dying would produce them. All of them are brought about by people indulging in (lit. 'longing for') memories and storing [previous] impressions. For what reason (lit. 'whence') do they bring them about? If people are sick they are worried and anxious, and when they are worried and anxious they see ghosts come out. ${ }^{55}$

凡天地之間有鬼, 非人死精神為之也, 皆人思念 ${ }^{56}$ 存想之所致也。致之何由? 由於疾病。 人病則憂懼, 憂懼見鬼出。57

It is their worries and anxiety which lead people to "fixate" on the recollection of their impressions. This results in their seeing things which are not there, literally seeing things “in the void” ( $x$ u jian 虛見). While it is difficult to precisely determine the semantics of the expression "cun xiang" - translated as "storing impressions" above - it seems plausible to assume that the former "cun", resumed by the gloss

54 Cai Zong-qi closes his discussion on the discourse about the relationship of body and shen with the remark that the anatomical faction "would have undermined their opponents' stance far more effectively if they had gone one step further to claim that the eye was the home or even the source of shen" (Cai 2004: 317).

55 Cf. Forke 1907: 239.

56 Shiming 釋名, 'Shi yanyu' 釋言語 (4.1/45/3; references are given according to the ICS Ancient Chinese Texts Concordance Series. Format: chapter/page/line): “念, 黏也。意相親愛, 心黏著不 能忘也。” “'To memorize' is 'to stick to'. One thinks and imagines one's relatives and beloved ones, and the heart/mind sticks and attaches to them without being able to forget them.”).

57 Lunheng 論衡, ‘Dinggui’ 訂鬼 1 (65/288/27-28). 
"fixate" above, is here a causative transitive verb, ${ }^{58}$ while the second is its nominal object, meaning something like the internalized visual traces of events experienced in the past. That Wang explicitly relates it to the "technical" meaning of xiang 相 as 'to judge', 'to inspect', commonly written without the semantic classifier 心, suggests a possible etymology of the term: The illusions of the sick are paralleled to the "characteristics" or "images" an expert who judges on the quality of things has in mind when he scrutinizes the objects he sets out to assess. ${ }^{59} \mathrm{We}$ will resume this point further down. In our present context, another point of relevance is the fact that the expression "cun xiang" which Wang clearly refers to a spontaneous and obviously unintentional imagination of non-existing, empty things is the same term, which in religious or meditative contexts assumes, some centuries later, the technical meaning of intentional "visualization" in meditation. ${ }^{60}$ Given the overall absence of the character 想 xiang in Wang Chong's work ${ }^{61}$ and in view of the fact that Wang invokes the transitive verb xiang 相 to illustrate his use of 想, one may even speculate that it was the accidental coincidence of Wang's expression with this later semi-technical term which led subsequent editors of the text to add the semantic determiners exclusively in this particular case and nowhere else in his voluminous work.

Whenever a human is not sick, he is neither worried nor anxious. Hence, when he becomes ill and sleeps on his mat, he is in fear and anxiety, and ghosts arrive. When he is in fear and

58 In later Daoist meditation the verb cun "is used in its causative mode, in the sense of 'to cause to exist’ or 'to make present”' (Kohn 2008: 287). According to Pulleyblank (1991: 32) cún (^dzwว̀n)

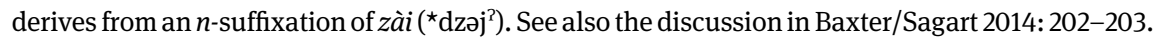
59 This observation is reflected in Axel Schuessler's analysis of xiàng 相 'look at/inspect' as an extrovert (exoactive) verb belonging to the same root as endoactive xiăng 想 'to think/to imagine' (Schuessler 2007: 531).

60 In later religious Daoism cun and xiang refer to the production of a vision of one's spirit and an image of one's body respectively. See Kohn 2008: 287-288, who presents a definition by Sima Chengzhen 司馬承禎 (647-735).

61 The character occurs less than a dozen times in pre-imperial texts. The 'Jie Lao' chapter of the Han Feizi 韓非子 has two occurrences (20/39/19), Lüshi Chunqiu 呂氏春秋 has two (2.3/9/11; 17.5/ 104/13); the Guanzi 管子 has one instance in the 'Nei ye' 內業 ('Inner Exercises') chapter (16.1/116/ 15). Here the term is related to the exchange of a person's 'essence' and 'spirit' (jing shen 精神) in their communication with the outside world (See pp. 50-56 below). A more archaic usage is attested in the Zhouli 周禮 (Rites of the Zhou), which uses the character to identify one of the ten 'patterns of light' ( hui fa 輝法) the 'inspector of ominous vapors' (shi jin 視䃽) is charged to observe. The character here writes a word for luminous phenomena which Zheng Zhong 鄭眾 (Sinong 司農, d. $83 \mathrm{CE}$ ) in his commentary identifies as visual effects of the mixing up of vapors that exhibit similarities which allow the expert to shape his imaginations on them (xing xiang 形想) (Cf. Zhouli, p. 382). 
anxiety, he indulges in (fixates on) images [of former impressions], and when he indulges in images, the eye sees [things] in the void. ${ }^{62}$

\section{凡人不病則不畏懼。故得病寝衤, 畏懼鬼至。畏懼則存想, 存想則目虛見。63}

For Wang, the vivacity of the hallucinations reflects the degree of psychical derangement and physical pain: the stronger the disease, the more concrete and the livelier is the imagined ghost. Light fear causes the vision of ghosts; fearing death, one sees them in anger, and when there is pain, ghosts appear beating and fettering the sick. All of this comes up within one's imagination, literally via "indulgence in images", and "there need not necessarily be something real to it" (wei bi you qi shi ye 未必有其實也). The illusionary “empty’ ( $x u$ 虛) nature of imagination is thus opposed to the tangible and solid, literally 'filled' (shi 實), character of real bodies. $^{64}$

However, Wang Chong does not stop at this "psychological” explanation of the hallucinations of a sick person. Notice that he links these with an "anatomical" account on the causes of misled imagination:

This finest essence memorizes saved images (lit. 'sticks to the indulgence in images'). Some of it spills into the eye, some spills into the mouth, some spills into the ear. When it slips into the eye, the eye sees its (the image's) shape, when it slips into the ear, the ear hears its voice; when it slips into the mouth, the mouth speaks about the corresponding matter. ${ }^{65}$

夫精念存想, 或泄於目, 或泄於口, 或泄於耳。泄於目, 目見其形; 泄於耳，耳聞其聲; 泄於口，口言其事。6

As Wang presents the matter, there is a physical cause of the imaginations of the sick: The crucial role is played by jing 精 in this context, so-called essence, the most rarefied kind of matter gathering in our body. As we know from other sources, ${ }^{67}$ it is

62 Cf. Forke 1907: 239.

63 Lunheng, 'Dinggui' 2 (65/289/1).

64 Lunheng, 'Dinggui’ 2 (65/289/4-7). Cf. Forke 1907: 239.

65 Cf. Forke 1907: 239-240.

66 Lunheng, 'Dinggui' 2 (65/289/7-8).

67 This is most explicit in a chapter of the Ling shu jing 靈樞經 (Classic of the Numinous Pivot) entitled 'On major delusions' (Da huo lun 大惑論), which reads: “The eye is the essence of the five viscera and the six bowels, it is the place which the protector(s), and the guardian(s), the hun [spirit], and the po [spirit] constantly encamp, the place where (animating) spirit breath arises. Hence, when the spirit is exhausted, then hun and po dissipate, intention and thinking unsettle. Hence the pupil and the black [parts of the] eyeball are modeled on yin, and the white part of the eyeball and the red veins are modeled on yang. Hence, as yin and yang are conveyed in harmony, the essence clarifies.” 目者, 五藏六府之精也, 營衛魂魄之所常營也, 神氣之所生 也。故神勞則魂魄散, 志意亂。是故瞳子黑眼法於陰, 白眼赤脈法於陽也。故陰陽合傳而精 
thought to concentrate in the heart and in the eyes, and it is associated with consciousness. Even though neither the semantics nor the syntax of the expression “jing nian cun xiang” (精念存想) is entirely clear, it seems uncontroversial that it is this sublimated matter which "sticks" or "attaches" to the "images" collected in a person's memory. ${ }^{68}$ Regardless whether the second term "cun" is to be interpreted actively as 'to collect/to keep' etc. - which would be the syntactic default - or passively, in the sense of the "images" '(re-)collected' or 'kept in mind', it is clear that Wang provides a physical explanation of consciousness. It is only when this fine stuff, which is somehow storing the images of objects (most probably as encountered in previous experiences), is stirred up that parts of it spill over and flow into the sensual organs, to the effect that one sees, hears or speaks about things which are not present in reality. While the ghosts one sees thus lack any real referent out there, their appearance still has a "physical" cause, namely the fact that the essence of the sick is instigated internally by fear and pain and thus provokes the sensual organs to hallucinate things which are not there. Whether one sees ghosts by daylight or one hears them in dreams, both cases rely on the spirit of the essence. Hence, "fear and anxiety on the one hand and indulgence in images on the other are one and the same reality" ${ }^{\prime \prime}$ : Again, the inner structure of the phrase "jing shen" is unclear. What speaks against simply translating the entire expression just as "spirit" is the fact that Wang appears to draw a clear difference between 'essence' on the one hand and 'spirit' on the other. We can ignore this problem at this point and resume it further down. What is important here is the

明也。(cf. Unschuld 2016: 755-756; or Unschuld 2015: 868, in German). Cai has a rather free translation: "The eyes are the essence of the five parts and six organs of the viscera. They are where the ying (breath) and the wei (breath), the hun (soul) and the po (soul) constantly dwell and where the spirit and breath (shenqi) are born. So if the shen is exhausted, the hun and po souls will dissipate and the zhiyi (intent and will) will be unsettled. Therefore, the pupils or the black part of the eye are modeled on the yin. The white part and red blood vessels are modeled on the yang. Yin and yang combine as one, and so there is the luminous vital essence.” (Cai 2004: 318). A vastly different translation based on a fundamentally different - not all too convincing - parsing is presented by Wu Jing-nuan. See Ling Shu, p. 279. Cf. also Huang Di Nei Jing Ling Shu, p. 868.

68 Early collocations of nian and xiang also appear in the description of ritual ancestor worship. Sima Biao (d. $306 \mathrm{CE}$ ) explicitly relates the phrase nian xiang to the spontaneous memory of one's deceased relatives - Kenneth Brashier renders this expression as "contemplation and reflection" (Brashier 2011: 3). What relates this example to Wang Chong's vision of ghosts is their involuntary nature, what connects it with later uses in meditational settings is its religious dimension. In spite of our spontaneous memories of the dead, Brashier comments on this passage, "the essence of sacrifice ... had to be nurtured in our minds" (ibid.).

69 "What we see, while awake, or hear, while asleep, is all the work of our spirit, of fears and thoughts, which amounts to the same.” (Forke 1907: 240); (覺見臥聞, 俱用精神; 畏懼、存想, 同一實也。[65/289/9-10]). 
observation that Wang Chong explains away the imagination of ghosts as a mere effect of physical processes. There is only one reality: Judging from the verb used to describe its movement, xie 瀉, 'to leak' or 'to disperse', the bearer of consciousness, that is shen - the sublimation of matter gathering inside one's body and concentrating in the heart - is conceived in analogy to a liquid which can easily get stirred up and caused to spill over. The single "reality" underlying psychological processes thus appears to be precisely this physical fluctuation of liquids ${ }^{70}-$ and the sensual hallucinations experienced by the sick are mere "imaginations". It is thus clear that, at least in this case, mental phenomena are explained in physical terms. The psychological phenomena described are not accorded any independent reality.

As we have already seen, Wang Chong adopts his term for imagination from the context of professional inspection: He illustrates this with the mythical figures of Bo Le 伯樂 and Pao Ding 庖丁, two experts in their respective fields, who knew everything on assessing the quality of a horse and on dismembering a sacrificial ox. ${ }^{71}$ But their constant occupation with their profession also determined their way of looking at things: Habitually scrutinizing horses or cutting apart oxen, they have internalized the respective schemes and procedures, eventually ending up in a kind of déformation professionelle, which views everything as a horse or a sacrificial ox. Obviously, this cannot mean that, in a literal sense, they only saw horses or dead oxen. What Wang tries to convey is that they always had the patterns and characteristics of a good horse or the anatomy of an ox in their mind, regardless of the nature of the real things they were actually seeing in a given moment. If we take this comparison by Wang Chong serious, we thus can infer that xiang, the mental images of a horse or an ox in the mind of these experts, and, per analogy, the ghosts imagined by a sick person, are not genuine depictions, but rather reductive "outlines" or "contours" of the real shapes of these things. This seems to be confirmed by the following passage from the Huainanzi 淮南子 about 'assessing' (xiang 相) horses:

The directions and tendencies of the words of the hundred specialists (for politics) are mutually contradicting, but insofar as they agree with the Way they are [part] of one and the same body (whole). They can be compared to the meeting of the silk [strings], the bamboo [flutes], the bronze [bells], and the stone [drums] whose [piece] of music is one and the same; even if the [respective] particular specialists are different, they do not fall short of the [entire]

70 Rudolf Pfister nicely puts this as follows: “According to the ancient Chinese physiological knowledge 'essence' - jīng 精, a mucilaginous body sap, nourishes not only the whole body, but is also especially important for the eyes and the visual function.” (Pfister 2012: 44).

71 Lunheng, 'Ding gui' 2 (65/289/2-4). Cf. Forke 1907: 239. 
body (whole): What Bo Le, Han Feng, Qin Ya, and Guan Qing discern is in each case different, but they are one and the same in their assessing (lit. knowing) horses. ${ }^{72}$

故百家之言，指奏相反，其合道一體也。譬若絲、竹、金、石之會樂同也，其曲家異而不 失於體；伯樂、韓風、秦牙、管青，所相各異，其知馬一也。 ${ }^{73}$

Apparently, the four specialists for validating the quality of horses base their assessment on different criteria, as the following passage from the Lüshi Chunqiu 呂氏春秋 (The Spring and Autumn of Mister Lü) states in even more explicit terms:

Take those in antiquity who were good at assessing horses: Han Feng judged the mouth and teeth, Ma Chao judged the cheeks, Zinü Li judged the eyes, Wei Ji judged the whiskers, Xu Bi judged the backbone, Toufa He judged the chest, Guan Qing judged the lips, Chen Bei judged the gaskins and cannon bones, Qin Ya judged the front, Zan Jun judged the back. All these ten people were among the best experts in the world, but that by which they judged [the horses] was not the same, they saw only one characteristic of a horse, but they knew whether its rank was high or low, its feet were unsteady or light, its constitution was robust or fragile, its abilities good or bad. This is so not only with judging horses. Humans also have their characteristics, just as well as affairs and countries. ${ }^{74}$

古之善相馬者：寒風是相口齒，麻朝相煩，子女庽相目，衛忌相髭，許鄙相泦，投伐褐相 胸脅, 管青相唇肳, 陳悲相股腳, 秦牙相前, 贊君相後。凡此十人者, 皆天下之良工也, 其所以相者不同, 見馬之一徵也, 而知節之高卑, 足之滑易, 材之堅脆, 能之長短。非獨 相馬然也, 人亦有徵, 事與國皆有徵。75

It is thus clear that it is certain 'characteristics', 'marks' or 'traits' which are inspected by someone professionally engaging in xiang. This substantiates our suggestion that 'inspecting' things does not imply seeing the entire thing in its natural complexity. Quite to the contrary: It seems essential to its meaning that it refers to viewing only particular traits which are at the same time specific marks of a certain kind of thing. Xiang maybe typical or distinctive for a certain kind, but they are both reductionist and partial. And this, by the way, may have been the decisive factor why in Buddhist contexts this term was chosen as a translation for Sanskrit lakșana in the sense of the distinctive marks that allow one to recognize the Buddha.

72 "Thus, the designations and prescriptions of the words of the Hundred Traditions are mutually opposed, but they cleave to the Way as a single body. Compare it [i.e., the Way] to silk, bamboo, metal, and stone. In concert, they all [make] music. The sound and tradition of each is different, but none is lost from the structure. The assessment methods of Bo Le, Han Feng, Qin Ya, and Guan Qing were all different, but their understanding of horses was one.” Major et al. 2010: 415-416.

73 Huainanzi 淮南子, 'Qisuxun’ 齊俗訓 18 (11/99/27-28).

74 Cf. Knoblock/Riegel 2000: 543.

75 Lüshi Chunqiu 呂氏春秋, ‘Shijunlan’恃君覽, ‘Guan biao’ 觀表 4 (20.8/138/5-9). 
Returning to Wang Chong, we notice that his "rational" explanation of the vision of ghosts is not tantamount to a wholesale refutation of magic: Somewhat surprisingly, he seems to give credit to an account on emperor $\mathrm{Wu}$ 武 (157-87 BCE) of the Former Han who missed his dead spouse and had Daoists apply magical methods to '(re-)make' (zuo 作) her body. Wang does not doubt the reliability of the story, but only invokes the hazy and ephemeral nature of the consort's "replica" to argue that such 'artificial products' (wei 偽) are short-lived and lack the durability of 'spontaneous' or 'self-established' (ziran 自然) and 'genuine' (zhen 真) things. ${ }^{76}$ Wang's "physicalism" or "naturalism" thus does not imply a general dismissal of wizardry. What the ghosts as seen by the sick, the marks or patterns as viewed by the experts, and the visions evoked by the magicians have in common is their vagueness, their schematic and somewhat elusive appearance: they all lack the vivacity and tangibility of concrete real objects.

This specificity brings them close to another common word usually associated with imagination in the Lunheng: xiang 象, 'image' or 'symbol'. The famous pun in the 'Jie Lao' 解老 (Explaining the Laozi) chapter of the Han Feizi 韓非子 about people seeing the remains of an elephant (xiang 象) and imagining its living appearance on the model provided by the bones in front of them thus nicely illustrates that xiang were not conceived as detailed depictions but rather as rudimentary outlines of real things, merely "skeletal" images, so to say. ${ }^{77}$ A xiang stands for a mere trace, a substantially reduced image abstracted from (or anticipatory of) a concrete object. One sees the tusks of a dead elephant and imagines the living being; one sees an astronomical constellation and understands it as an omen of an upcoming event. An 'image' or 'symbol' in this sense thus relies on interpretation. It is not a mere representation. Even if the reasons may be different than in the case of the 'characteristics' discussed above, the effect is similar: in comparison to the thing it points at (zhi 指), a xiang 象 'image' is schematic and underspecified. In a sense, it is merely a 'schema' of the thing to which it points, be it a mere shadow of a past thing or an adumbration of an imminent object. ${ }^{78}$ When

76 Lunheng 論衡, ‘Ziran’ 自然, 6: 武帝幸王夫人, 王夫人死, 思見其形。道士以方術作夫人形, 形成, 出入宮門。武帝大驚, 立而迎之, 忽不復見。蓋非自然之真, 方士巧妄之偽, 故一見恍 忽, 消散滅亡。有為之化, 其不可久行, 猶王夫人形不可久見也。[54/241/13-16]).

77 Han Feizi 20/39/19-21.

78 For an illuminating discussion of the problems of translating xiang into philosophical terms like 'representation' see Obert 2000. A symptomatic illustration of the difficulties involved is Ledderose's remark on garden architecture that "the use of the term hsiang implies clearly that [it] [...] was meant to represent something" (emphasis in the original). Without further qualifications, there is an obvious danger that the concept of representation is implicitly identified with a theory of mimesis. But that a garden or any work of art is designed as a miniature replica of the cosmos or a remote place of salvation like sukhavati or Penglai does not imply that the emphasis in imitating or 
Wang Chong speaks about seeing people and things in dreams, he mentions the view of 'images' or 'silhouettes' of people and things (ren wu zhi xiang 人物之象). As none of the people one encounters in a dream will remember this meeting, one has to infer that it is only their 'images' or 'similes' one sees when asleep. ${ }^{79}$ In the 'Luan long' 亂龍 (Confusions about dragons) chapter, Wang moreover determines the communication through 'images' or 'symbols' (xiang 象) as the specificity of the human 'spirit' and 'soul' (shen ling 神靈), on which see further down. The discussion of such symbols as portents is another example where Wang Chong's "physicalist" explanation of psychological phenomena does not lead him to refute magical thinking: Rather, the alleged 'relatedness in kind' (lei 類) of 'spirit' and 'soul' with clouds and rain is invoked as an implicit cause for the formers' suitability as media of prognostication - just like clouds who indicate an imminent change of weather. ${ }^{80}$ As Wang puts it, 'spirit' and 'soul' show through 'images' or 'symbols' what is real (shi 實). ${ }^{81}$ As much as Wang Chong seems to be a physicalist,

depicting these presently unreachable confines is on the problem of representation. Just as well these artifacts could be conceived as schematic prefigurations intended to presage or even actualize, e.g. by means of 'sympathetic resonance' (ganlei 感類), the reality of these worlds and thus to testify or confirm the certainty of their future manifestation.

79 Lunheng, 'Jiyao' 記妖 13: “Some one might object that we also have direct dreams, insomuch as we dream of so-and-so, and on the next day see him, or, as we dream of a gentleman, whom we see on the following day. I admit that we can have direct dreams, but these direct dreams are semblances, and only these semblances are direct, which will become evident from the following fact: Having a direct dream, we dream of so-and-so, or of any gentleman, and, on the following day, see Mr. So-and-so, or the gentleman in question. That is direct. But, when we ask so-and-so or that gentleman, they will reply that they have not appeared to us in our dreams. Since they did not appear, the persons we saw in our dreams were merely their likenesses. Since so-and-so and the said gentleman were likenesses, we know that God, as perceived by Chien Tse, was solely a semblance of God.” (Forke 1907: 228); (人亦有直夢。見甲，明日則見甲矣；夢見君，明日則見君 矣。」曰: 然。人有直夢, 直夢皆象也, 其象直耳。何以明之? 直夢者, 夢見甲, 夢見君, 明 日見甲與君, 此直也。如問甲與君, 甲與君則不見也。甲與君不見, 所夢見甲與君者, 象類之 也。乃甲與君象類之, 則知簡子所見帝者, 象類帝也。[64/284/18-21]).

80 Lunheng, 'Luan long' 11: "VIII. Spirits speak to men by images, and not by realities. While asleep, they perceive these images in their dreams. When things are going to be lucky, lucky images arrive, and, when they are going to be unlucky, inauspicious signs appear. The fluid of spirits is of the same class as that of clouds and rain.” (Forke 1962 [1911]): 352); (神靈示人以象，不 以實, 故寝臥夢悟見事之象。將吉, 吉象來; 將凶, 凶象至。神靈之氣、雲雨之類。八也。 [47/215/15-16]).

81 Interestingly, this is then analogized to the use of earth dragons as magical artifacts to bring along rain. Wang thus equals 'symbol/image' (xiang) to 'artifice/artifact' (wei) and 'reality' (shi) to 'genuineness' (zhen): Lunheng, 'Luan Long', 12: “神靈以象見實, 土龍何獨不能以偽致真也? ” (47/215/18) ("Spirits show the truth by images; wherefore can clay dragons not attract the real by what is unreal?” Forke 1962 [1911]: 352). 
he also seems to be an epistemological sensualist: For him, what is "real", what a 'situation' (qing 情) is like, has to be ascertained through one's ears and eyes there is no other way to know it, even for worthies and sages. ${ }^{82}$

Before leaving Wang Chong and his analysis of sight, I would like to return to what he writes about human dreams, as this has far-reaching implications for how he conceives of seeing: His detailed explanation of dreaming in the 'Ding gui' 訂鬼 (Determining the notion of ghosts) ${ }^{83}$ chapter reads as follows:

When humans see ghosts this is because of a combination of the light of the eye (sight) and confusion in one's sleep. During daytime, a human's (animating) breath gets tired and his essence gets exhausted. When night arrives, he wishes to sleep, and asleep his light of the eye (sight) is inverted (turned inside), and when it has turned inside, the spirit of the essence sees the images of humans and things. When a human being is sick, his breath also gets tired and his essence exhausted, and even if his eye is not asleep, its light is already confused by his sleepiness. For this reason, he also sees the images of humans and things. Regardless whether the seeing of the sick is the same as the seeing of those who sleep, it resembles dreaming. When someone sees something, this person himself is able to know (the difference between) being awake and dreaming. When therefore he sees a thing without being able to know whether it is a ghost or a human being, this resembles the exhaustion of his essence and the tiredness of his breath. How can we ascertain this? By the fact that madmen see ghosts. The mad and crazy speak to themselves and do not manage to meet with sane (lit. 'good') people; and if their illness is severe, their essence is confused. Hence, if the sick are close to the time of dying, they are on a par with the mad. Sleep, illness and madness, all three are a loss and exhaustion of essence. Their light of the eye (sight) shines in an inverted way (turned inside) and therefore they all only see 'images' of humans and things. ${ }^{84}$

人之見鬼, 目光與臥亂也。人之書也, 氣倦精盡, 夜則欲臥, 臥而目光反, 反而精神見人 物之象矣。人病亦氣倦精盡, 目雖不臥, 光已亂於臥也, 故亦見人物象。病者之見也, 若 臥若否, 與夢相似。當其見也, 其人能自知覺與夢, 故其見物不能知其鬼與人, 精盡氣倦 之效也。何以驗之? 以狂者見鬼也。狂癡獨語, 不與善人相得者, 病困精亂也。夫病且死 之時, 亦與狂等。臥、病及狂, 三者皆精衰倦, 目光反照, 故皆獨見人物之象焉。

82 Lunheng, 'Shi zhi' 實知, 10: 實者、聖賢不能知性, 須任耳目以定情實。(78/333/14). Forke translates: "As a matter of fact, neither Worthies nor Sages are apt to know the nature of things, and want their ears and eyes, in order to ascertain their real character." (Forke 1962 [1911]: 126). Marc Kalinowski in his French translation argues convincingly that the phrase “知性”, which occurs nowhere else in Wang's text, should be emended to “性知”, which also would make better sense, as it would refer to a kind of knowledge one possesses by birth rather than by experience. Consequently he translates: "En réalité, sages ou saints, les hommes ne possèdent pas la science infuse. Ils doivent en passer par les organes de sens pour saisir le cours des événements [...]” (Kalinowski 2011: 213; see also Lunheng 78/333/14).

83 Lunheng, 'Ding gui' 3 (65/289/12-17).

84 Forke 1907: 240. 
Wang claims that what people suffering from a shortage of breath or essence see are not real things. Instead, their view turns inside and as a consequence what they view are merely "images" or "similes" of real things. He does not explicitly state that these images are saved in people's minds. But we may assume that this is indeed what the passage conveys. And if this is the case, xiang 象 here would be largely equivalent to the term xiang 想 as encountered in the expression “cun xiang" discussed above. Seeing an image is seeing a substantially reduced outline of a thing rather than the thing itself. Still, there might be a significant difference: as we have seen, Wang in spite of his "physicalism" does not refute oneiromancy altogether. What possibly distinguishes the images provoked by fear and anxiety from those appearing in dreams, is therefore that the former are the result of a person's distraction and hence only indicative of deficiencies of his individual constitution, while the latter are considered the effect of external influences and thus valid signs of imminent developments. The 'spirit' here is not stirred up by physical disruptions of the body but through the latter's sympathetic activation by something external. In spite of their commonality, their schematic or reduced character, both kinds of images, at least in the contexts discussed here, are thus distinct with respect to the nature of their causes and, accordingly, their relation to the "real" or "physical" world.

What Wang eventually says about eyesight implies the - empirically well established - fact that the eye is able to see even in the absence of an external source of light. The "inner light" which allegedly allows the eye to see things in dreams is located in the eye itself. This description, if it is more than just figurative speech, raises the intriguing question what kind of light it is that the eye possesses. We shall return to this below.

\section{III}

The latest passage about light and illumination I would like to discuss comes from the Zhuangzi-commentary by Sima Biao 司馬彪 (d. $306 \mathrm{CE}$ ). When he tries to make sense of the phrase “The eye does not see" (mu bu jian目不見), one of the sayings, sometimes called "paradoxes" which are attributed in the 'Tianxia' 天下 chapter of the Zhuangzi to the so-called “debaters" (bianzhe 辯者), he comes up with a depiction of the act of seeing which tells us something about his understanding of the processes involved. That he invokes the example of spotting a fish in murky water to illustrate his point may refer to a saying transmitted in the Huainanzi which compares the failure to grasp the relationship between dao and 
de with the futile observation (guan 觀) of small fish - presumably in a muddy pond. ${ }^{85}$

\begin{abstract}
When one views a fish in the water, one needs to see into the light of the water. Before one views a [contoured] thing, one first has to see the brightness of a light fish [i.e. a fish as present in light]. The scales are not the same as [their] resplendence, the scales are different from the resplendent scales [i.e. scales as present in resplendence], so that one sees the brightness [of the fish]. The shining bodies (shapes) of light are different from what does not shine, so that in viewing (things) we see only (from among) shining shapes (bodies), we do not see the shapes (bodies) [themselves]. The eye does not see at night, it does not depict (things) in the dark. Seeing (itself) is not the same as clarity (eyesight), it has something supporting it. That by which we see is clarity (eyesight). It's not the case that the eye only becomes clear (able to see) after being supported by light, [as like this] it would have nothing to see the light (Lit. The eye does not become clear only after being supported by light ...). Therefore [I say]: When it comes to the relationship between an eye and a thing, it has never occurred that there would have been one (= an eye) which sees [things].
\end{abstract}

水中視魚, 必先見水光中。視物, 必先見光魚之濡。鱗非曝。鱗異於曝鱗, 則視濡也。光之 曤形異於不曤, 則視見於曤形。非見形也。目不夜見, 非暗畫。見非明, 有假也。所以見者, 明也。目不假光而後明, 無以見光, 故目之於物未嘗有見也。 ${ }^{86}$

In this passage, Sima Biao first seems to present a physical interpretation of this sophism attributed to the debaters: He interprets their claim to say that the eye does not see things and argues that rather than things one sees the light reflected (or emitted) by things. The eye sees the sparkling light of the water, notices a shiny shadow appearing which turns out to be the resplendence of fish scales. But there is a difference between the fish and the scales on the one hand, and the light that appears in the form of a fish and the shining reflection of the scales on the other. More generally, what is visible is not the things themselves, but the light which they transmit to the eye. To see reflected light is not tantamount to seeing the things themselves. What Sima addresses next, however, appears to be a qualification of this observation: Although the eye does not see in the dark or at night, that is although it relies on the light as reflected by things in order to see, seeing as such is not exclusively due to the light. Light is presented as that on which seeing depends, as its condition, as it were. The cause why we see is "brightness" (ming 明) - which seems to be an equivalent of eyesight here. And eyesight, Sima

85 Huainanzi, ‘Lanmingxun’ 覽冥訓, 5 (6/51/14-16): “[...] how the Way compares with Potency / is like how leather compares with rawhide. / From a distance they [seem] close; / close together they [seem] far apart. / [One who] does not get the Way is like [someone] watching minnows. / Therefore, / The sage is like a mirror, / neither holding onto welcoming [anything], /responding but not storing up.” Major et al. 2010: 219-220.

86 Jingdian shiwen, vol. 3, p. 1588. 
Biao emphasizes, does not depend on the presence of light: Rather, it is eyesight which first and foremost enables us to see the light. But as the exclusive object of eyesight is light, no eye - the abode of eyesight - ever sees a thing. This short comment on chapter 33 of the Zhuangzi is typical for the casual and aphoristic way in which Sima Biao seems to have written his explanations of the various "paradoxes" transmitted in the Daoist classic. Given our focus on early theories of seeing, this note is nonetheless instructive: Even if the entry of Buddhism in China had begun more than a century before Sima Biao's death, the penetration of much of the intellectual sphere by the new doctrine had certainly not yet reached the intensity of the following two centuries. Assuming the correctness of Lu Deming's 陸德明 (ca. 550-630) attribution of this short passage to Sima Biao, who lived in the second half of the 3 rd and in the first years of the 4th century CE, i.e. in a period immediately before the time when specifically Buddhist ideas made their way into Chinese literati circles, there is a certain degree of probability that the analysis of seeing presented here is not yet affected by views transmitted from India. In spite of its shortness, it is clear that Sima propagates an "immission theory" of light: Light is that which reaches the eye from the outside. It is transported either directly or indirectly, as the radiance or reflection of objects. And it is only through the light they reflect or emit - this distinction is not made explicitly by Sima - that we see the objects. Moreover, the passage makes perfectly clear that Sima Biao is aware of the difference between light as the object of seeing and the eyesight, that is the faculty of seeing which only enables the eye (and hence a human being) to see the light. This faculty is called ming, literally 'clarity' or 'brightness'. We will return to this term in the fourth part of this paper.

A view contrary to Sima Biao is attested in the 'Zanxue' 讚學 (In Praise of Learning) chapter of the Qianfulun 潛夫論 (Comments of a Recluse) by the Eastern Han scholar Wang Fu 王符 (c. 82-167). Wang compares the light that enables us to see with the Way that enables us to grasp the invisible things, such as the 'Way of Heaven and Earth' (tian di zhi dao 天地之道) and the 'activities of spirits and apparitions' (shen ming zhi wei 神明之為):

夫是故道之於心也, 猶火之於人目也。中突深室, 幽黑無見, 及設盛燭, 則百物彰矣。此 則火之燿也, 非目之光也, 而目假之, 則為明矣。 ${ }^{87}$

Now for this reason, the relation of the Way to the heart is like the relation of fire to the eye of a human. When one enters a pit hole or a deep room, it is dark and black, and there is nothing he sees, but when he goes on to put on an illuminating (lit. 'intense') candle, then the many

87 Qianfulun 潛夫論, ‘Zanxue’ 讚學, 7 (1/2/12-13). 
things [therein] appear. This is due to the luster of the fire, not due to the light of the eye, but the eye relies on it (scil. the light) to become clear (i.e. seeing). ${ }^{88}$

Unlike Sima Biao, Wang Fu seems to suggest that the eye owes its brightness, that is: its ability to see things, to the light emitted by the candle lit in a dark room. Apparently, he sees no need for a faculty mediating between the light coming from the candle and reflected by the things on the one hand and the seeing organ that receives this light on the other. This understanding of seeing thus presents a possible target against which Sima Biao's somewhat later explanation might have been aimed.

\section{IV}

The last part of our cursory survey of ancient Chinese texts on vision and visuality discusses an excerpt from the Western Han compilation Xinshu 新書 (New Documents) attributed to Jia Yi 賈誼 (c. 200-168 BCE). ${ }^{89}$ The chapter under consideration, 'Explanations about dao and de' (Dao de shuo 道德說 $)^{90}$ is a difficult text replete with problematic details. It resorts to the metaphor of the jadestone to illustrate the six distinctive characteristics or 'traits' ( $l i$ 理) of 'virtue' ( $d e$ 德). ${ }^{91}$ The

$\mathbf{8 8}$ "For these reasons, the Way is to the mind as the fire is to a person's eyes. In the muddle of a deep chamber it is dark; we cannot see. If we set up a bright candle, everything will be bright. This is owing to the brilliance of the fire, not the brightness of the eyes. But the eyes depend on the fire and then can see." (Pearson 1989: 101-102).

89 For a comprehensive discussion of questions of textual transmission and authenticity of the Xinshu, see Svarverud 1998: ch. 1, esp. 1-33; 86-91: "The study of external evidence for the transmission and authenticity of Xīnshū has provided evidence for the extant Xīnshu, overall, being original texts composed by the Hàn eclectic Jiǎ Yí himself or by students or relatives close to him.... Several scholars have claimed the texts to be partly or entirely spurious [...] I would agree [...] with [...] Yú Jiāxī [...] that this evidence is generally superficial” (Svarverud 1998: 91). Svarverud who generally leaves the terms dao and de untranslated (p. xvi), renders the chapter title as "An explanation on the Way and Virtuous potency" (p. 10).

90 The chapter is part of the so-called lianyu 連語-section which gathers texts which are "philosophical in nature" (Svarverud 1998: 35). In Han times, these texts were transmitted independently from Jia Yi's official documents which make up the first part of the extant Xinshu (Svarverud 1998: 150). On the chapters 6 through 10 see Svarverud 1998: 145-149. "The two chapters Liùshù and Dàodéshuō share a passage discussing the six principles of dé, which does not seem to be caused by any garbling of passages but is an expression of a common philosophical basis in these two chapters" (Svarverud 1998: 146). In other words, there is a close connection between these chapters with other chapters that are transmitted in scroll 9 of the Xinshu. For the issue of authorship and date of the chapter see also Csikszentmihalyi 1997: 55-56, n. 23.

91 For a comprehensive study on the jade metaphor in the context of moral education and development in Han China, see the recent paper by Judson B. Murray. His discussion concentrates on Eastern Han thinkers (Murray 2016: 73) and focuses on the image of polished jade (Murray 2016: 93-112). 
very title of the essay suggests that this is a treatise on morality. However, a close reading of the text soon reveals that it actually presents a speculative account of the process of emanation supposedly leading from the dao to the concrete individual things, and that it tries to explain how dao, in spite of its lack of any perceivable form, is still manifest in the motion of these things. This ambiguity of the text, which appears to waver between issues of individual behavior ('techniques') and cosmological processes ('dao'), strikes a modern reader as constantly violating what has come to be called the "fact-value dichotomy".92 However, it should be borne in mind that the opposition of fact and value is distinctly modern, reflecting the historical replacement of a transcendent being as the ontological cause of the Good by the subjective judgement as its moral source. ${ }^{93}$ However, a look at Jia Yi's explication of his term shu 術 ('techniques') makes patently clear that what he attempts to establish is precisely this kind of an intrinsic or essential connection between a universal dao and its concrete particular manifestations which can serve as context-dependent guidelines of our individual actions. This can be seen in the following quote from the 'Dao shu' 道術 (Guidelines of the dao) chapter of the Xinshu, which, as we will see, also resonates in the 'Dao de shuo' chapter under discussion here:

92 Csikszentmihalyi explicitly states that the term shu 術 in the 'Dao shu' and 'Liu shu' 六術 (Six Techniques) chapters of the Xinshu is concerned with "ethics”, just to remark that by reducing ethics to a "technique", Jia Yi "violates the distinction between judgments of fact and of value", which strikes a "modern reader as resulting from fundamental errors of category" (Csikszentmihalyi 1997: 58). Elsewhere, he relates Jia Yi’s “techniques” to "self-cultivation”. Even if he dissolves the alleged "categorical error" by historicizing Jia Yi's writings, this shows a fundamental problem of philosophical discussions of ancient Chinese texts: Obviously, Jia Yi and other Han authors are concerned with problems of governance. And apparently, they address these from within a unified cosmological framework. What for us appears to be a question of ethics or self-cultivation, is first and foremost a way of individual behavior conducive to effective and stable government for them. Far from being determined by individual concerns, let alone subjective judgments, their methods of moral cultivation are aimed at integrating themselves as members of aristocracy or high officials into this all-encompassing whole, which subsumes both the realms of human behavior and of natural processes. Conceiving the problem of individual behavior in ancient Chinese texts as one of ethics and self-cultivation, as opposed to, say, ontology and natural philosophy, thus implies a fundamental anachronism.

93 The philosophical concept of value understood as opposed to the realm of the factual is an innovation of the 19th century. Unlike antique axiology (Hügli 2004: 555), modern philosophies of value base values on subjective judgements rather than claims of existence of a metaphysical Good (p. 557). This specific understanding of value as reflected, e.g., in its opposition to facticity in NeoKantianism, is distinctly modern (Ibid.). However, a short glimpse into the entry on "Value Theory" in the Stanford Encyclopedia of Philosophy (https://plato.stanford.edu/entries/value-theory/, last access 15 June 2020) shows that - probably reflecting programmatic ahistoricism - the historical conditions of the discipline and the very concept of value remain largely unaddressed. 


\begin{abstract}
Dao (leading and moving along) is something that follows from the contact with things. As for its being a root (source), I call it emptiness (= unobstructedness); as for its being the branches (= the various destinations), I call it passages. 'Emptiness' [refers to it] as the subtlety of essence; [as such] it is quiet and pure, without establishing and arranging [things]. 'Guidelines' [refers to it] as what follows from ruling things, it is the calculation [determining] action and rest. Both of these are dao (leading and moving along).
\end{abstract}

\title{
道者, 所從接物也。其本者謂之虛, 其末者謂之術。虛者, 言其精微也, 平素而無設施
} 也。術也者, 所從制物也, 動靜之數也。凡此皆道也。 ${ }^{94}$

To begin, let us summarize what this short quote states clearly: First, dao is characterized as something that only arises following the contact with things. This is obviously related to Jia Yi's observation that dao is unperceivable unless it manifests itself in the movement of things. Second, the passage claims an organic identity between dao and shu (our 'guidelines'), which it respectively identifies as the 'roots' and the 'branches', i.e. the two extremes, of one and the same dao which thus appears to belong to a higher level than the dao conceived in opposition to shu. Third, the passage sets these two poles apart from each other: Viewed as the opposite of 'techniques or methods' (shu) that are applied in concrete situations, the dao is characterized as 'empty'. Eventually, dao and shu are defined as arising from different angles: The opposition of dao and shu is a contrast between an utmost subtlety of essence and a calculation of rest and action that arises only in 'determining' or 'regulating' things. Even if we abstain from further investigating the precise semantics of the key terms involved in this characterization, two points seem clear: First, Jia Yi views dao from the functional perspective of its relation to 'things' - its manifestation depends on the contact with and determination of things. Second, he distinguishes two 'aspects' of dao: In terms of its utmost refinement it is 'emptiness' - and even if it is unclear what precisely this means, this attribute perfectly fits one of the defining properties of dao, namely its unperceivability. Apparently, the purity and clarity of dao is thought to amount in its total transparency and, hence, invisibility. What makes it visible is the traces of the things it sets in motion. In contradistinction from this 'emptiness' characterizing dao itself, Jia Yi then apparently tries to capture the way how it manifests itself in contacting things, how it decides when and where to become active and when and where to remain inactive, or, in his literal rendering, how dao "calculates" between rest and action. It is this specific way in which dao leads things which he calls shu. These shu thus appear to be 'methods' in the sense of concrete pathways or passages through which dao moves the things. This seems to imply that it is only from the perspective of a human who wishes to become an agent of the dao that these particular 'ways of acting and resting' turn into 'techniques' or

94 Xinshu 新書, 'Dao shu' 道術 (8.3/56/9-11). 
'guidelines' to be intentionally practiced and cultivated. Note that there is a metaphorical and paronomastic - and probably even an etymological - link

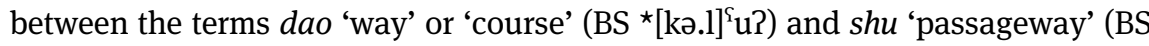
${ }^{\star}$ Cə.lut, Wolfgang Behr: *mə-lu-t): ${ }^{95}$ In quite a literal sense, the shu are conceivable as the passages or the paths through which the "Way" leads the ten thousand things. As dao is thus manifest only in the movement of the things which it is supposed to lead along, we propose the makeshift translation 'leading and moving along'. This isolated quote from the 'Dao shu' chapter tells us little about the specific context in which Jia Yi's conception of the bipolarity of the dao has to be situated. But the following discussion of the 'Dao de shuo' chapter clearly suggests that the metaphors of emptiness, essence, and subtlety in this short passage refer to the eye and to sight, which are thought to reveal the paths for possible action. ${ }^{96}$

When now we return to the 'Dao de shuo', we will concentrate on the extraordinary role which light and vision are accorded in this movement of the dao through things and we will restrict to a minimum our discussion of other issues raised. Jia Yi starts his discussion by an attempt to capture the concept of 'virtue' by attributing it $\operatorname{six}^{97}$ characteristics or traits. His list strikes one as somewhat redundant, and apparently this characterization is not intended to serve as a definition proper. In any case, Jia repeats, as the first two traits of 'virtue' the very terms dao and de - that is 'virtue'. As we shall see further down, the concept of de in Jia's thought is closely tied to the idea of the manifestation of things. Accordingly, we suggest understanding these traits that are named after dao and de as characteristics observable in things. Like this, we could tentatively understand dao as characteristics manifest in their movement, contrasting it from de as referring to characteristics manifest in the forms of these things. As further traits Jia adds 'human nature’ (xing 性), 'spirit' (shen 神), ‘clarity’ (or 'perceptiveness', míng 明) and 'designation' (or 'destination', ming 命) - terms which we shall discuss further

95 Behr 2011: 27.

96 For a discussion of Jia Yi's notion of shu see Csikszentmihalyi 1997, for an alternative (less literal) translation as well as an interpretation of the above passage see pp. 53-54. Csikszentmihalyi also discusses the relation of the notion of shu (techniques) with the mirror metaphor.

97 The fact that the chapter propagates six instead of five virtues has been one of the reasons to deny the authorship of Jia Yi who in other texts appears as a propagator of the number five. Csikszentmihalyi argues that Jia Yi was well aware of the discourse on the five kinds of acts and "added [a sixth] as the signification of the harmonization of the five" (Csikszentmihalyi 1997: 62). This claim of an ultimate unity of the five virtues is also attested in a manuscript found at Mawangdui (Fan 2019: 165). The fact that Jia identifies this sixth notion as 'pleasure' (le 樂 MOC ${ }^{\star}$ râuk; BS *[r] 'awk; LHan *lek < *leuk) appears significant, as it is obviously established on the basis of a paronomastic relationship to the word for 'six' (liù 六 MOC *ruk; BS *k.ruk; LHan *liuk). (MOC = Minimal Old Chinese, according to Schuessler 2009; BS = Baxter-Sagart 2014; LHan = Later Han Chinese, according to Schuessler 2009). 
down. These six characteristics of virtue according to Jia are reflected in the following traits of jade ${ }^{98}$ : 'Shine' or 'gloss' (ze 澤) stands for dao, 'viscosity' or 'fleshiness' (ju 腒) ${ }^{99}$ for de, 'saturation' (zhan run 湛潤), and 'compactness' (hou jiao 厚膠) for human nature, 'fleeting unsteadiness' (poliu 濼流) for spirit, 'luminousness' (guanghui 光輝) for 'clarity', and 'solidity’ (que jian 礐堅) for 'designation'. These "material" characteristics are in turn associated with six "abstract" terms referring to a person's moral constitution. They are listed under the general term of 'beauty' (mei 美) ${ }^{100}$ and specified as dao (道 'exemplary leadership' [?]), 'humaneness’ (ren 仁), 'righteousness’ (yi 義), 'loyalty’ (zhong 忠), 'reliability’ (xin 信), and 'discretion' (mi 密). ${ }^{101}$

Two of the difficulties of Jia Yi's work will become manifest as we proceed: First, while he provides a lengthy list of definitions of moral terms in the 'Dao shu' chapter, ${ }^{102}$ the cosmological vocabulary relevant here is not included there. And in spite of the handful of extremely short "definitions" or rather word glosses Jia adduces, he seems to write his text for a public which, unlike us, is familiar with the meaning of his central terms, some of which seem to be rather technical. Secondly, and not unexpectedly for a Han period text, there is repeated use of paronomastic

98 Discussing the implications of the jade metaphor in Jia Yi's work, Csikszentmihalyi (1997: 62-63; 63, n. 43) notes that moral cultivation entailed physiological change for Han scholars. 99 The text uses the Chinese term $j u$ 腒 'dried meat', which Yao/Zhong 2007: 329 interpret as “symbolizing the 'clarity' (qingxu 清虛) of meat which, drying and contracting, turns into ju”. Others emend 腒 to 榍, a rare word for 'fat, grease' ( $z$ hi 脂). This would fit Jia Yi's phrase “greasy like a sallow cream/ointment” (腒如䊞膏) better. Regardless of its precise meaning, it is clear that the term refers to a first stage in the clotting of a liquid into something solid which is still marked by pale color or semitransparency and a soft consistency, like clotted cream or jelly. Taking into account that the passage refers to meat, ju would seem to refer to lard. (Cf. Yu 2003: 244).

100 Cf. Behr 2020.

101 This set of virtues differs from the one provided in the 'Liu shu' 六術 (Six Guidelines) chapter of the Xinshu, which lists humaneness, righteousness, propriety, wisdom, reliability/sagehood and happiness. The Eastern Han Shouwen Jiezi (henceforth SWJZ) by Xu Shen 許慎 (c. 58-138 CE) also equals a set of qualities ( $d e$ 德) of beautiful jade to six moral characteristics. However, it has only five qualities which belong to a different set (humaneness, righteousness, wisdom, courage and purity; SWJZ 81, p. 10, supra). The 'five kinds of action' (wu xing 五行) are also the subject of the homonymous Guodian and Mawangdui manuscripts (cf. Csikszentmihalyi 1997: 59-62). The set of virtues provided in these texts corresponds to the first five items in Jia's 'Liu shu' chapter, and both manuscripts relate the perfection of virtue to the achievement of 'happiness', but unlike Jia they do not consider 'happiness' itself as one of the virtues (Fan 2019: 165-166). The six virtues presented in the Liu De 六德 (Six Virtues) manuscript from Guodian constitute a different set (sagehood, wisdom, humaneness, righteousness, loyalty, reliability) (Fan 2019: 171). For a comprehensive discussion of Jia Yi's numerological emphasis of the number six and its relation to the five kinds of action, see Fan 2019, esp. pp. 164-173.

102 A discussion with a partial translation of this list is given in Harbsmeier 1998: 60-62. 
figures, which have the obvious disadvantage of broadening rather than disambiguating and limiting the possible range of meaning: This can be seen immediately in the following sketch of the process supposedly leading from the moving dao to the 'fixation' or 'firmness' (ding 定) of concrete things. The passage in question consists of a series of six subsequent sentences which are structurally parallel: The characteristic traits of de are said to 'generate' or 'bring forth' (sheng 生) something which they allegedly 'penetrate' or 'pervade' (tong 通) in a specific way. Unfortunately, however, the very first sentence of the sequence is already an exception with a different syntax. It starts with the semantically ambiguous jian 鑑, whose range of meanings includes 'mirror', 'reflection', but also the totally unrelated 'drill', which we are going to discuss in more detail further down. Jia Yi himself had previously introduced the term jian as an equivalent for $z e$, 'shine' or 'gloss', which he establishes as the defining characteristic of dao. In our discussion of the 'Dao shu' chapter we have suggested that, for Jia Yi, dao is something manifest only in the movement of the things which it is supposed to lead along. $D e$, 'virtue', Jia associates with the manifestation of solid bodies. In view of its paronomastic ties to homophonous de 得 'to receive', common in early Chinese texts, a literal translation as 'taking' or 'assuming shape' would seem possible. However, given that Jia Yi later associates the establishment of definite 'shapes' or 'bodies' (xing 形) with ming 命 ('designation'), we prefer using 'manifestation' for de. To maintain the translation transparent, we also provide the transcriptions.

澤 ${ }^{103}$ 者鑑 104 也, 謂之道. ${ }^{105}$

That which shines is jian (reflecting/drilling). This I call dao (leading and moving along).

103 Yan/Zhong 2007: 329 quote a passage from the 'Pinyi' 聘義 (Meaning of Gift Exchange) chapter of the Liji, which identifies the shine of jade with 'humaneness' (ren 仁): When Zigong suggests to Confucius an "economic" explanation of the preference of the ancients' for jade over alabaster in terms of the scarcity of the former and the abundance of the latter, the master rejects this down-to-earth proposal and instead relates their appreciation of jade to the fact that its various properties represent the different virtues of the gentleman. 'Humaneness' is the first virtue invoked, and it is associated with the smoothness (wen 溫), saturation (run 潤) and shine ( $z e$ 澤) of jade. See Liji, 'Pinyi' (49.11/9-11).

104 Yan/Zhong 2007: 329 point to the 'Dao shu' chapter of the Xinshu where the 'emptiness' or 'transparency' which allows it to "get into contact with things" (jie wu 接物) is illustrated by the image of a bronze mirror (jing 鏡) and a gnomon ( $y i$ 儀) which, in spite of being static, “do neither grasp ( $z h i$ 執) nor store (cang 藏) things”, and yet, when beautiful or bad things arrive, “each is met with adequacy (ge de qi dang 各得其當)”. That the metaphor invokes both the mirror and the sundial shows the ambiguity of ying 景/影 which can be both a shadow as well as a reflection of light.

$105 X i n s h u$ 新書, ‘Dao de shuo’ 道德說 (8.5/59/1). 
A few lines further down, Jia continues:

鑑生空竅而通之以道, 德生理通之以六德之畢離 ${ }^{106}$ 狀。( ...)。性生氣而通之以曉, 神生變而 通之以化, 明生識而通之以知, 命生形而通之以定。 ${ }^{107}$

Jian (reflecting/drilling) brings forth an empty hole (hollow cavity) and pervades it by dao (leading/moving along); de (manifestation) brings forth traits (li) and pervades them with the patterns of the netted threads of its six virtues (de). (...) Human nature brings forth breath and pervades it with luminousness. Spirit brings forth changes and pervades them through transformation. Clarity brings forth perceptions and pervades them through knowledge. Designation brings forth bodies (shapes) and pervades them through fixation [of their position].

In spite of its tentative character, the above translation shows that the text stages the six characteristics of de in two different and subsequent functions: after generating something different from themselves, they subsume it by pervading or integrating it in a specific manner. And even if some of the steps seem not all too clear, the overall sequence obviously advances from the establishment of a path for movement ("holes" for the moving dao, "traits" that cross de, animating breath filled with light, transformations penetrated through change - in awareness [?]) to the consolidation into definite entities (perceived distinctions integrated into our knowledge, shapes or bodies which are designated and thereby fixed to a certain place or position - arguably both spatially and taxonomically). It is clear that this short passage is fraught with many uncertainties and that an attempt to analyze it in due detail would certainly go beyond the scope of the present paper. However, before continuing, it seems necessary to have another look at the problem of ambiguity and paronomasia. As seen before, the above sequence starts with an irregularity: While five of the six consecutive sentences illustrating the stages of subsequent developments all begin with a statement about one of the six characteristics (li) of de (namely de, xing, shen, ming, and ming) and its role in the generative process bringing forth the world of things, the initial sentence that represents the first step does not start with dao, as one would expect, but with the difficult term jian. The most common meaning of this word, which is doubtlessly invoked at least in parts of the text which follows, is 'water mirror', and, possibly

106 畢 $b i$ is a net: “The form of a net in which all threads are separated from each other and yet tied into a net, this is like '[the traits of] de bringing forth a pattern (li)"' (Yan/Zhong 2007: 330). The established meaning 'handline' for gang would yield another image with the threads of the net being connected to a single handline. According to Yu 2003: 244, the expression bili 畢離 means 'uneven'. Yu's modern Chinese translation renders the respective passage as “[...] virtue (de) produces a mechanism which pervades the manifestation of the six virtues (de) in an uneven manner" (Yu 2003: 246). At the same time, he also interprets $l i$ 離 as "mutual connection of the threads in a net (wangluo 網絡)” (p. 246).

$107 X i n s h u$ 新書, ‘Dao de shuo’ 道德說 (8.5/59/3-5). 
derived from this concrete sense, the (secondary) verbal meaning of 'reflecting'. Yet, while this meaning seems perfectly adequate in the subsequent parts of the text, the metaphorical relation between "water mirror" and the idea of a "hole" or "cavity" seems somewhat elusive: This elusiveness results from the specific metaphor which Jia Yi chooses for illustrating the function of dao. Note that he is comparing the process of the cultivation of one's de to the abrasion of jade. ${ }^{108} \mathrm{In}$ this context, jian, sometimes written with the semantic determiner stone, has another meaning, apparently unrelated to reflection: It stands for an awl or whetstone used for drilling jade. In the Lüshi Chunqiu, it is presented as the prototypical tool used for boring the holes in the middle of circular bi jade disks. ${ }^{109}$ In other words, with regard to the example of the jadestone, the interpretation of jian as a drill makes good sense. Possibly, it is also relevant to consider that jade was abraded by means of a mixture of water and sand which made the wet stone shine - and, $z e$ 澤, the kind of brilliance invoked here as a characteristic of dao usually stands for the sheen or gloss of wet objects. ${ }^{110}$ The image thus seems to suggest that sanded jade in a way keeps the brilliance which is typical for things that are wet or seen through water. The meaning of jian 'awl/whetstone' thus provides a couple of semantic connections which seem to allow for a paronomastic association with homonymous jian 'water mirror/reflection'.

Turning to the literal referent of the metaphorical hole that is said to be drilled, we first note that the term qiao 憿 that occurs in Jia Yi's formulation “kong qiao" is a

108 Murray argues that the metaphors of jade and the water mirror refer to two different and antagonistic approaches to personal cultivation. On his view, jade stands for a way of moral development that relies on "active, accumulated learning" whereas the water mirror represents a "contemplative way [...] directed at safeguarding natural inner cognitive and affective faculties" (Murray 2016: 76). In light of this, Jia Yi's text seems innovative in that it tries to combine and correlate both metaphors - by means of a paronomastic reinterpretation of the crucial term jian (also 'water mirror'). Murray himself observes that the metaphor of (uncut) jade is sometimes also linked with the same concept cluster that is usually associated with the water mirror (Murray 2016: 80). Taking notice of the Xinshu passage under discussion here, he remarks that vigilant selfexamination "is one undertaking where the images of polished jade and the water mirror converge on common ground for a shared purpose” (Murray 2016: 105).

109 Huainanzi, ‘Shuo shan xun’ 說山訓 12: “Jade relies on an awl to become an artifact. And yet there are jade discs worth thousands of tael, but there is no awl that would be worth even an eighth of a tael or a sixteenth of a catty” (玉待礛諸而成器, 有千金之璧, 而無錙錘之礛諸 [16.81/161/ 18-19]).

110 The Shuowen Jiezi (no. 7183, SWJZ, p. 231, infra) defines zé 澤 as "bright (lit. lightful) and drenched' (guang run 光潤) and the Shiming ('Shi shui' [Explaining water], [1.4/10/16]) remarks that "the place where water is spilled and which becomes wet is called a puddle (zhang 掌), [as] the place where the water stands still is like the palm (zhang) of the hand. (水泆出所為澤曰掌，水停處 如手掌中也), which is an obvious paronomastic gloss possibly alluding to yet another pun, namely the one connecting the word $z e$ 'wet' to $z e$ 擇 'to pick; to seize; to ladle [water]'. 
common designation for the nine orifices of the human body to which the two eyes belong. ${ }^{111}$ In contrast, the image of the water mirror, the second meaning of jian, in spite of its obvious relationship to sight and vision does not provide any straightforward and unambiguous point of reference for the imagery of the hole. And even if we consider the idea, common in ancient Chinese texts, that the heart is located in the cavity of one's chest and filled with a waterlike purified essence (jing), this sense of a hole as a container is considerably different from the meaning of a hole as a passage invoked here. Focusing on the function of orifices as gateways that connect the body with the outer world, and keeping in mind that the light metaphor Jia Yi invokes here doubtlessly refers to the eyes, the following observation seems to be of some relevance for our case: Despite the lack of evidence for the use of lenses for magnification in early China ${ }^{112}$, some Han texts testify to the existence of the use of observation tubes with a "magnifying" effect, ${ }^{113}$ though we may assume that the impression of the enlargement of the observed object was in fact a consequence of a gain in visual acuity due to the avoidance of stray light. We also know that the later Mohists described the inversion of the image in the concave mirror, and, according to influential voices, in the camera obscura $^{114}$ - even if they apparently gave the wrong explanation of the

111 Yan/Zhong 2007: 330 support this. They identify kongqiao as referring to the eyes.

112 Laufer holds that even burning lenses were unknown in ancient China and attributes respective claims to "a fallacy due to misunderstandings of the texts" (Laufer 1915: 180). He is doubtless right in pointing out that the terms yangsui 陽燧 and fusui 夫燧 refer to burning mirrors rather than lenses (pp. 182-183). All examples of igniting fire by means of sunlight in the transmitted text of the Huainanzi clearly refer to mirrors. However, the case seems to be different with a fragment from another compilation attributed to the prince of Liu An, which discusses the use of ice lenses for the purpose of lighting a fire. See n. 159, pp. 44-45 below. It is thus at at least questionable if Laufer is really right in attributing the knowledge of lenses in China to Indian influences (p. 188), the first evidence for burning lenses made of crystal (huozhu 火珠) being available in accounts on tribute gifts from the early 7th c. CE in Jiu Tangshu (Former History of the Tang, compiled in the 10th c. CE, pp. 208-209; 214). These lenses were of Indian origin (p. 216-217; 225).

113 Shuoyuan, 'Bianwu' 辡物 28 (18.28/159/15) (“The larger what you focus on, the lesser what you see”) 所窥者甚大，所見者甚少 ); slightly varied in Han Shi Waizhuan 10.9 (10.9/74/12). However, as Laufer has long noted, there seems to be no evidence for magnifying lenses in antiquity, both in China and in the Mediterranean. The reason for the magnifying effect of a magnifying glass sphere filled with water "was sought [...] not in the spherical shape of the glass, but in the water with which it was filled." (Laufer 1915: 176).

114 The interpretation of the crucial passage in 'Canons' and 'Explanations' of B 19 ("The inversion of the image has its initial point at the intersection point and translates onto an image screen [...]” 景到在午有端與景長 (Canon) “[...] Therefore the (inverted) image is inside the chamber” (Explanation) 故景庫內也) hinges on delicate interpretations and emendations on the word level (Graham 1978: 375-378). "B 23 explains what happens when [images] are inverted in the concave 
effect. ${ }^{115}$ It thus does not seem entirely implausible that Jia Yi imagined the eye in analogy with a peephole or even a camera obscura. Yet, as exciting as this would be, it is clear that our text does not provide enough evidence to support such farreaching speculations. Possibly, the image of the water mirror points into another, less spectacular direction: We have already seen in our discussion of Wang Chong's explanation of optical hallucinations, that he seems to conceive the eye as a container of a "water-clear", that is, transparent, substance he calls jing, translated as “essence” above. This same imagery is attested also in the Ling shu jing 靈 樞經, a medical classic whose earliest parts can be traced back into the 2nd century BCE. ${ }^{116}$ It describes the eye as the reservoir of the most refined essence from all five inner organs. ${ }^{117}$ The comparison of the heart-mind (xin), and the eye, sometimes dubbed as its “seal" ( $f u$ 符 $)^{118}$ or "surface" $(f u \text { 浮 })^{119}$ in ancient texts, ${ }^{120}$ with a pan of water is also familiar from the description of false perception in the 'Jiebi' 解蔽 (Dissolving obscurations) chapter of the Xunzi 荀子. ${ }^{121}$ And a "large pan of water" is precisely the gloss which the 2nd century CE Shuowen Jiezi 說文解字 (Explaining Unit Graphs and Analyzing Compound Characters) gives for jian 鑑. ${ }^{122}$ While there are uses where the term clearly refers to bronze mirrors, notably so in the optical sections of the Mohist 'Canons' and 'Explanations', most of the few instances

mirror. It is conceivable that the author of the present Explanation (i.e. B 19, R.S.) preferred to illustrate the phenomenon by the example of the camera obscura, but if so one would expect a much more explicit indication of the concrete situation than any commentator has been able to find" (p. 377). For the same Canon (identified as B 18), see also Graham/Sivin 1973: 120-125. For the discussion on the pinhole camera and Graham's alternative interpretation - of which Nathan Sivin remained unconvinced - see pp. 123-125.

115 Graham 1978: 377. On a discussion of Mohist optics in the larger context of moral cultivation, see Nylan 2008: 19-32.

116 Unschuld 2003: 3; 352, n. 14. On the role of shen see p. 9.

117 Ch. 80 'Da huo lun' 大惑論 (On major delusions), see n. 67, pp. 15-16 above.

118 Hanshi waizhuan 4.5 (4.5/27/2).

119 Da Dai Liji, 'Zengzi lishi’曾子立事, 37 (4.1/27/14).

120 The intimate relationship between the 'heart' and the 'eye' is also exemplified in the following passage from Suwen 素文, 'Jie jing wei lun’ 解精微論, 2: “The heart is concentrating the essence from the five inner organs. The eye is its orifice. Expression and color (of the eye) are its (the heart's) brilliance. Therefore, when a man has de (a benefit; virtue?), the balance of his breath-matter is in his eyes; if he has losses, the sorrow can be known from the color (of his eyes)”. (夫心者, 五藏之專 精也, 目者, 其竅也, 華色者, 其榮也, 是以人有德也, 則氣和於目, 有亡, 憂知於色。) For a translation, see Unschuld 2015: 624.

121 Xunzi, 'Jiebi' 10 (21/105/5-6); 12 (21/106/7-8).

122 Shuowen Jiezi, no. 9245 (SWJZ, p. 294, infra). 
clearly refer to the reflection of shapes on the surface of water. ${ }^{123}$ Together with our previous observation that the "essence" concentrated in the eye is described like a liquid, this suggests that it is indeed the water mirror to which the metaphor of jian in the present context refers: The idea of the cavity of the eyes thus does not so much invoke the image of vacuity or emptiness than that of transparency: Indeed, it is this feature of the clarity of water which the mirror metaphor in our context refers to. At the same time the paronomastic progression from the image of the awl to the water mirror has alerted us to the possibility that words in Jia Yi's text are not used with one single meaning. The ambiguity of jian wavering between the meanings 'drill/awl' and 'water/bronze mirror' thus appears to be an intentional device for bridging the imageries of the abrasion of a piece of jade by means of a whetstone and the eventual reflection of light by a polished piece of jade. In obvious analogy, the process of cultivating oneself eventually culminates in the accomplishment of one's personal 'virtue' (de). We have thus reached the point where the cosmogenetic process is related to the ontogenetic process - and where the natural translates into the moral. After all, moral perfection and charisma manifest themselves in individual human beings.

After his initial allusions to the process of polishing and drilling jade, Jia Yi seems to change from a metaphorical to a more literal mode of expression: The following passage, rather vague and difficult to grasp not least due to its figurative diction, paves the ground for Jia Yi's disquisitions on the eye. Yet, before mentioning the organ of sight itself, Jia presents a characterization of dao, literally the "way", the first of his six distinctive traits (li) of de:

\begin{abstract}
Dao (leading and moving along) has no shape (body of its own), balancing and harmonizing [things] it acts spiritlike (i.e., invisibly). When it moves things, it has things on which it rides (embarks), holding them together as if in a net, by having each follow its track, harmonizing and adapting their course. Therefore, things have their clarity and shine.
\end{abstract}

道者無形, 平和而神。道物 ${ }^{124}$ 有載物者, 畢以順理和 ${ }^{125}$ 適行。故物有清而澤。126

From the second sentence it seems clear that dao in spite of its literal meaning here neither refers to a way in the sense of a path nor to any concrete object at all. Rather, it is something which affects things and which, in doing so, still relies on

123 E.g. Zhuangzi, 'Dechongfu' 德充符, 1 (5/13/18): “Nobody sees his mirror image in flowing water, but only in still water ....” (人莫鑑於流水, 而鑑於止水。). With parallel passages in Huainanzi, ‘Chuzhenxun' 俶真訓, 17 (11/16/9) and Wenzi, 'Shouqing' 守清, 1 (3.5/15/5-6) (writing 流沫, 'flowing spume' / 止水 and 流潦 'flowing rivulet' / 澄水 'clarified water', respectively).

$124 \mathrm{Yu}$ Yue deletes 物 as an interpolation (Yan/Zhong 2007: 332).

$125 \mathrm{Yu}$ Yue deletes 和 (Yan/Zhong 2007: 332).

126 Xinshu 新書, 'Dao de shuo' 道德 說 (8.5/59/14). 
them, literally 'embarks' or 'rides' on them: This suggests that dao here refers to the movement of things. When dao leads them on their way, it is only traceable, for an external observer, from the path these things take. Like this, it is reflected in the entire web of coexisting things which it has follow their specific tracks or channels and adapting to their particular way of moving or advancing. Insofar as dao is only traceable from the movement of the things, which, as we learn from the short passage, it is thought to set in motion, it is an invisible driving force comparable to a spirit. And it is precisely because dao is reflected in the course of the entirety of things, that it maintains the balance and harmony between them. However tentative our interpretation of this extremely dense passage has to remain at this point: It is obvious that it presents a clear and consistent picture. This is less clear when Jia Yi takes his next step: The things, he writes in the third and final sentence of the passage, which dao leads on their way, possess both clarity and brilliance. It is rather from what follows than from Jia's initial characterization of dao that we propose that by these terms he refers to an inherent property or characteristic of the things that move by virtue of dao, rather than to dao itself. But what does it mean to say that things have their clarity and shine? Jia attempts to illustrate it in the following way:

The shine is what is reflected. And by reflection [dao] leads them [=the things]. Spirit aligns the shapes of things by models, passing and pervading the hollow [= transparent] cavity. Unifying, in its receiving function, the outgoing and the incoming [light?], it precedes [both]. Therefore, I call it reflection. ${ }^{127}$

澤者鑑也, 鑑 ${ }^{128}$ 以道之, 神模 ${ }^{129}$ 貫物形, 通達空竅, 奉一 ${ }^{130}$ 出入為先, 故謂之鑑。 ${ }^{131}$

$127 \mathrm{Yu}$ 2003: 248 translates: “[Its] brilliance is something which enables [it] to reflect things, using the reflection of shapes it mysteriously leads without being discernable itself, imitating in its reflection the forms of things. That in its penetration it is like the mouth or the eyes of the human body, which have the veneration of $d a o$ as their leading principle, is why we call it "mirror'." Obviously, Yu interprets the passage as Jia Yi's explanation why he chooses the mirror as a metaphor for dao rather than as a description of process of seeing.

128 Written as 監 in the Yan/Zhong edition (2007: 333).

129 Yan/Zhong (2007: 333) have 摹 instead of 模 and indicate that one edition writes 摸 'to inspect/trace'.

130 The numeral 'one' is commonly interpreted as referring to the unity by which, according to the Shuowen Jiezi, dao is established (Yan/Zhong 2007: 333): "The One is the great commencement at the beginning; the dao is established out of the One, in creating it splits into heaven and earth, in changing it accomplishes the ten thousand things.“(一惟初太始，道立於一，造分天地，化成萬 物; SWJZ, p. 7, supra). Yu's translation implicitly adopts this interpretation and replaces - by 道 (Yu 2003: 248).

131 Xinshu 新書, ‘Dao de shuo’ 道德說 (8.5/59/14-16). 
While the entire passage is not easy to understand, there are a couple of places which pose especially thorny problems: First, it is not clear, whether the two verbs related to the emission and reflection of light (ze and jian) refer to an activity or to an object displaying them: Does Jia say that brilliant things reflect or simply define that brilliance is reflection? Second, and more importantly, it is not clear, how the sequence “dao zhi shen” (道之神) is to be analyzed. In the above translation, zhi is taken as the object pronoun and referred to the things on which the previous passage says that they are led by dao. This implies an interpretation of the character 道 as a transitive verb, that is, it has to be read as dăo ( ${ }^{\star} l^{\complement} \mathrm{u}$ ?-s), often written with the character 導. It is moreover implied that the agent that "leads by reflection" is different from "spirit", which is said to delineate and go through the things which appear to it. Another parsing would take the expression as one single phrase and interpret $z h i$ as a marker of adnominal determination ("genitive"): Like this, the spirit would be an attribute of the leading force called "dao", and the clause would yield something like "They [the things?] reflect through the spiritlike (= invisible) activity of the dao (...)". ${ }^{132}$ Two things speak in favor of the first analysis: First, this interpretation would provide us with a clue to why the previous sentence connects the idea of leading things with their property of emitting and reflecting light: that the things that emit light are reflected by other things which thereby are able to orient themselves accordingly. A second, and probably stronger, reason for favoring the first segmentation is the fact that it is the word shen 'spirit' (LHan *źin; MOC *m-lin; BS *Cə.li[n]) which is resounding in the parono-

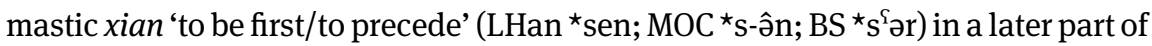
the argument. This suggests that the passage centers on 'spirit' rather than dao. ${ }^{133}$ While kongqiao in the next passage is attested in the sense of a cavity of a sense organ elsewhere, ${ }^{134}$ the meaning of "feng yi chu ru" is not self-evident. Since the

132 This is the interpretation suggested by the punctuation in Yao/Zhong 2007: 324.

133 The alternative would be jian 鑑 which would nicely match xian 先 in Mandarin, but which differs both in the onset and the coda in MC as well as earlier stages of Chinese (MC/LHan ${ }^{\star}$ kamC; MOC *krâms; BS^[k] $]^{\uparrow}$ rams).

134 Huainanzi, 'Jingshenxun’ 精神訓, 4 (7/55/27) and Wenzi, 'Jiushou’ 九守, 2 (3/13/6) characterize kongqiao (replacing 空 by 孔), literally 'cavities and orifices' as the "doors and windows of essence and spirit” (孔憿者精神之戶牏). These two terms occur in Laozi 47, and Han Feizi ('Yu Lao' 喻老, 17; 21/44/30) also uses the term kongqiao (空憿) as their equivalent, warning that "when ear and eye are used up by sound and color, when essence and spirit are used up by external forms, this is because there is no lord inside.” (耳目竭於聲色, 精神竭於外貌, 故中無主). What is interesting for us is less Han Feizi's appeal for hierarchy than the fact that the text associates three causes of exhaustion, not only sound and color, but also 'external marks' (waimao 外貌). Possibly, the second clause is not adding a new dimension, but captures into one general term what exhausts ear and eye, namely external marks present in color and sound. Kongqiao 空竅 is generally rare, but it occurs four times in the medical classic Ling shu mentioned above. 
passage deals with reflection, one could argue that it refers to the fact that the surface, which reflects, in a way throws back and hence "emits" the beam of light whose immission it had previously received. In this sense, the reflecting surface turns immission into emission and thus unites the two in itself. The fact that feng as a verb in its literal sense can refer both to the respectful reception and offering of gifts, i.e. it is not semantically fixed as to the direction of the interaction, seems to support this interpretation. The spirit, which through reflection of the incoming light depicts the illuminated (or illuminating) things in front of it, thus would mark the point where the incoming light is turned into outgoing light. Like this, it would be there before any light enters or leaves, or, in the words of our text, it precedes the reflection of light. Whether or not this rather far-reaching interpretation is correct: It certainly succeeds in making sense of the phrase in its larger context.

Eventually, a final word needs to address the problem of the concluding sentence: Why does the privileged position of "spirit" justify calling it jian? On a manifest level, it is difficult to make sense of this claim, which is somehow presented as a crucial statement resulting from the previous description of its function. However, the situation looks different if we consider the possibility that we are facing yet another instance of an etymological argument: Technically, the previous statement - at least in our interpretation of incoming and outgoing light - simply is a concise gloss of what reflection is. However, reflection had been mentioned before in the text, and it seems unclear why it should be repeated and given additional emphasis. In view of this, I suggest that the term jian here connotes near homophonous jiān 監. (MOC: krâm; BS: *[k] ${ }^{\complement}$ ram), which, among other things, means 'to inspect', 'to supervise', or 'to procter' ${ }^{135}$ Etymologically, jiàn (krâms; ${ }^{\text {` }}$ ram-s) 'to mirror' is an endoactive derivation from this verb, ${ }^{136}$ and the character - showing a person with an oversized eye looking down into a water $\operatorname{pan}^{137}$ - can also be used for writing endoactive 'to mirror'. The addition of the semantic determiner 金 thus seems to result from a later attempt to disambiguate

135 "Endoactive" jiàn, written 監, is attested already in the earliest layer of the transmitted literature. Thus in the 'Jiugao' 酒誥, 8 (Announcement on Wine) chapter of Shangshu 尚書 (Venerated Documents), the king quotes an ancient saying which goes as follows: "No man is mirrored by water; he must be mirrored by other men” (人無於水監, 當於民監 [38/35/3-4]). This appears in the ruler's admonition that nobody including his listeners is able to inspect himself and hence relies on being inspected by the king. Murray's interpretation of the passage differs somewhat: He relates it to the situation that other people "provide examples of worthiness to emulate" (Murray 2016: 106).

136 Cf. Schuessler 2007: 305. Schuessler further suggests that the comparatively late jing 鏡 also derives from the same root via "re-etymologization" (p. 319). On the s-suffix as indicator of endoactive (Schuessler: 'exopassive' verbs see Schuessler 2007: 41-42; Gassmann/Behr 2013: 458-459; Baxter/Sagart 2014: 59).

137 Guwenzi gulin, vol. 7, pp. 540. 
these two etymologically related meanings of 'inspecting' and 'mirroring'. Instead of simply repeating what has already been stated, namely that the text sets out to discuss the phenomenon of the reflection of light, it thus underlines the extraordinary role of 'spirit' as the 'gatekeeper' which checks everything that arrives at the eye before it allows it to enter the body.

Arguably, there is another reason why Jia characterizes 'spirit' as what is 'preceding' or 'going ahead': The Shuowen Jiezi defines 'spirit' as that "which leads out the ten thousand things” (yin chu wan wu 引出萬物). It has been suggested that this definition is a paronomastic gloss which relates shen ${ }^{\star}{ }^{*} \mathrm{~m}-1 \mathrm{lin} / \mathrm{MOC}{ }^{\star} \mathrm{m}-\mathrm{lin} / \mathrm{BS}$ ${ }^{\star}$ Cə-li[n]) to yin 引 'to pull, lead on' (*lin-q/MOC lin?/BS ${ }^{\star} \operatorname{li}[n]$ ) $){ }^{138}$ There are several passages in ancient Chinese texts which use this word for capturing the interaction between the 'spirit' or its bodily abode, the 'heart', with the 'things' outside. Whatever its nature, the link between shen and yin is thus obviously not an idiosyncrasy of the Shuowen Jiezi. ${ }^{139}$

The close connection Jia Yi establishes between the eye and the way, between eyesight and orientation, that is, the definition of the way which our eyes lead our feet to walk, is characteristically expressed in the following portrayal of the

138 Behr 2010: 9.

139 The following passage from the Huainanzi, ‘Chuzhen xun’ 俶真訓 (Instruction on Preserving Truth) belongs among the more explicit cases in point: 外從其風, 內守其性, 耳目不燿, 思慮 不營。其所居神者, 臺簡以遊太清, 引楯萬物, 群美萌生。是故事其神者神去之, 休其神者 神居之。“ Outwardly, he follows their (= the changes) way (lit. 'winds'), inwardly he keeps his nature intact. His ears and eyes are not clear, his thinking and planning are not busy. As for the spirit which he houses, he sticks to simplicity so that it roams in highest clarity, pulling and barring the ten thousand things, so that the sprouts of the many beauties (= virtues) arise. For this reason, those who engage their spirit - spirit is leaving them; those who have their spirit rest - spirit is housing in them." (2/12/22-23; for an alternative translation, see Major et al. 2010: 92). Gao You's 高誘 Later Han commentary glosses shun 楯 as zhuo 擢, i.e. a synonym of 引, 'to pull' (cf. Huainanzi Jiaoshi, p. 142; p. 171, n. 37). However, the meaning of 楯 'to bar/to shield off' also makes perfect sense here. Apparently, shen is an agency that is thought to be able both to 'pull/draw close' external things and to keep them away. Moreover, passages such as Mengzi, 'Gaozi I' 告子上 (11.15/60/27 - 61/1) or Xunzi, 'Jiebi' 10 (21/105/7-8) - even if only speaking about the heart, the abode of the spirit, rather than directly mentioning spirit itself - suggest that this 'pulling' was considered reciprocal. Just as our own spirit was thought to be able to attract external things, there was a concern that things might 'pull out' or 'pull away' our spirit - thus the Mengzi warns us that 'things' might 'distract', literally 'pull away', the sense organs, and the Xunzi notes that even a small thing may 'pull' the heart. There is thus a conception of an exchange of spirit. And the Huainanzi seems to alert us that too much sensing and thinking might lead to a loss of concentration of spirit - in a quite literal sense. A similar passage about protecting spirit from being attracted by external things can be found in Han Feizi, 'Jie Lao' (20/ 41/20 - 42/1). 
junzi 君子 transmitted in the Guoyu 國語 (Discourses of the States) ${ }^{140}$, Hanshu 漢書 (History of the Han), and, in a slightly shortened version, Jia Yi's Xinshu ${ }^{141}$ as well:

\begin{abstract}
Now as for the gentleman, it is his eye by which he fixes his body, and it is his feet by which he follows it (= the eye); Therefore, when you look at his face, you definitely know his heart. It is the eye by which he positions what is appropriate (for him), and the feet by which he walks (according to) his eye. The sight of the Marquis of Jin reaches far and his feet carry him high up, his eye does not orient (literally "cause to be in a particular place") his body, and his feet do not walk (along) his eye. His heart must be strange! He whose eye and body do not follow each other, how could he endure?
\end{abstract}

夫君子目以定體, 足以從之, 是以觀其容而知其心矣。目以處誼 ${ }^{142}$, 足以步目。晉侯視遠 而足高, 目不在體, 而足不步目, 其心必異矣。目體不相從, 何以能久? ${ }^{143}$

The passage, it seems, attributes the function of a compass of one's body to the eye. There is thus a very straightforward sense in which the eyes are of an extraordinary importance for our way. Quite possible that this simple fact stands at the beginning of Jia Yi's lofty speculations about the Way and the process of its manifestation. It is also worth noting that, incidentally, the orientation of one's path according to a particular object is, in some variants of this pericope, rendered as ding 定 'to fix' (rather than zheng 正 'to adjust'), that is precisely by the term which Jia Yi had associated with the sixth characteristic (li) of de, namely ming 'designation', as discussed above. So far, it has remained unclear what it is that is thought to be fixed here. A precious hint pointing at a possible clarification of this question can be found in the Eastern Han Shiming 釋名 (Explaining Terms) where, in the section on illnesses and diseases, there is the following passage:

If the pupils are bright (clear) but unfocused (lit. not aligned), this is called pervasive vision; these words mean that (vision) pervades and encompasses the eyeholes as a whole. One also calls this 'pairwise (lit. harnessed) vision': 'pairwise' is separate. One says one eye looks at the sky, the other at the ground, so that the clarity (brightness) of the eye is split apart and what [the two parts] see is not the same.

眸子明而不正曰通視, 言通達目匡一方也。又謂之麗視, 麗, 離也。言一目視天, 一目視 地, 目明分離, 所視不同也。144

As a verb combining with ming, 'clarity' or 'brightness', that is, the faculty of seeing, zheng here refers to grasping a thing in the visual field by focusing one's

140 Guоуu, 'Zhouyu xia' 周語下, 25 (1.25 / 15/28-16/1).

141 Xinshu, 'Li rong yu xia’ 禮容語下, 7 (10.2/72/18-20).

142 Guoyu has 義 instead of 誼 $(1.25 / 15 / 28)$.

143 Hanshu 漢書, 'Wuxing zhi’ 五行志 (Records on the Five Phases), 7 (Hanshu, p. 1354).

144 Shiming, 'Shi ji bing' 釋疾病, (8.1/86/13-14). 
eyes on it. Interestingly, the unfocused way of vision, which conveys an indistinct brightness, is associated with the word tong, to pervade or penetrate. Focusing a thing, we fix the position of the thing before our eyes and determine the route we would have to take for reaching it. This is further and independent evidence for the collocation of some of the key terms of the 'Dao de shuo' in the specific context of positioning and fixing a thing in vision. The emphasis, in Jia Yi's conception of the notion of $d e$, on the importance of the eye for fixing one's aim and thus defining one's path is somewhat reminiscent of the very shape of the character 德 de (MOC ${ }^{\star} \mathrm{t} \partial \mathrm{k} / \mathrm{BS}{ }^{\star} \mathrm{t}^{\mathrm{f}} \mathrm{\partial \textrm {k }}$ ) (and variants based on 直 $z h i$ [MOC * $\mathrm{dr} \mathrm{k} / \mathrm{BS}{ }^{\star} \mathrm{N}-\mathrm{t}<\mathrm{r}>\partial \mathrm{k}$ ], obviously the character's phonophoric), which combines the elements chi 彳, indicating movement, with 直, which consists of 目, 'eye', along with a 十-shaped element that corresponds to a single vertical line in some archaic character forms and has hence been identified with the sight line allowing one to adjust and straighten oneself ${ }^{145}$ This has even led to speculations that the character originally wrote a word meaning something like 'to look directly at something, ${ }^{146}$ Jia Yi's philosophical or cosmological reconstruction of the term - in spite of its apparent novelty - thus looks like a "learned" folk-etymology of the character's graphic structure.

Let us return to the discussion of reflection and sight in the 'Dao de shuo' which continues as follows:

Reflection is that whereby one is able to see. What sees is the eye. When dao (moving/leading along) and de (manifestation) arrange things, essence sublimates and constitutes ${ }^{147}$ the eyes. $^{148}$

鑑者所以能見 ${ }^{149}$ 也, 見者目也, 道德施物精微而為目。 ${ }^{150}$

Like Wang Chong, Jia Yi here also seems to distinguish between reflection - that is the light emitted or reflected by external things - as the cause of seeing and the eye

145 This analysis is proposed by Xu Zhongshu 徐中舒 (1989-1991) (Guwenzi gulin, vol. 2, p. 474). Wolfgang Bauer even writes about speculations identifying this element as a thunderbolt emitted from the eye, unfortunately without providing a source. See Bauer 2001: 93.

146 Cf. Barnwell 2013: 5.

147 The semantics of wé $i$ 為 connote both the physical process of this essence condensing into the eyes and the function of essence in this configuration as the organ of sight.

$148 \mathrm{Yu}$ Zhirong translates: "A mirror is able to duplicate the shapes of the ten thousand things, and what is able to spot the ten thousand things is the eye. When it comes to dao and de functioning inside external things, the most refined and subtle is the eyes." (Yu 2003: 248-249).

149 見 is an emendation by Lu Wenchao 盧文弨 (1717-1795). Liu Shipei 劉師培 (1884-1919) rejects this emendation, arguing that neng 能 stands for tai 態, which he interprets to refer to a mirror's manifestation of the shapes of things (Yan/Zhong 2007: 333).

150 Xinshu, 'Dao de shuo' (8.5/59/16). 
as the faculty able to see. While it is clear that the eye is characterized as the most sublime form of essence (jing 精), ${ }^{151}$ the preceding phrase about the activity of dao and $d e$ is not very clear. What shi 施 here most probably means is made explicit in a passage transmitted both in the Huainanzi and in the Da Dai Liji 大戴禮記 (Record of Rites by Dai the Elder) which relates it to sources of light like the sun or fire which emit ( $t u$ 吐) breath (“animating matter”, qi) - as opposed to things like water or metal which are said to absorb (han 含) it. ${ }^{152}$ These usages of shi thus refer to the projection of light and its concomitant translation into the shape of a specific reflection (ying 景).

Therefore, when things first take shape [= assume their body], they [dao and de] partition [some of] the preceding [= spirit] to become the eye. When the eye is completed, the shapes (bodies) follow. Hence, when it comes to having a basis in breath-matter as a human, none is more refined than the eye. The eye is clear, just as shiny and brilliant as a liquid, without there being any dirt and dust intermingled with it. Therefore, it is able to see. Seen from this perspective, the eye is sufficient to see clearly (have clarity about) the [inner] sheen and [outer] brilliance of dao (moving/leading along) and de (manifestation). ${ }^{153}$

是故物之始形也, 分先而為目, 目成也, 形乃從。是以人及有因之在氣, 莫精於目, 目清 而潤澤若濡, 無重穢雜焉, 故能見也。由此觀之, 目足以明道德之潤澤矣。154

Although it is unclear in what larger context this passage has to be situated, the description could well refer to the ontogenesis of an individual human being. Interestingly, the eye of the person is thought to precede the shapes - as, apparently, it is only through reflection, that is, through the eye that shapes or forms first appear. However, the description also resembles depictions of the emanation of the world through subsequent stages of ever increasing concreteness in cosmological speculations transmitted in the Huainanzi and in Han apocryphal texts attributed to Zhouyi 周易 (Changes of Zhou) traditions. These writings describe an advancement through the consecutive stages of complete vacuity ( $w u$ 無),

151 When the Shiming ('Shi xing ti’ 釋形體 [Explaining the body and its parts], [2.2/19/13]) discusses the pupil (tongzi 瞳子), it identifies the suffix - $z i$ 子 as a “diminutive” (小稱) and further remarks that the minuteness thus indicated "mainly refers to what is most refined and bright” (主 謂其精明者), i.e. to the essence concentrating in one's eyes.

152 Huainanzi, ‘Tianwenxun’ 天文訓, 2 (3/18/28-30); Da Dai Liji, ‘Zengzi Tianyuan’ 曾子天圓, $2(5.5 / 35 / 4-9)$.

153 "Therefore, when, at the beginning, the ten thousand things are provided with their bodies, it is the eyes which first discern clarity. Things (wuti 物體) are only formed after the eyes have been formed. All the breath-matter ( $q$ i) on which human beings rely becomes more complete through the presentation by the eyes. The eyes are clear and brilliant as if moistened. There is no pollution in them, which is why they can see adequately. Seen from this angle, the eye is sufficient to discriminate how dao and de render things brilliant [...].” (Yu 2003: 249).

154 Xinshu, 'Dao de shuo' (8.5/59/16-18). 
indistinguishable breath-air ( $q$ i氣), visual forms or shapes (xing 形), and touchable matter (zhi 質). ${ }^{155}$ The text here makes the watery consistence of the eye explicit, doubtlessly the decisive criterion for choosing the metaphor of the water mirror for eyesight. And just as the water precedes the images reflected on its surface, the eye for Jia Yi has to be there before any form or shape can appear. In order to get a clearer picture of what he considers de to be, it seems helpful to have a look at parts of his respective discussion:

$D e$ (manifestation) is separating from not-being-there (= nothing) and proceeds into beingthere (= something), and therefore it shines, so that it first assumes shape (a body) by contracting (like dried meat) and muddying up. It is for this reason that the six traits appear in it. (...) As for de (manifestation), when it transforms itself, it gets into the position where the traits of things come forth. As long as it has not yet transformed, there is but the brightness of dao (moving/leading along). When dao freezes into ice, it becomes de (manifestation), and the spirit embarks (rides on) de (manifestation). De therefore is the shine of dao (moving/ leading along). Although dao is spirit (i.e., invisible activity), it needs to embark (ride) on de (manifestation), so that (its) appearance has something on which to base itself (...). ${ }^{156}$

155 The Qianzuodu 乾鏊度 (Piercing the Dimensions of Creative Qian) is a Han apocryphal text (wei 緯). Apocrypha were considered practical complements to the classics, often used for prognostication (chen 讖): “Wei is the counterpart of ching which means, literally, the warp or lengthwise threads of a fabric but which is used as the general term for the Chinese classics. Wei thus means the woof or transverse threads of a fabric, but carries the idea of that which completes the classics; the wei supposedly conveyed the other half of canonical truth" (Dull 1966: 6). "[b]orn out of the battle for the throne after the fall of Wang Mang” (p. 234), chen wei texts were considered to be Confucius' secret classics. Their popularity depends on the elevation of the stature of Confucius during the last years of the Former Han (p. 202). Closely interwoven with yin yang-cosmology, these writings were criticized by official scholars since the 1st c. CE and eventually forbidden in the 5th c. CE. The Qianzuodu distinguishes four subsequent stages of the emanation of the world: the absence of anything (taiyi 太易), the presence of qi (taichu太初), the appearance of visible shapes (taishi 太始), and the manifestation of palpable matter (taisu 太素) (Qianzuodu, p. 24). Related accounts are already documented in Huainanzi, 'Chuzhen xun' 1-2 (2/10/14-27). These seem to be the point of reference of speculations on 'being-there', 'not-being there', 'already being-there' etc. transmitted in Zhuangzi, 'Qiwulun’ 齊物論, 8 (2/5/18-20) and 'Zhibeiyou' 知北遊, 8 (22/63/1-3).

156 "Dao leaves emptiness and reaches the confines of reality. This is why it receives brilliance, forming a concentration of internal matter and possessing a shape, this is why the six traits appear. [...] de is produced because of the rise of transformations of (external) things and internal matter. Those transformations are the outward character (qingkuang 情況) of dao. After dao condenses it turns into de, de in turn becomes the abode of spirit. $D e$ is what is projected by the brilliance of $d a o$. And even if dao possesses the attribute of spirituality it definitely makes de its medium, and the fact that is has a form of appearance definitely has its cause, [...]." (Yu 2003: 249-250). 
德者, 離無而之有, 故潤則腒然濁而始形矣, 故六理發焉。 $[. .$.$] 德者, 變及物理之所出$ 也, 未變者道之頌也。道冰而為德, 神載於德。德者, 道之澤也。道雖神必載於德, 而頌 乃有所因, $[\ldots .$.$] 。$

This passage is illuminating in two respects: First, it shows that for Jia Yi, the term de comes close to the notion of solid things. ${ }^{157}$ This is obvious from the formulation of dao's embarking on de which is an almost verbatim repetition from the beginning of the text that simply replaces “wu” (物) 'things' by “ $d e$ ”. At least implicitly, dao is identified with not-being there, while de marks the passage into being-there. This step is described by a metaphor of light: when the brightness of dao contracts and darkens, it appears as the sheen which penetrates, or more literally, "soaks up", things. If the passage is not corrupt, de is compared to dried meat, which would make some sense, as for one thing dried meet is glossy, and as for another, it is marbled with fine veins of fat which resemble the surface of jade. Secondly, Jia Yi chooses the metaphor of freezing water which turns into ice to symbolize the development of dao into de. This specific decision is highly intriguing, as it opens a new perspective on the metaphorics of sight: While in the archeological or textual record of ancient China, there is no evidence which suggests the existence of crystal or glass lenses, ${ }^{158}$ an apocryphal text attributed to prince Liu An of Huainan, the alleged compiler of the Huainanzi, discusses the use of ice lenses to ignite fire. ${ }^{159}$ As we have seen, Jia Yi places the appearance of the eye before the

157 Xu Fuguan claims that de like dao belongs to the "shapeless" (Fan 2019: 170). This is correct insofar as shapes (xing 形) are said to emerge in the last stage of the emanation of concrete things associated with ming 命 (designation). However, this shows that the meaning of xing (shape) is more specific than the one of $w u$ (thing). It does refer not the establishment of things but to their specification which coincides with their designation by a name.

158 Regardless of whether the ancient Chinese knew lenses, the fact that they mainly experimented with bronze mirrors has arguably defined the specific development of Chinese optics: "In China, the alliance of metallurgy and optics served as a foundation for the development of optical media that projected and moved images. Moreover, optical media and their devices relied on an understanding of human vision as mobile and binocular, [...] that describe[s] indigenous Chinese means for constructing pictorial space. Chinese optics thus had very little in common with its "Western" counterpart dominated by transparent lenses (glass and its precursors), monocular vision, and notions of spatial representation linked to the study of geometry and predicated on these phenomena" (Purtle 2018: 88).

159 The relevant passage is transmitted in the fragmentary Huainan Wanbi shu 淮南萬畢術 (Ten Thousand Specialized Techniques of Huainan) (Wu et al. 2015). "Cut ice in a circular shape, hold it into the direction of the sun, place mugwort behind the ice, so that it falls within the shadow, then fire will arise” (削冰令圓, 舉以向日, 以艾承其影則火生, Huainan Wanbi shu, p. 2a. An almost identical formulation is transmitted in Zhang Hua's 張華 (232-300 CE) Bowuzhi 博物志 (Extensive Records on Things, 'The art of jugglery’ 戲術, p. 118: 削冰令圓, 舉以向日, 以艾於後承其影, 則 得火。“They cut ice in a circular shape, hold it into the direction of the sun, and place mugwort behind the ice, so that it falls within the shadow and thus catches fire”, cf. Greatrex 1987: 86; see 
emergence of shaped things. Here we observe that he symbolizes the consolidation of moving dao into constant de by the image of water crystalizing into ice. Even in the absence of evidence for the use of lenses, this intimate interconnection between freezing and the emergence of the eye suggests that Han Chinese scholars might have been aware of the use of lenses to focus light. It is thus imaginable that the water metaphor in connection with the eye invokes not only the image of a water mirror, but possibly also the idea of an ice lens. ${ }^{160}$ Note also, that the Chinese later also decided to use the very word jing, which - among other things - stands for the transparent liquid consisting of sublimated matter which they thought to fill up the eye, for rendering the notion of a transparent crystal lens. Be that as it may: Jia's peculiar conception of the emergence of sight is spectacular, in spite of its admittedly isolated character in early Chinese texts.

As we have observed, Jia Yi describes de as the shine or reflection of dao. That is, he conceives the relationship between dao and de as an exchange of light: To see how he might have imagined the precise connection between the sources of light and the illuminated objects which reflect it back, it is instructive to have a closer look at the passage from the Da Dai Liji mentioned above:

The way of heaven is round, the way of earth is square. The square I call dark. The round I call bright. What is bright is emitting (spitting out) breath-matter ( $q$ i). For this reason it displays (figures of) light outside; what is dark is absorbing (inhaling) breath-matter (qi). For this reason it displays (figures of) light inside. Therefore, fire and the sun display (figures of) light outside, while metal and water display (figures of) light inside. What emits (spits out) breathmatter spreads out, what absorbs (inhales) breath-matter changes. Therefore, the light (yang) spreads out, while the dark (yin) changes. The refined breath-matter of the light (yang) is called 'spirit', the refined breath-matter of the dark (yin) is called 'soul'. 'Spirit' and 'soul' are the root of all kinds of things, the source of rites, music, humaneness and righteousness,

also Laufer 1915: 223). This reference, adduced by Schlegel, was known to Laufer who invoked a philological argument (Zhang Hua's original text was lost in the Song period) to doubt the authenticity of this attribution. Yet, even if the statement is late, and even admitting the fact that the Wanbishu mentioned above, which is attributed to Liu An, has only been preserved in the 10th c. CE Taiping Yulan 太平御覽 (Laufer 1915: 224), Laufer's conclusion that for this reason it cannot predate the seventh century, when burning-lenses first became known in China, still obviously begs the question.

160 However, the freezing of water into ice is also used in a merely metaphorical way by Wang Chong, who compares the process of the condensation of floating 'spirit' into a solid body of a human being to argue against the idea that ghosts are the spirits of dead people: "When water congeals it becomes ice; when breath-matter congeals it becomes a human being; when ice dissolves it becomes water; when a human being dies it turns back to spirit. When we name him or her (= the human being) a spirit, it is just as ice after dissolution changes its name to water.” 水凝為 冰, 氣凝為人; 冰釋為水, 人死復神。其名為神也, 猶冰釋更名水也。Lunheng, 'Lun si' 論死 (62/ 268/14-15). 
and the place from where it arises whether something is good or not, whether it is in order or in chaos. ${ }^{161}$

天道曰圓，地道曰方，方曰幽而圓曰明; 明者吐氣者也，是故外景；幽者含氣者也，是故內 景, 故火日外景, 而金水內景, 吐氣者施而含氣者化, 是以陽施而陰化也。陽之精氣曰神, 陰之精氣曰靈; 神靈者, 品物之本也, 而禮樂仁義之祖也, 而善否治亂所由興作也。 ${ }^{162}$

The 'Tianwen xun' 天文訓 (Instructions on Astronomy) chapter of the Huainanzi presents a shorter version of the crucial passage, though in a different context:

The way of heaven is round. The way of earth is square. The square dominates the dark. The round dominates the bright. What is bright emits (spits out) breath-matter. Therefore, fire is said to display (figures of) light (outside). What is dark absorbs (inhales) breath-matter. Therefore, water is said to display (figures of) light inside. What spits out (emits) breathmatter is spreading, what absorbs (inhales) breath-matter is changing. For this reason, the light (yang) spreads and the dark (yin) changes. ${ }^{163}$

天道曰圓, 地道曰方。方者主幽, 圓者主明。明者, 吐氣者也, 是故火曰外景; 幽者, 含 氣者也, 是故水曰内景。吐氣者施, 含氣者化, 是故陽施陰化。 ${ }^{164}$

These passages are instructive because they define light effects as a function of breath-matter: Brightness is attributed to the emission of $q i$, darkness to its consumption. Light thus is strongest where breath-matter is emitted and it is weak where it is absorbed. The empirical reason for this theory seems to be the fact that bright things like the sun or a fire are reflected elsewhere without there being any reflections of things on them. Likewise, murky things like water or metal reflect other things, notably also bright ones like the sun or a fire. This idea that light is a transfer of matter from one body to another seems to underlie Jia Yi's conception of emerging things as reflections of dao. His postulated transfer of light from emitting dao to receiving de thus arises in the context of the kind of yin and yang "physics" illustrated in the above-quoted Han sources: Note that the alleged direction of movement from dao, the source of light, to de, the target of light, would moreover nicely fit with paronomastic definitions of $d e$ 'virtue' by $d e$ 得 'to receive'

161 For a French translation see Grynpas 1972: 110.

162 Da Dai Liji 大戴禮記, ‘Zengzi Tianyuan’ 曾子天圓, 2 (5.5/35/4-9).

163 Apparently judging from the astronomical context, John S. Major interprets the two terms ying and ming as specifically referring to the light of the sun and the moon respectively: "The Way of Heaven is called the Round; the Way of Earth is called the Square. The square governs the obscure; the circular governs the bright. The bright emits qi, and for this reason fire is the external brilliance of the sun. The obscure sucks in qi, and for this reason, water is the internal luminosity of the moon. Emitted qi endows; retained qi transforms. Thus yang endows and yin transforms.” Major et al. 2010: 115.

164 Huainanzi, ‘Tianwenxun’ 天文訓 2 (3/18/28-30). 


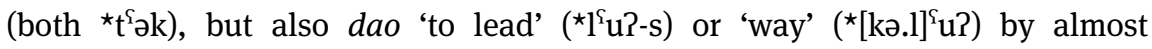
homophonous you 由 'to originate from' ( $\left.{ }^{\star}[\mathrm{u}]\right)$, even if the connection of this link with the light metaphor is unattested elsewhere. ${ }^{165}$

In a next step, Jia Yi relates the contraction of illuminating dao into a condensed mass of reflecting breath-matter to the notion of nature:

As for human nature: When dao and de create things, these things have their shapes (bodies) and the spiritlike (invisible) activity of $d a o$ and $d e$ are concentrated and become one unit of breath-matter, and they will make the clarity of its sheen abundant and rich. At the point in time when it [dao] muddies up and coagulates into something coherent inside a thing, nothing that is to become a thing would generate breath-matter, [breath-matter] all is [simply] gathered (concentrated) inside them, and that's why one calls it human nature. Human nature is the place where the (animating) spirit breath(-matter) comes together. When human nature is established, then spirit breath becomes crystal-clear and penetrates into the outside world, where it is in correspondence with the impulses of external things. ${ }^{166}$

性者, 道德造物, 物有形而道德之神專而為一氣, 明其潤益厚矣。濁而膠相連在物之中, 為物莫生氣, 皆集焉, 故謂之性。性, 神氣之所會也, 性立則神氣曉曉然發而通行於外 矣。與外物之感相應。167

The creation of a single thing according to these lines involves the concentration of a portion of the spirit of dao and de into a singular unit of breath-matter. This lump of matter - we may assume due to the integration of spirit into it - is said to be "soaked" with clarity. The next sentence is not unambiguous, but it makes sense to interpret in a way which views the formation of a thing as not implying the generation of animating breath-matter, but only its concentration inside this thing. It is this aggregation of breath as received from spirit which is identified as the thing's

165 Thus, a Zhouyi quote in the Shuoyuan 說苑 ('Bianwu', 2) not transmitted in the received text of the classic states: “None of the movements of things does not originate from dao.” (物之動莫不由 道 [18.2 / 150/29-151/1]). For a definitory use of these paronomastic links see the definitions in the Han period Sushu 素書 ('Yuanshizhang’ 原始章 [Sushu, pp. 18; 21]). On this particular paronomastic tie see Behr 2011: 26; Boltz/Schemmel 2013: 43-44.

166 "Nature is something created by dao and de. The ten thousand things all have their shapes, while the sublimation (jinghua 精華) of dao and de condenses into one piece of breath-matter (yi qi). Form this we are able to know that dao and de are brilliant and pristine. They sediment, coagulating through the formation of a single body, being altogether inside the ten thousand things, while, again, they exist before the things are born. That animating breath is concentrated in it, is the reason why one calls it nature in the first place. Nature is established by the concentration of spirit and breath. After nature has been established, spirit and breath all manifest themselves in a clear and distinct way, penetrating beyond the bodies of things, in mutual resonance and harmony with the external things." (Yu 2003: 250).

167 Xinshu, 'Dao de shuo' (8.5 / 59/26-60/1). 
nature. The final passage is again highly intriguing: It states that through the establishment of nature the spirit collected in a particular thing not only makes this very thing extremely clear - clarity most probably metaphorically invoking consciousness -, but in fact it holds that the spirit leaves the body when it reacts to impulses received from outward things. Even if this passage certainly is not unambiguous, it clearly suggests that the light encapsulated in a thing at the moment of its production by dao and de emanates or radiates from that thing in order to get into contact with other things. This is a clear indication that seeing was not exclusively conceived as a matter of light immission. Rather, there seems to be an interaction of light coming in from other objects outside and light emitted from inside the body. Unfortunately, the text does not make explicit how it conceives of this "exchange" of light. What it provides is an idea of the alleged relationship between 'human nature' and 'spirit':

(One's?) Spirit is the (animating) spirit breath of dao and de as triggered by one's nature. It is elusive like a spark of fire or a stream of water, and it does not allow to be depicted as a thing (i.e., assimilated to a thing). None among the transformations and changes [of things] are not made by it. The traits of things and the arising of all transformations all are places where spirit changes. $(\ldots)^{168}$

神者, 道德神氣發於性也。康若濼流, 不可物效也, 變化無所不為, 物理及諸變之起, 皆 神之所化也。 169

Spirit thus appears to be the invisible driving force which brings forth both the characteristics of things and their transformations. Jia Yi conceives it as an effect of the animating breath of a thing imbued by dao and de at the time of its creation. Like dao it is itself elusive and is only traceable through its effects - which is no less than the entire path the thing goes through, including all its transformations, that is, the various stages of its development. In this context, it is worth noting that Wang Chong's 1st century CE Lunheng shows that this relationship between 'nature' (xing 性) and 'spirit' (shen 神) is based on an established paronomastic link. ${ }^{170}$ Immediately after invoking the common association of gui 鬼 (MOC kui? / BS *k-Puj?) 'ghost' and gui 歸 'to return' (MOC *kwe / BS ${ }^{\star}[\mathrm{k}]^{\mathrm{w}} \mathrm{j}$ ), he remarks

168 "Spirit results from what dao, de, spirit and breath produce out of nature, its harmonious joy is like the gentle flow of a river, is something which no external thing has a way to imitate. There is no thing which its transformations would not accomplish; both the constant rules of things and their transformations are brought forward by the changing spirit.” (Yu 2003: 251).

169 Xinshu, 'Dao de shuo' (8.5/60/3-4).

170 Murray discussing this link between nature and spirit refers to this very passage from the Xinshu (Murray 2016: 79). 
that “the light breath animates by leading the things, that's why one calls it 'spirit"” (陽氣導物而生, 故謂之神). ${ }^{171}$ Wang thus presents this pun, which connects sheng (MOC * srjen / LHan șen) and shen (MOC *mlin / LHan źin), as reflecting a current view among his contemporaries. The intrinsic relation Jia Yi sees between 'nature' and 'spirit' thus is by no means a peculiarity of his thought.

Clarity is the spirit breath inside, so that it is knowledgeable without there being light. If it is clear then it has an emission (radiation of light) to the outside. Outside and inside interpenetrate into one another, so that (ascertaining) gain and loss, the traits of things (= affairs), and right and wrong all are the task of knowledge. Therefore, I said: The emission (radiation) of light is called clarity. Clarity engenders perceptions, one penetrates them through knowledge. ${ }^{172}$

明者, 神氣在內, 則無光而為知。明則有輝於外矣。外內通一, 則為得失, 事理是非皆職 於知。故曰光輝謂之明。明生識, 通之以知。173

Clarity, that is the term used both for eyesight and for intelligence, is here defined as that portion of spiritual vital force by which dao and de endow a particular thing. If there is no light, this clarity turns into knowledge. Knowledge is thus conceived on the basis of the metaphor of inner light. But it is additionally characterized by its potential to reach out into the external world through radiation. Apparently, it is by way of this emission that it is thought to pervade both the inside and the outside of a thing, thus fulfilling the task of recognizing the outer world. When this clarity shines beyond the thing, it produces the awareness of distinct perceptions, which

171 Lunheng, 'Lunsipian' 論死篇 (62/268/12-14): “Some say: 'ghost' and 'spirit' are the names of dark (yin) and light (yang): The dark (yin) breath-matter returns (gui) by driving things back. That's why it is called 'ghost' (gui); the light (yang) breath-matter animates (sheng 生) by leading things ahead. That's why it is called 'spirit' (shen 神). 'spirit' (shen) means 'to spread' (shen 伸); ['spirit' and 'ghost'] spread (shen 申) and return infinitely; when they arrive at the end, they return to the beginning; humans use the breath of spirit (shen) for living (sheng), and when they die they return (gui) this breath of 'spirit' (shen). The dark and the light are called 'ghost' and 'spirit', and when a human being dies, it is also called 'ghost' and 'spirit'.” (或說: 鬼神、陰陽之名也。陰氣逆物而 歸, 故謂之鬼; 陽氣導物而生, 故謂之神。神者、伸也, 申復無已, 終而復始。人用神氣生, 其死復歸神氣。陰陽稱鬼神, 人死亦稱鬼神。). Cf. Forke 1907: 191-192.

172 "Clarity is only called wisdom when spirit and breath-matter are inside and have no more resplendence. Clarity can also have the outward appearance of radiance. When inside and outside integrate into one single unity, then gain and loss, the dynamics of affairs, and right and wrong are all determined by wisdom. That is why I say 'the mutual illumination of those possessing resplendence is called clarity', 'when clarity produces external marks, they integrate with internal wisdom'." (Yu 2003: 251).

173 Xinshu, 'Dao de shuo' (8.5/60/7-8). 
it pervades through its knowledge. ${ }^{174}$ Again, the description of the processes of consciousness and cognition remain vague. However, there can be no doubt that Jia Yi relegates both the spirit of a thing which is responsible for its growth and development and its exchange with other things outside itself as well as the thing's intellectual capacity, its clarity to one and the same source: Both are taken from the spirit of dao and de. And while the light which communicates with what is outside the thing is still called shen, he conceives ming, clarity, as that part of the "cosmic" spirit which is kept inside: ${ }^{175}$ If the eyes are closed, that is, in the absence of light coming from outside, clarity is knowledge or awareness. It is a consciousness of things which does not depend on their actual presence. However, if the eyes are opened clarity radiates into the outside world - and it seems safe to assume that once it has left the thing, it is thought to turn into the spirit it originally was. At the same time, there also is light (and spirit?) coming in: It seems to be this incoming light which leads to the conscious appearance of discriminate external things. These perceived things are then penetrated and incorporated by knowledge.

One of the few passages on this idea of an interaction between incoming and outgoing spirit can be found in the 'Nei ye' 內業 (Inner Exercises) chapter of the Guanzi 管子 - which is at the same time one of the earliest witnesses for the use of the word xiang 想 in the sense of a mental image or imagination:

When one's body is not well-adjusted (= fixed), de (virtue) does not arrive; if one's inside is not still, then the heart will not be in order. A well-adjusted body absorbs de, the humaneness of Heaven and the righteousness of earth will arrive in abundance. When one's spirit and clarity

174 Texts like the 'Xinshu I' 心術上 chapter (1, 4; 13.1/95/25-26; 96/16-18) of the Guanzi 管子, which explicitly describe cognition in terms of a hierarchical division of labor inspired by the administrative structure of the realm, identify the sense organs as guan 官, 'officials', and the duties they are in charge of as zhi 職 'tasks'. Note that the heart, which occupies the position of the ruler, is not associated with a particular 'task'. Insofar as the sensual organs convey different impressions, they register what is going on outside one's body. Along the lines of this metaphor, only the sensual organs, but not the heart, are in contact with external things. It seems well possible that there exists a paronomastic, if not etymological, relation between $z h i$ 職 ^tək 'registrar' and $z h i$ 識 * $t a k$-s ‘to register'. Interestingly, this etymology would account for both connotations of $z h i$, that is, 'memory' (what has been registered) and 'perception' (what is being registered). The Shuowen Jiezi gives the gloss 'to register details' (ji wei 記微). Accordingly, Duan Yucai 段玉裁 (1735-1815) has identified 職 as the original shape of 識 (Yan/ Zhong 2007: 335).

175 For a discussion on the notion(s) of shen ming, see Knoblock 1988: 252-255. In spite of the difficulties of the Xinshu, it is clear that the text presents a rationalization of these terms. For this reason, I consider it justified to ignore more ancient, explicitly religious interpretations. 
attain the outmost degree, they shine in ${ }^{176}$ the knowledge of the ten thousand things. Inside, righteousness ${ }^{177}$ is maintained, and there is no wavering (doubts). One does not interfere the sense organs with things, nor does one interfere the heart with the senses. It is on this that I say the inside is kept (in order). There is spirit which is in one's body by itself. Once it goes ahead, once it comes back. No one is able to track it in thinking. But losing it, one certainly falls into chaos, while keeping it, one certainly is in order. If one respectfully dismisses it (= spirit) from its abode, essence will come in by itself. ${ }^{178}$ Refined as it is, its imagination tracks it (= spirit?) in thought; still as it is, its memory keeps it (= spirit?) in order. ${ }^{179}$ Through one's earnest expression of anxiety and respect, essence will reach a point of fixation. If one keeps it (= spirit) without letting it depart, the ears and eyes will not disperse (it), and the heart will have no other plans (patterns). If there is a well-adjusted heart inside oneself, the ten thousand things receive their measurements.

形不正, 德不來。中不靜, 心不治。正形攝德, 天仁地義, ${ }^{180}$ 則淫然而自至。神明 ${ }^{181}$ 之極, 照 乎知萬物。中義守不忒, 不以物亂官, 不以官亂心, 是謂中得。有神自在身, 一往一來, 莫之 能思。失之必亂, 得之必治。敬除其舍, 精將自來。精想思之, 寧念治之。嚴容畏敬, 精將至 定。得之而勿捨,耳目不淫, 心無他圖。正心在中, 萬物得度。182

The sentences immediately preceding this passage make it clear that the 'exercises' of concentration in the Guanzi are designed for the ruler. Even if it is unclear what is meant by 'well-adjusted' (zheng 正), the ensuing characterization of one's internal constitution as 'still' or 'tranquil' (jing 靜) suggests that the word refers to stability in the sense of a fixed position as well - be it literally, in the sense of rest or motionlessness, or in metaphorical terms, referring to one's hierarchical status. In the present context, however, we are less concerned with the question what kind of

176 Rickett has "The ultimate accomplishment of the Spirit - How brilliant! It knows all things, [...]." He considers shen ming a binome and renders it by capitalized 'Spirit'. The phrase zhao hu he identifies as an exclamation belonging to the previous sentence. I consider both decisions problematic. (Rickett 1965: 161).

177 Rickett (1965: 161) follows Sun Yirang's emendation of this yi. In my view, our discussion shows just how essential this term is for understanding the larger implications of the passage.

178 Rickett translates: "Respectfully keep clean its abode. And (thus the embodiment of) the essence will then come of itself.” (p. 162).

179 Rickett reads this as an instruction rather than an explanation: "Quiet your thoughts in order to contemplate it.” (p. 162). By leaving away jing 精 and contracting xiang si 相思 into an indistinct 'to contemplate', this translation obliterates crucial terminological distinctions and moreover blurs the references to the previous topic of 'tracking spirit in one's thinking' (si zhi 思之).

180 Harold Roth (1999: 222) considers these four characters to be a later Confucian interpolation. In view of our discussion this appears hardly plausible. Cf. Graziani 2011: 11, n. 11.

181 Graziani 2011: 11, n. 19 follows Jeffrey K. Riegel, who emends ming into mo 莫, which yields the four character phrase 神莫知極 (“Spirit - no one knows its limit”) which is also attested in the 'Xinshu xia' 心術下 (Techniques of the Heart II) chapter of the Guanzi. If our interpretation is right, there is obviously no need for this emendation.

182 Guanzi, 'Neiye' (16.1/116/11-13). 
'meditation' the Guanzi invokes, but rather how it explains the mental clarity, the well-ordered 'heart', supposedly resulting from one's exercise of concentration. The imagery of the Guanzi compares the body to a container. More interesting than this is how the text characterizes what is supposed to fill it up: The first term which appears is de, commonly rendered 'virtue', an abstract moral term which can only be "stored" in a metaphorical sense. However, in the light of Jia Yi's material conception of $d e$ as a brilliant, but still unshaped and colorless congelation of $q i$, there is quite a concrete sense in which one's body can be imagined to ingest $d e$. The passage further continues by describing the process which leads to this concentration of de: It is said to result from the spontaneous arrival of what is called the "humaneness of Heaven" (tian ren 天仁) and the "righteousness of earth” (di yi 地義). At the first glance, this again seems to be yet another instance of figurative speech. But this might be a misleading impression, a premature conclusion based on our reading the terms ren ('humaneness') and $y i$ ('righteousness') in the abstract and exclusively moral sense which they later assumed. That there is a material or organic aspect to these notions is suggested by the fact that the expressions "humaneness of Heaven" and "righteousness of earth" are resumed, in the ensuing phrase, by the two terms shen 'spirit' and ming 'clarity' - whose perfection is then invoked for specifying the state of a "well-ordered" heart which the exercise aims to attain. For a better understanding of this vocabulary it is worth recalling what we have observed so far: First, the above-discussed passages from the Da Dai Liji and the Huainanzi present light as the movement of animate spirit breath from Heaven to earth. More specifically, they conceive it as something filling the space between different bodies who are distinguished as to whether they emit light or absorb it - the latter referring to things that merely reflect rather than radiate. Second, Jia Yi's text on dao and de draws a line between 'spirit' as the light filling the space outside the solid bodies be it free-floating or body-bound -, and 'clarity' as that part of spirit which is encapsulated in solid bodies and 'illuminates' them from within. Finally, the Guanzi passage under discussion speaks of an abundance or effluence of 'humaneness' and 'righteousness' coming from Heaven and earth respectively. Note, that what is rendered "abundance" (yin 淫) here corresponds to the same word which recurs, a few lines later, in the negative connotation of 'dispersing', now referring to the uncontrolled loss of 'spirit' through the sensual organs. There is thus good reason to assume that the Guanzi also refers to 'spirit' when it speaks about the spontaneous arrival of Heaven's 'humaneness' and earth's 'righteousness': Possibly, these two phrases respectively refer to 'spirit' as the light emitted from heaven, and 'clarity' as the light absorbed in earth, that is, contained in solid bodies that reflect. And maybe jing, 'essence' or 'refined stuff', refers precisely to the purest kind of reflecting substance. As for the terms 'humaneness' and 
'righteousness', it is important to keep in mind, that the Guanzi addresses here meditation in the larger context of rulership. And in this regard, it is worth noting that the Chunqiu Fanlu 春秋繁露 (The Luxuriant Dew of the Spring and Autumn Annals), a second century BCE text commonly attributed to Dong Zhongshu 董仲舒 (2nd c. BCE), attempts to base the entirety of human relations on a net of interactions between the binary poles of 'humaneness' and 'righteousness'. Drawing on paronomastic ties, 'humaneness', ren ( ${ }^{\star}$ nin), is identified as a means to content 'others' (ren人 ${ }^{\star} \mathrm{ni}[\mathrm{n}]$ ), and 'righteousness', yi ( $\left.{ }^{\star} \mathrm{n}(\mathrm{r}) \mathrm{aj}-\mathrm{s}\right)$, is defined as 'adjusting' (zheng 正) the 'I' (wo 我 * ${ }^{\text {` }}$ aj?). The former is moreover said to focus on the far, while the latter is associated with the nearby ${ }^{183}$. Eventually, the difference between the two is reduced to the directedness of their attribution: humaneness is specified as 'outgoing' (wang 往) - the assertion of 'humaneness' proceeds from oneself to others. 'Righteousness' is characterized as 'incoming' (lai 來) - the assertion of 'righteousness' proceeds from others to the self. This reduction results in a semantic approximation of the terms ren and yi to an "outgoing” and "incoming” movement and thus would render them into adequate characterizations of the motion of light with respect to bodies either "emitting" or "absorbing" it. Or put differently: ren and yi in this sense indeed seem to qualify for capturing the movement of 'spirit' with respect to radiating and reflecting entities respectively. And while Heaven and earth are not even mentioned in the Chunqiu Fanlu, a few observations still allow us to connect its definitions to the above

183 Chunqiu Fanlu, 'Renyi fa' 仁義法: “[...] What the 'Spring and Autumn' regulates is the relation between other humans and the 'I'. That by which it regulates the relation between other humans and the 'I', are humaneness and righteousness. By humaneness one calms other humans, by righteousness one adjusts the 'I'. Therefore, 'humaneness' is to say "other humans”, 'righteousness' is to say “I”. Just say the names, and they are already set apart! 《春 秋》之所治, 人與我也。所以治人與我者, 仁與義也。以仁安人, 以義正我, 故仁之為言人 也, 義之為言我也, 言名以別矣。(8.3/38/17-18; cf. Queen/Major 2016: 313). 'Saying the name' in the Chunqiu Fanlu is a technical term referring to paronomastic definitions: Listening how these terms sound, one hears immediately that 'humaneness' ( ${ }^{\star}$ nin) belongs to 'other humans' $\left({ }^{\star} n i[n]\right)$ and 'righteousness' ( $\left.{ }^{\star} \eta(r) a j-s\right)$ belongs to the 'I' ( ${ }^{\star} \eta{ }^{\complement}$ aj?). "Therefore, the 'Spring and Autumn' has designed a model for humaneness and righteousness. The model of humaneness consists in loving other humans, not in in loving the 'I'. The model of righteousness consists in correcting (adjusting) the 'I', not in correcting others.” 是故《春秋》為仁義法。仁之法在愛人, 不在愛我。義之法在 正我, 不在正人。(8.3/38/20-21; cf. Queen/Major 2016: 313) “Asserting righteousness and humaneness are each distinct (shu): Calling someone humane, (the I) advances (to other humans); calling someone righteous, (other humans) come (to the ' $I$ '). Humaneness focuses on the distant. Righteousness focuses on the near. If his sense of love reaches other humans, call him humane; if his sense of <appropriateness> ( ${ }^{\star} \mathrm{n}(\mathrm{r})$ aj) ( ${ }^{\star}$ righteousness) reaches the 'I', call him righteous. Humaneness is dominant with respect to other humans; righteousness is dominant with respect to the 'I'.” 是義與仁殊。仁謂往, 義謂來, 仁大遠, 義大近。愛在人謂之仁, 〈宜〉(“義)在我謂之 義。仁主人, 義主我也。(8.3/39/13-14; Cf. Queen/Major 2016: 316). 
passage from the Guanzi: First, in the passage under discussion, the Guanzi alerts one to 'adjust' (zheng) one's body. And as we have seen, the term 'adjustment' is precisely what 'righteousness' according to the Chunqiu Fanlu recommends us to engage in with respect to the 'I' - and given the dominant physical understanding of the 'I' as one body among others, it seems unproblematic to identify this 'I' with the body, that is, the container the Guanzi stages as the object of cultivation. Second, the Guanzi itself further qualifies the state of bodily perfection by the maintenance of righteousness inside, an inner state which is said to result into the dissolution of doubts. Thus, in view of our previous discussion suggesting that shen is the light which Heaven abundantly sends down to earth, the qualification of such selfless generosity attributed to Heaven as 'humane' seems entirely traceable, all the more if one considers the degree of generality this concept was accorded in the Chunqiu Fanlu passage discussed above. Likewise considering that we have proposed that ming refers to the light which is continuously encapsulated in solid bodies and shining through their surface, it is also understandable to capture such "absorbed" light by the term "righteousness", especially if we take into account that we have identified ming as what enables our right knowledge of things - and it is precisely this which in the Guanzi allows the sage to dispel his doubts. Third: a few lines further down, the Guanzi passage itself speaks about one's 'spirit' sometimes leaving one's self and sometimes coming back. Here, it uses precisely the two verbs wang and lai associated, in the Chunqiu Fanlu, with 'humaneness' and 'righteousness', respectively. In view of these connections, I assume that the categories of humaneness and righteousness in the Guanzi metaphorically identify our two modes of spirit through their respective sources and their inherent movement - expansion onto others, retraction into oneself: Shen is an unceasing flow of light from Heaven to all solid beings including our own body; ming is our inner light which infallibly distinguishes right and wrong. At the end of this difficult and largely implicit passage, the Guanzi eventually identifies knowledge ( $z h i$ 知) of external things as something manifest in the intermingled light (zhao 照) of 'spirit' and 'clarity', an assessment similar to Jia Yi's explanation of cognition as a combination of 'knowledge' ( $z h i$ 知) and 'perception' (shi/zhi ${ }^{184}$ 識). The Guanzi suggests that reaching the highest degree of this twofold illumination enables one to know the entire range of external things, but it presupposes one's success in preventing his organs of sense and thought from transgressing their respective duties. More interesting, but less clear, is what the Guanzi states next: Like Jia Yi's 'Dao de shuo', the text claims that our body contains some amount of spirit in and by itself - arguably infused by Heaven and earth at the moment of our creation. However, this spirit is said to circulate, leaving

184 Cf. n. 174, p. 50 above. 
and entering the body back and forth. Moreover it is claimed that no person is able to track its course - which is fatal because its loss amounts to chaos, while we can maintain our inner peace by keeping it. The text then changes its focus from spirit to essence (jing): while humans are said to be too coarse to observe spirit, this purified matter is characterized as capable to track spirit in imagination and to arrange it in memory. At this point the Guanzi thus invokes an idea familiar to us from our previous discussion of Wang Chong: The formation of imaginations is attributed to essence. In addition to what we know from Wang, the Guanzi specifies that the images taking shape in our essence are following the movement of the spirit leaving the body. Even if it does not specify what exactly essence and spirit are supposed to be, the Guanzi agrees with Jia Yi in drawing a clear-cut distinction between the two. The concrete interaction is imagined as a kind of changing of the guard: Respectfully dismissing spirit allegedly results in the spontaneous arrival of essence supposed to track it. Note the similarity between this idea of an agent tracking the movement of the spirit delegated outside one's body and the meaning of registrar, zhi 職, arguably connoted or at least paronomastically invoked in the term shi/zhi 識 for 'perception'. Interestingly, essence in a next step is related to one's earnest countenance - and in view of our previous discussion we may infer that this refers to the expression of one's eyes. The fixation of our view in anxiety and respect is supposed to keep essence from floating away. Apparently, it is through a concentrated look of our eyes that we are supposed to be able to focus on the pattern of the specific things we wish to track. When we look around we run the danger that our spirit leaves without our essence being able to follow it. While it is difficult to assess how exactly this interaction of a moving shen and a tracking jing is to be related with the imagery of reflection of incoming and outgoing light as developed by Jia Yi, two things are still clear. First, the Guanzi passage confirms our finding that spirit, clarity and knowledge are conceived in terms of light and reflection. Second, the refined matter making up the eye also is key in the conception of vision in the Guanzi. Like Jia Yi, the text distinguishes essence from spirit: Unlike spirit it is coarse enough for us to get a grip on it. Like this, it acts as a mediator between the body and its organs on the one hand, and the subtle and imperceptible spirit on the other. It is imagined as the most sublime kind of matter - too pure to be singled out by form or color, but still perceptible through its shine. Yet, through its cohesiveness it must have a spatial extension and - unlike freely floating spirit - it must be able to fill up or "stuff" spaces left free by the cavities inside the body. Combining our observations from the Guanzi and the Xinshu, it seems plausible to assume that this essence was imagined as ming, that is, as containing spirit, which after all made it shine, and that it was thought to be capable of setting some of this spirit free - all by tracking its light through reflection. Even if our interpretation of these observations stretches the 
conclusions to the limits of what the scarce sources at our disposal warrant, our discussion has made it clear that these texts draw on an entire imagery of light and spirituality which we still hardly understand.

Summarizing our discussion on Jia Yi's 'Dao de shuo', it is obvious, that both its peculiarities and difficulties remain intriguing - in spite of the intertextual references presented in this paper. At the same time, our contextualization of some of its central ideas shows that Jia draws from conceptions about the relationship between different bodies that conceive light as a transfer of breath-matter from one thing to another. In this process, the sources of light are identified as providing $q i$, while bodies which reflect this light are considered as consumers of qi. In Jia Yi's cosmology, the appearance of things thus reflects a translation of breath-matter from an illuminating source into reflecting targets. As we have seen, this conception of the relationship between dao and de seems to reflect views current at his time. What is peculiar about his text is that Jia goes on to further derive the notions of nature, spirit, clarity and designation from the light of dao. Notably, he aligns dao, spirit and clarity by identifying all of them with the expansion of light: dao is its source; spirit is its movement; clarity is spirit as encapsulated inside the body of an individual thing. Jia Yi thus presents an entire cosmology and gnoseology of light, which in spite of many parallels to contemporaneous sources seem quite exceptional in a Han Chinese context.

\section{V}

The three texts discussed in the second through fourth parts of this paper are vastly different and were composed over a timespan reaching from the early Western Han period to the beginning of the medieval period in the late 3rd century CE. Jia Yi's text presents its cosmology of light in a metaphorical account on personal cultivation. Therefore, our interpretation is difficult not only because of its peculiar terminology, but also because it is unclear to what extent the text is to be read in an allegorical rather than literal sense. Sima Biao's depiction of vision is an isolated comment and therefore its interpretation not least hinges on our attempts to contextualize it. Wang Chong's discussions on the role of 'spirit' in imagination certainly are not intended as a systematic account on the topic. However, the parallels in texts like the Guanzi show that his views can still be considered representative to some extent. Finally, while the fact that our investigations cover several texts of a varying degree of explicitness and consistency clearly limits the bearing of our conclusions, our study still provides fresh insights into the key concepts discussed. Taking into account all these difficulties, our textual witnesses clearly bespeak a shared understanding of the nature and 
function of 'spirit' and highlight its close relation to vision and seeing, a connection with a highly plausible relevance pointing beyond the immediate context of the three particular texts discussed. 'Spirit' is consistently associated with the essence, the most rarefied form of matter, which circulates in the body and gathers in the heart, the center of thought and emotion, and condenses in the eye. Texts compare its translucid and liquid consistency to water - and they emphasize its mirrorlike ability to translate incoming light into the shapes of the things that emit it. And while the precise relationship between essence and spirit is left implicit, it seems as if the former refers to the material basis of reflection while the latter stands for the movement itself of the light emitted and reflected. Importantly for our context, there is a distinction between a notion of particularized spirit as encapsulated in individual things on the one hand, and of a universal spirit imagined as the general driving force of dao which moves and transforms things. And notably, the former is conceived as the force that imbues particular things with life and consequently is associated with the concept of xing, 'nature'. Eventually, the ability of the eye, the most compacted mass of essence in the human body, to see, its clarity or perspicacity, is more specifically identified as a part of that share of universal 'spirit' which is ingrained into a human body at the very point of its formation. In other words, the water- or mirror-like quality of the eye which allows it to reflect is due to its essential identity - through participation - with 'spirit'. Like the animating driving force of a living being it is only distinguished from universal spirit through its location in a particular thing and its fulfilment of a specific function which separates it from the remaining undifferentiated and floating spirit that fills the world - or is enclosed in other things. Thus, the eye is not only considered as the highest concentration of spirit in the human body, but spirit is moreover identified with the animating vigor and vitality of living beings.

If now we conclude our paper by returning to our initial discussion of early reflections on painting, it becomes entirely traceable why Gu Kaizhi considers the depiction of the eye key for maintaining the liveliness of the portrayed person. Even if the eye may not be the "seat", let alone the "source" of "the" human "soul", it marks the focus point where an individual's spirit, his or her life-giving force, gathers and steps into interaction with other beings. Our discussion has also shown that the notion of 'spirit' is intrinsically related to light, reflection, and vision. Accordingly, it comes without much surprise that it occurs in the context of the visualization of spiritual pilgrimages to transcendent figures in imaginary landscapes in Early Medieval texts. More specifically, we note a continuity and - in fact, an underlying identity - between the individual spirit as encapsulated in the human body and the universal spirit as the all-encompassing driving force of the cosmos. The distinction between what Cai Zong-qi calls "xing-bound" and 
"xing-free" spirit thus is nothing essential that would eternally distinguish the two - such as a human soul as against God - but it only marks a provisional boundary between the "portion" of 'spirit' concentrated in a particular thing in contrast to that part of 'spirit' which floats freely among things. Leaving the confines of painting and art production, this incidentally also shows the fundamental flaw of unspecified translations of shen as "soul". Of course, this admittedly is not a trivial question: Not least due to the lack of grammatical number in Chinese it is difficult to decide, in each particular instance, if a word like shen (our 'spirit') is conceived in an individualized manner - like spirits or souls in the plural - or rather as a uniform mass of spirit stuff. And although this question clearly frustrates any attempts at finding a general answer, Jia Yi's description of the establishment of an individual's nature by infusing a particular entity with 'spirit' clearly speaks in support of the second possibility: The spirit which forms the individual's nature (xing 性) is simply taken from the overall mass of shen. And when this body dissolves, the spirit encapsulated therein disperses and reunites with the undifferentiated mass of spirit from which it had been extracted.

If we now try to step back and to relate our insights on traditional views on spirit to early texts about landscape painting, there also seems to be some degree of continuity. For example, Jia Yi's text seems to render more palpable the enigmatic opening lines of Zong Bing's preface on painting mountains and waters: When we relate Zong's characterization of the sage as "inhaling the dao and reflecting the things” (han dao er ying wu 含道而映物) to Jia's “cosmology of light”, this seems to invoke the mirrorlike capacity of a sage to absorb the light he receives from an illuminating body and to translate it into an accurate reflection of the former, all by remaining himself unaffected and untainted. It would thus stand for a kind of "non-distortive" receptivity characteristic for materials like water, metal, or jade, as well as for exceptionally clear-sighted humans who deserve the attribute of being de, "virtuous": Note that, in his defense of the imperishability of 'spirit', transmitted in the apologetic Mingfolun, Zong explicitly invokes the mirrormetaphor to characterize shen. ${ }^{185}$ Zong's description of the worthy (xian 賢) is more difficult, but when he says that this less perfect person "settles his troubled bosom and savors the shapes (of things)" this can be easily related to the same imagery: Consider that the character chang 暢 (MOC *thraph / LHan $\underline{t}^{\mathrm{h}_{\mathrm{ian}}}{ }^{\mathrm{C}}$ ) which occurs in Zong Bing's phrase chang shen, and which is usually translated as something like “setting free one's spirit”, is used, in the Shiming 䆁名 (Explaining Terms), as a definition of digestion which is said to dissolve dregs and floating particles, ${ }^{186}$

185 Park 2012: 212-213.

186 Shiming, ‘Shi xingti’ 釋形體 (2.2/21/17): “The bowels are purifying. Pervaded by the purifying breath-matter of the stomach, they remove dregs and dirt.”腸, 暢也。通暢胃氣, 去㳯檅也。 
while the Western Han Chunqiu Fanlu uses the character as a loan for 毘 'black millet wine' (MOC *thraph / LHan $t^{h}$ ian $^{\mathrm{C}}$ ), apparently alluding to the clarity of this beverage purified from pomace and turbid particles. The Chunqiu Fanlu passage under consideration belongs to a chapter on adequate gifts for different ranks of aristocracy - and it traces the adequacy of these presents back to their defining characteristics which it metaphorically links with the degree of moral perfection associated with the respective rank: Notably, it deems 'clear wine' with its attributes of purity the gift adequate for a 'sage' (shengren 聖人) - and it contrasts this with jade, obviously considered of a somewhat lower degree of purity, which is appropriate for the gentleman (junzi). ${ }^{187}$ In spite of the centuries separating these Han period works from Zong, it is notable that the latter, too, starts his text with a distinction of different stages of perfection, contrasting the sage and the worthy (rather than the gentleman). ${ }^{188}$ In view of the metaphorics of purification at play in this discourse of moral perfection, it thus seems even plausible that the expression chang shen in Zong Bing's text refers to intentional attempts to at least approximate the clarity of the sage. Given the weight of the notion of 'spirit' in Zong's preface, and in view of the intimate relation of this term to light and visuality, it further seems probable that the aim of his indulgence in landscape painting is the clarification rather than liberation of the spirit, a practice which is intended at enhancing the receptivity of light - even with the aim of ultimately achieving enlightenment, that is, turning into a sage. Our discussion of sight and visuality in pre-Buddhist China thus opens new perspectives on Zong's text, despite the temporal distance setting apart his reflections on landscape painting and Jia Yi's speculative text on dao and de. But still, if Nakamura Shigeo 中村茂夫 (1913-1990) is right in suggesting that Zong's sage is no one less than the Buddha himself who

187 Chunqiu Fanlu, 'Zhi zhi’ 執䞇: “Black millet wine has [qualities] that are the same in kind as the sage, who is pure, humane, pellucid, and unadulterated and who possesses the highest kind of knowledge. What [the sage] contains within himself is inexhaustible in its virtue and accord; What [the sage] exhibits in his actions is inexhaustible in its magnanimity and fructification. Its refined aroma, pleasant and fragrant, penetrates up to Heaven.... it is ... without anything to pick out, is as one with [the qualities of] the sage. (Queen/Major 2016: 537); (暢有似於聖人者, 純仁淳粹, 而 有知之貴也, 擇於身者盡為德音, 發於事者盡為潤澤。積美陽芬香, 以通之天。合之為一, 而 達其臭, 氣暢於天。其淳粹無擇, 與聖人一也。[16.1/71/25-28]).

188 The Chunqiu Fanlu identifies the sage with the son of heaven. We may surmise that from the perspective of Zong Bing who identifies the sage with the Buddha, this referent who is, after all, a real human being, clearly represents a lower degree of purification. In view of this, the redirection of the sedimenation and clarification metaphor for the purification of spirit to the lower stage of the worthy, whom Zong characterizes as "clearing his bosom and indulging in (the) images (of things)” (cheng huai wei xiang 澄懷味像), would seem entirely consistent. This chimes nicely with Nakamura Shigeo's identification of Zong's sages as Buddhas and his worthies with bodhisattvas (cf. Bush 1983: 134). 
enlightens the sentient beings while his worthy represents the bodhisattva, ${ }^{189}$ his emphasis on the role of spirit would make perfect sense. As we have seen in our discussion of Jia Yi's text, the very notion of spirit is related to an entire imagery of light, notably the idea of its passage from radiating dao to reflecting de. Insofar as they are different terms for the ultimate source of light, the Buddha and dao thus seem to coincide. Zong's reference to the notion of spirit thus seems to imply a sustained emphasis on light. This in turn entails an importance of visuality which helps understand why the very notion of spirit may have been considered so relevant to the essentially visual art of painting, an aspect that has possibly been overlooked so far.

I wish to conclude this paper with a proposal regarding the specific Buddhist contributions to landscape painting, shortly touched upon at the beginning of this paper. In view of our discussion of the intimate relation between 'spirit' and visuality in ancient China, it appears as if, at least in the early period during the Northern and Southern dynasties, possible allusions to Buddhist notions of omnipotence (abhijñ̄a) and concentration (samādhi) are secondary and essentially hinge on the common rendering of the former term in Chinese as shen tong, that is "spiritual pervasion". Arguably, it is thus closely interconnected with a notion of shen as an essentially de-individualized and all-encompassing medium of the movement of light and consciousness vouchsafing the continuity and mutual connection of its various parts which are scattered into locally and temporally distinct entities. Inherited by early Buddhists to capture, among other things, the idea of karmic retribution (yebao 業報), this notion dogmatically stands on brittle ground as it potentially undermines the central doctrine of anätman - the claim that there is no persistent individual self or soul. It is observable that Chinese Buddhists already in the 4th century became aware of this difficulty and contrasted shen, which they now associated with Daoism, to their own notion of 'consciousness' or 'knowledge' ( $z$ hi 知 $)^{190}$. According to Sengrui 僧睿 (371-438), it is the merit of his teacher Kumārajīva (343-413), who consistently rendered Sanskrit atman as shen, that this term with its potentially essentialist underpinnings was eventually discarded by Buddhists. ${ }^{191}$ Against this backdrop, the specific contribution of Buddhism to Chinese theories of the arts thus rather seems to consist in the establishment, since the beginning of the Eastern Jin period, of a

189 Nakamura Shigeo has suggested that "the distinction made between the sages and virtous men reflects the separation between Buddhas, whose minds are identified with the universe, and bodhisattvas, who still perceive the world in terms of a dichotomy between subjective and objective” (Bush 1983: 134)

190 Krause shows this on the example of Xuanchang's 玄暢 (fl. 445) largely fictitious biography of Harivarman (Krause 2003: 127).

191 Park 2012: 194-195. 
discourse of imagination and visualization. Its importance would not so much be the transfer of particular ideas about visuality or techniques of painting but rather the fact that it provided the general discursive framework which, first and foremost, opened the way toward critical discussions of the role of visuality in the art of painting.

\section{References}

\section{Primary Sources}

Bowuzhi 博物志 = Zhang Hua 張華: Bowuzhi xin yi 博物志新譯. Transl. and ed. by Zhu Hongjie 祝鴻傑. Shanghai: Shanghai Daxue Chubanshe, 2010.

Chunqiu Fanlu = Liu Dianjue 劉殿爵 (D.C. Lau) / Chen Fangzheng 陳方正 (eds.) (1994): Chunqiu Fanlu zhuzi suoyin 春秋繁露逐字索引 [A Concordance to the Chunqiufanlu]. Hong Kong: Xianggang Shangwu Yinshuguan.

Da Dai Liji = Liu Dianjue 劉殿爵 (D.C. Lau) / Chen Fangzheng 陳方正 (eds.) (1992): Da Dai Liji zhuzi suoyin 大戴禮記逐字索引 [A Concordance to the Dadai liji]. Taibei: Taiwan Shangwu Yinshuguan.

Dafangdeng dajïing 大方等大集經 (Mahāvaipulyamahāsamghātasūtra), trans. Dharmakșema (Tanwuchen 車無讖, 385-433) = Taishō Tripițaka, Taishō Shinshū Daizōkyō 大正新修大藏經, vol. 13, no. 397. Edited by Takakusu Junichirō 高楠順次郎 / Watanabe Kaigyoku 渡邊海旭. Tōkyō 東京: Taishō Issaikyō Kankōkai 大正一切經刊行會, 1924-1932.

Dazhi du lun 大智度論 (Mahāprajñāpāramitāśāstra), Nāgārjuna (Longshu 龍樹), trans. Kumārajīva (Jiumoluoshi 鳩摩羅什, 343-413) = Taishō Tripițaka, Taishō Shinshū Daizōkyō 大正新修大藏經, vol. 25, no. 1509.

Forke, Alfred (transl. and annot.) (1907): Lun-hêng. Part l. Philosophical Essays of Wang Ch'ung. Leipzig: Otto Harrassowitz; London: Luzac \& Co; Shanghai: Kelly \& Walsh Limited.

Forke, Alfred (transl. and annot.) (1962 [1911]): Lun-hêng. Part II. Miscellaneous Essays of Wang Ch'ung. Second edition. New York: Paragon Book Gallery.

Foshuo fangdeng bore nihuan jing 佛說方等般泥洹經 (Caturdārakasamādhisūtra), trans. Dharmarakṣa (Zhu Fahu 笈法護, 229-306) = Taishō Tripițaka, Taishō Shinshū Daizōkyō 大正新修大藏經, vol. 12, no. 378.

Foshuo Xuzhen tianzi jing 佛說須真天子經 (Suvikrāntacintādevaputrapariprcchā), trans. Dharmarakṣa (Zhu Fahu 竺法護, 229-306) = Taishō Tripițaka, Taishō Shinshū Daizōkyō 大正新修大藏經, vol. 15, no. 588 .

Graziani, Romain (trad.) (2011): Écrits de Maître Guan - Les Quatre traités de l'Art de l'esprit. Paris: Les Belles Lettres.

Greatrex, Roger (transl. and ann.) (1987): The Bowu Zhi - An Annotated Translation (Skrifter utgivna av Föreningen för Orientalska Studier; 20). Stockholm: Institutionen för Orientaliska Språk.

Grynpas, Benedykt (1972): Les Ecrits de Tai l'Ancient et le calendrier des Hia - textes confucéens taoïsants (Librairie d’Amérique et de l’Orient Adrien Maisonneuve. Paris: J. Maisonneuve. 
Guangchuan huaba 廣川畫跋 = Dong You 董备, Guangchuan huaba 廣川畫跋. In: Wenyuange siku quanshu 文淵閣四庫全書, vol. 813, pp. 443-501. Taibei: Taiwan Shangwu Yinshuguan, 2013.

Guanzi = Liu Dianjue 劉殿爵 (D.C. Lau) / Chen Fangzheng 陳方正 (eds.) (2001): Guanzi zhuzi suoyin 管子逐字索引 [A Concordance to the Guanzi]. Taibei: Taiwan Shangwu Yinshuguan.

Guoyu = Liu Dianjue 劉殿爵 (D.C. Lau) / Chen Fangzheng 陳方正 (eds.) (1999): Guoyu zhuzi suoyin 國語逐字索引 [A Concordance to the Guoyu]. Taibei: Taiwan Shangwu Yinshuguan.

Han Feizi = Liu Dianjue 劉殿爵 (D.C. Lau) / Chen Fangzheng 陳方正 (eds.) (2000): Han Feizi zhuzi suoyin 韓非子逐字索引 [A Concordance to the Hanfeizi]. Taibei: Taiwan Shangwu Yinshuguan.

Hanshi waizhuan = Liu Dianjue 劉殿爵 (D.C. Lau) / Chen Fangzheng 陳方正 (eds.) (1992): Hanshi waizhuan zhuzi suoyin 韓詩外傳逐字索引 [A Concordance to the Hanshi waizhuan]. Taibei: Taiwan Shangwu Yinshuguan.

Hanshu = Ban Gu 班固; Wang Xianqian 王先謙 (ed.) (1962): Hanshu buzhu 漢書補注. Beijing: Zhonghua Shuju.

Hongmingji 弘明集, comp. Sengyou 僧祐 (445-518) = Taishō Tripițaka, Taishō Shinshū Daizōkyō 大正新修大藏經, vol. 52, no. 2102.

Huainan Wanbi shu 淮南萬畢術 = Liu An 劉安. Huainan wanbi shu. In: Shizhong gu yishu 十種古 遺書; 5. (Baibu congshu 百部叢書; 57). Taibei: Yiwen Yinshu Guan 藝文印書館, s.a.

Huainanzi = Liu Dianjue 劉殿爵 (D.C. Lau) / Chen Fangzheng 陳方正 (eds.) (1992): Huainanzi zhuzi suoyin 淮南子逐字索引 [A Concordance to the Huainanzi]. Taibei: Taiwan Shangwu Yinshuguan.

Huainanzi jiaoshi = Zhang Shuangdi 張雙棣 (1997): Huainanzi jiaoshi 淮南子校釋. Beijing: Beijing Daxue Chubanshe.

Jingdian shiwen = Lu Deming 陸德明. Jingdian shiwen 經典釋文. 3 vols. Shanghai: Shanghai Guji Chubanshe, 1985.

Kalinowski, Marc (trad.) (2011): Wang Chong, Balance des discours: destin, providence et divination $=$ Lunheng. Paris: Les Belles Lettres.

Knoblock, John (ed. and transl.) (1988): Xunzi: A Translation and Study of the Complete Works, vol. 1. Stanford: Stanford University Press.

Knoblock, John / Riegel, Jeffrey (ed. and transl.) (2000): The Annals of Lü Buwei. A Complete Translation and Study. Stanford: Stanford University Press.

Lamotte, Etienne (transl.): The Treatise on the Great Virtue of Wisdom of Nāgārjuna (Mahāprajñāpāramitāśāstra), Volume V, Chapters XLIX - LII and Chapter XX (2nd series), Composed by Bodhisattva Nāgārjuna and translated by the Tripițakadharmācārya Kumarājīva. Translated from French by Gelongma Karma Migme Chodron. Pleasant Bay, NS: Gampo Abbey. (http://promienie.net/images/dharma/books/nagarjuna_ mahaprajnaparamitasastra_vol-5.pdf, 05/11/2019).

Lamotte, Etienne (transl.): The Treatise on the Great Virtue of Wisdom of Nāgārjuna (Mahāprajñāpāramitāśāstra), Volume II, Chapters XVI - XXX, Composed by Bodhisattva Nāgārjuna and translated by the Tripițakadharmācārya Kumarājīva. Translated from French by Gelongma Karma Migme Chodron. Pleasant Bay, NS: Gampo Abbey.(http://elibrary.ibc. ac.th/files/public/Lamotte_Vol2_\%E5\%A4\%A7\%E6\%99\%BA\%E5\%BA\%A6\%E8\%AE\%BA\% E8\%8B\%B1\%E6\%96\%87.pdf, 04/11/2019).

Lidai minghua ji 歷代明畫記 = Zhang Yanyuan 張彥遠. Lidai minghua ji 歷代名畫記. In: Wenyuange siku quanshu 文淵閣四庫全書, vol. 812, pp. 227-356. Taibei: Taiwan Shangwu Yinshuguan, 2013. 
Liji = Liu Dianjue 劉殿爵 (D.C. Lau) / Chen Fangzheng 陳方正 (eds.) (1992): Liji zhuzi suoyin 禮記逐 字索引 [A Concordance to the Liji]. Taibei: Taiwan Shangwu Yinshuguan.

Ling Shu or The Spiritual Pivot. Tr. Wu Jing-nuan (Asian Spirituality, Taoist Studies Series). Washington DC: The Daoist Center/Honolulu: University of Hawai'i Press, 1993.

Lunheng = Liu Dianjue 劉殿爵 (D.C. Lau) / Chen Fangzheng 陳方正 (eds.) (1996): Lunheng zhuzi suoyin 論衡逐字索引 [A Concordance to the Lunheng]. Hong Kong: Shangwu Yinshuguan.

Lüshi Chunqiu = Liu Dianjue 劉殿爵 (D.C. Lau) / Chen Fangzheng 陳方正 (eds.) (1994): Lüshi Chunqiu zhuzi suoyin呂氏春秋逐字索引 [A Concordance to the Lüshichunqiu]. Taibei: Taiwan Shangwu Yinshuguan.

Major, John S. / QueenSarah A. / Meyer, Andrew Seth / Roth, Harold D. / Puett, Michael J. (transl. and ed.) (2010): The Huainanzi - A Guide to the Theory and Practice of Government in Early Han China. Liu An, King of Huainan. New York: Columbia University Press.

Pearson, Margaret J. (transl.) (1989): Wang Fu - A Study with Translations. Tempe: Center for Asian Studies, Arizona State University.

Qianfulun = Liu Dianjue 劉殿爵 (D.C. Lau) / Chen Fangzheng 陳方正 (eds.) (1995): Qianfulun zhuzi suoyin 潛夫論逐字索引 [A Concordance to the Qianfulun]. Taibei: Taiwan Shangwu Yinshuguan.

Qianzuodu = Yiwei Qianzuodu 易緯乾鳘度. In: Kōzan Yasui 安居 香山 / Nakamura Shōhachi 中村 璋八 (comp.) (1981): Chōshū isho shūsei 重修緯書集成, vol. 1A (Eki I, 易上). Tōkyō 東京: Meitoku Shuppansha 明德出版社, 17-68.

Queen, Sarah A. / Major, John S. (ed. and transl.) (2016): Luxuriant Gems of the Spring and Autumn - attributed to Dong Zhongshu. New York: Columbia University Press.

Rickett, W. Allyn (transl.) (1965): Kuan-tzu: A Repository of Early Chinese Thought. Vol. 1. Hong Kong: Hong Kong University Press.

Roth, Harold D. (1999): Original Tao: Inward Training (Nei-ye) and the Foundations of Taoist Mysticism. New York: Columbia University Press.

Shangshu = Liu Dianjue 劉殿爵 (D.C. Lau) / Chen Fangzheng 陳方正 (eds.) (1995): Shangshu zhuzi suoyin 尚書逐字索引 [A Concordance to the Shangshu]. Hong Kong: Shangwu Yinshuguan.

Shuoyuan = Liu Dianjue 劉殿爵 (D.C. Lau) / Chen Fangzheng 陳方正 (eds.) (1992): Shuoyuan zhuzi suoyin 說苑逐字索引 [A Concordance to the Shuoyuan]. Taibei: Taiwan Shangwu Yinshuguan.

Shuowen Jiezi = Shuowen Jiezi fu jian zi 說文解字付檢字 (1969): Hong Kong: Taiping Shuju 太平書局.

Sush $u=$ Huangshi Gong 黃石公. Sushu 素書. Beijing: Zhongguo Huabao 中國畫報, 2011.

Unschuld, Paul U. (transl.) (2015): Huang Di Nei Jing Ling Shu: Der vollständige chinesische Text mit kommentierter deutscher Übersetzung (Antike Klassiker der Chinesischen Medizin; 3). Berlin: Cygnus Verlag, 2015.

Unschuld, Paul U. (transl.) (2016): Huang Di Nei Jing Ling Shu: The Ancient Classic on Needle Therapy. Berkeley: University of California Press.

Wenfu = Lu Ji 陸機. Wenfu jishi 文賦集釋. Ed. by Zhang Shaokang 張少康. Shanghai: Shanghai Guji Chubanshe.

Wenxin diaolong = Liu Xie 劉諰. Wenxin diaolong 文心雕龍. Beijing: Renmin Chubanshe, 1998. Wenzi = Liu Dianjue 劉殿爵 (D.C. Lau) / Chen Fangzheng 陳方正 (eds.) (1992): Wenzi zhuzi suoyin 文子逐字索引 [A Concordance to the Wenzi]. Taibei: Taiwan Shangwu Yinshuguan. 
Xinshu = Liu Dianjue 劉殿爵 (D.C. Lau) / Chen Fangzheng 陳方正 (eds.) (1992): Jia Yi Xinshu zhuzi suoyin 賈誼新書逐字索引 [A Concordance to the Jia Yi xinshu]. Taibei: Taiwan Shangwu Yinshuguan.

Xunzi = Liu Dianjue 劉殿爵 (D.C. Lau) / Chen Fangzheng 陳方正 (eds.) (1996): Xunzi zhuzi suoyin 荷 子逐字索引 [A Concordance to the Xunzi]. Hong Kong: Shangwu Yinshuguan.

Yu Zhirong 於智榮 (ed., comm. and transl.) (2003): Jia Yi Xinshu 賈誼新書 (Ershi'er zi xiang zhu quan yi 二十二子詳注全譯). Ha'erbin 哈爾濱: Heilongjiang Renmin Chubanshe.

Yan Zhenyi 閻振益 / Zhong Xia 鍾夏 (ed. and comm.) (2007): Xinshu jiaozhu 新書校注 (Xin bian zhuzi jicheng 新編諸子集成). Beijing: Zhonghua Shuju.

Zhouli = Shisan jing zhu shu 十三經注疏, Vol. 3 (1973): Zhou li 周禮. Taibei: Yishu Yinshuguan 㙯 術引書館.

Zhuangzi = Liu Dianjue 劉殿爵 (D.C. Lau) / Chen Fangzheng 陳方正 (eds.) (2000): Zhuangzi zhuzi suoyin 莊子逐字索引 [A Concordance to the Zhuangzi]. Hong Kong: Shangwu Yinshuguan.

\section{Secondary Literature}

Barnwell, Scott A. (2013): "The Evolution of the Concept of De in Early China”. Sino-Platonic Papers 135: $1-83$.

Bauer, Wolfgang (2001): Geschichte der chinesischen Philosophie: Konfuzianismus, Daoismus, Buddhismus. Hg. Hans van Ess. München: C. H. Beck.

Baxter, William H. / Sagart, Laurent (2014): Old Chinese: A New Reconstruction. Oxford: Oxford University Press.

Behr, Wolfgang (2010): "Einleitende Bemerkungen zum Begriffsfeld Götter, Geister, Gespenster (China)". Presentation handout on a talk held at the Institute of East Asian Studies, University of Zurich, on 25 February 2010.

Behr, Wolfgang (2011): "Zhuangzis Weg: Eine Abschweifung”. In: Das Kamel und das Nadelöhr. Eine Begegnung zwischen Zhuangzi und Meister Eckhart. Edited by Hildegard Elisabeth Keller. Zürich: vdf Hochschulverlag, 41-59.

Behr, Wolfgang (2020): “Inscription Placement, Ineffability of Language and Discourses on Hiddenness: Marginalia on the Prehistory of Subtlety (wei) in Early China". In: Enthüllen und Verbergen in der Vormoderne / Revealing and Concealing in the premodern period. Edited by Henriette Hofmann, Barbara Schellewald, Sophie Schweinfurth, and Gerald Wildgruber. München: Fink.

Boltz, William G. / Schemmel, Matthias (2013): The Language of 'Knowledge' and 'Space' in the Later Mohist Canon (TOPOI - Towards a Historical Epistemology of Space). Berlin: MaxPlanck-Institut für Wissenschaftsgeschichte.

Brashier, Kenneth E. (2011): Ancestral Memory in Early China. Cambridge/London: Harvard University Press.

Bush, Susan (1983): “Tsung Ping's Essay on Painting Landscape and 'Landscape Buddhism of Mount Lu”. In: Theories of the Arts in China. Edited by Susan Bush and Christian Murck. Princeton, New Jersey: Princeton University Press, 132-164.

Bush, Susan (2004): “The Essay on Painting by Wang Wei (415-453) in context”. In: Chinese Aesthetics - The Ordering of Literature, the Arts, and the Universe in the Six Dynasties. Edited by Cai Zong-qi. Honolulu: University of Hawai'i Press, $60-80$. 
Cai, Zhong-qi (ed.) (2004): Chinese Aesthetics - The Ordering of Literature, the Arts, and the Universe in the Six Dynasties. Honolulu: University of Hawai'i Press.

Cai, Zong-qi (2004): "The Conceptual Origins and Aesthetic Significance of "Shen" in Six Dynasties Texts on Literature and Painting". In: Chinese Aesthetics - The Ordering of Literature, the Arts, and the Universe in the Six Dynasties. Edited by Cai Zong-qi. Honolulu: University of Hawai'i Press, 310-342.

Chang, Kwang-chih (1999): "China on the Eve of the Historical Period”. Ch. 1 of The Cambridge History of Ancient China - From the Origins of Civilization to 221 BC. Edited by Michael Loewe and Edward L. Shaughnessy. Cambridge: Cambridge University Press, 37-73.

Csikszentmihalyi, Mark (1997): "Chia l's "Techniques of the Tao" and the Han Confucian Appropriation of Technical Discourse". Asia Major, Third Series 10.1/2: 49-67.

de Bary, William Theodore et al. (1983): Sources of Chinese Tradition. New York: Coumbia University Press.

Dull, Jack L. (1966): A Historical Introduction to the Apocryphal (ch'an-wei) Texts of the Han Dynasty. Ph. D. Dissertation, University of Washington, Seattle.

Espesset, Grégoire (2018): “The Invention of Buddho-Taoism: Critical Historiography of a Western Neologism, 1940s-2010s”. Asiatische Studien/Études Asiatiques 72.4: 1059-1098.

Fan Mingji 藩銘基 (2019): “Lun Jia Yi 'yong liu’ sixiang zhi yuanyuan - jianlun 'Liu shu’ 'Dao de shuo’ zhi chengpian niandai” 論賈誼 ‘用六’ 思想之淵源 一 兼論《六術》《道德說》之成篇 年代. Zhuzi Xuekan 諸子學刊 14: 161-183.

Gassmann, Robert / Behr, Wolfgang (2013): Grammatik des Antikchinesischen: Begleitband zu Antikchinesisch - Ein Lehrbuch in zwei Teilen. Bern/Berlin: Peter Lang Verlag.

Gong, Huanan (2017): "Senses and Cognition in Early Chinese Thought". Social Sciences in China 38.4: 28-44.

Graham, Angus Charles / Sivin, Nathan (1973): “A Systematic Approach to the Mohist Optics (ca. 300 B.C.)". In: Chinese Science - Explorations of an Ancient Tradition. Edited by Shigeru Nakayama and Nathan Sivin. Cambridge, Massachusetts/London: The MIT Press, 105-152.

Graham, Angus Charles (1978): Later Mohist Logic, Ethics and Science. Hong Kong: Chinese University Press.

Greene, Eric M. (2018): “The 'Religion of Images’? Buddhist Image Worship in the Early Medieval Chinese Imagination". Journal of the American Oriental Society 138.3: 455-484.

Guwenzi gulin bianzuan weiyuanhui 古文字詁林編纂委員會 (1999-2004): Guwenzi gulin 古文字詁林. Shanghai: Shanghai Jiaoyu Chubanshe.

Harbsmeier, Christoph (1998): Language and Logic (Science and Civilisation in China, vol. 7.1). Cambridge: Cambridge University Press.

Hügli, A. (2004): “Wert, I. Einleitung”. Historisches Wörterbuch der Philosophie. Hgg. Joachim Ritter, Karlfried Gründer, Gottfried Gabriel. Bd. 12. Darmstadt: Wissenschaftliche Buchgesellschaft, 556-558.

Kohn, Livia (2008): “cun 存 visualization, actualization”. In: The Encyclopedia of Taoism, vol. 1 A-L. Ed. by Fabrizio Pregadio. London: Routledge.

Krause, Carsten (2003): Das Ch'eng-shih-lun: Aufnahme und Wirkung eines buddhistischen Textes im mittelalterlichen China von Kumārajīva (343-413) bis Chi-tsang (549-623). Doctoral Dissertation, University of Hamburg.

Laufer, Berthold (1915): “Optical Lenses”. T’oung Pao 16: 169-228.

Ledderose, Lothar (1983): "The Earthly Paradise: Religious Elements in Chinese Landscape Art". In: Theories of the Arts in China. Edited by Susan Bush and Christian Murck. Princeton, New Jersey: Princeton University Press, 165-183. 
Liebenthal, Walter (1952): “The Immortality of the Soul in Chinese Thought”. Monumenta Nipponica 8.1/2: 327-397.

Loehr, Max (1962): “The Birth of Landscape Painting in China. By Michael Sullivan. Pp. xvii + 213, 72 drawings, 149 illustrations. Berkeley and Los Angeles: University of California Press. Book Review". Journal of the American Oriental Society 82.2: 257-262.

Mai Lai-man 梅迺文 [Mei Naiwen] (1996): “Zhu Fahu de fanyi chutan 竺法護的翻譯初探 (A Tentative Study of the Translation works of Master Dharmarakșa)”. Zhonghua Foxue Xuebao 中華佛學學報 (Chung-Hwa Buddhist Journal) 9: 49-64.

Mair, Victor H. (2004): “Xie He's "Six Laws" of Painting and Their Indian Parallels". In: Chinese Aethetics: The Ordering of Literature, the Arts, and the Universe in the Six Dynasties. Edited by Cai, Zong-qi. Honolulu: University of Hawai'i Press, 81-122.

Murray, Judson B. (2016): ““'Only Jade Can Epitomize Human Virtue”: Ideas on Education and Moral Development in Han-Period China". Asia Major, Third Series 29.2: 73-114.

Nylan, Michael (2008): “Beliefs about Seeing: Optics and Moral Technologies in Early China”. Asia Major 21.1: 81-132.

Obert, Mathias (2000): "Vom Nutzen und Vorteil der Bildbetrachtung: Zong Bings Theorie der Landschaftsmalerei”. Asiatische Studien/Études Asiatiques 54.4: 839-874.

Park, Jungnok (2012): How Buddhism Acquired a Soul on the Way to China (Oxford Centre for Buddhist Studies Monograph). Sheffield/Bristol: Equinox Publishing Ltd.

Pfister, Rudolf (2012): “Phosphenes and Inner Light Experiences in Medieval Chinese Psychophysical Techniques. An Exploration”. In: Concepts and Categories of Emotion in East Asia. Edited by Giusi Tamburello. Roma: Carocci editore, 38-70.

Pulleyblank, Edwin G. (1991): "Some Notes on Morphology and Syntax in Classical Chinese". In: Chinese Texts and Philosophical Contexts - Essays Dedicated to Angus C. Graham. Edited by Henry Rosemont, Jr. La Salle, IL: Open Court, 21-45.

Purtle, Jennifer (2018): "Double Take: Chinese Optics and their Media in Postglobal Perspective". Ars orientalis 48: 71-117.

Radich, Michael (2014): "Ideas about "Consciousness" in Fifth and Sixth Century Chinese Buddhist Debates on the Survival of Death by the Spirit, and the Chinese Background to *Amalavijñāna”. In: A Distant Mirror - Articulating Indic Ideas in Sixth and Seventh Century Chinese Buddhism. Edited by Chen-kuo Lin and Michael Radich. Hamburg: Hamburg University Press, 471-512.

Schuessler, Axel (2009): Minimal Old Chinese and Later Han Chinese - A Companion ot the Grammata Serica Recensa. Honolulu: University of Hawai'i Press.

Shaw, Miranda (1988): “Buddhist and Taoist Influences on Chinese Landscape Painting”. Journal of the History of Ideas 49.2: 183-206.

Soothill, William Edward / Hodous, Lewis (1937): A Dictionary of Chinese Buddhist Terms. London: Kegan Paul, Trench, Trubner and Co.

Sullivan, Michael (1962): The Birth of Landscape Painting in China. Berkeley/Los Angeles: University of California Press.

Svarverud, Rune (1998): Methods of the Way: Early Chinese Ethical Thought (Sinica Leidensia; 43). Leiden/Boston/Köln: Brill.

Tian Tan 田探 (2013): “Lun Jia Yi de ‘Dao de shuo’ yu ‘xing ming’ lun - jianlun Jia Yi yi ‘li’ wei ben dui ruxue de chonggou 論賈誼的 “道德說” 與 “性命”論 — 兼論賈誼以 “理” 爲本對儒學的重構. Qiu suo 求索 2012: 76-79.

Tian, Xiaofei (2005): “Seeing with the Mind's Eye: The Eastern Jin Discourse of Visualization and Imagination”. Asia Major, Third Series 18.2: 67-102. 
Turner, Matthew (2009): “Classical Chinese Landscape Painting and the Aesthetic Appreciation of Nature”. Journal of Aesthetic Education 43.1: 106-121.

Unschuld, Paul U. (2003): Huang Di Nei Jing Su Wen: Nature, Knowledge, Imagery in an Ancient Chinese Medical Text. With an Appendix, The Doctrine of the Five Periods and Six Qi in the Huang Di Nei Jing Su Wen. Berkeley: University of California.

Wu, Ling-An / Gui, Lu Lung / Gong, Qihuang / Guo, Guang-Can (2015): “Optics in Ancient China”. Facts and info of the European Physical Society, http://www.epsnews.eu/2015/10/optics-inancient-china/ (last accessed, 19-11-2019). 